\title{
8. SILICOFLAGELLATES AND EBRIDIANS FROM LEG 138, EASTERN EQUATORIAL PACIFIC ${ }^{1}$
}

\author{
Kevin McCartney, ${ }^{2}$ Sherry Churchill, ${ }^{2}$ and Linda Woestendiek ${ }^{2}$
}

\begin{abstract}
The biostratigraphic distribution and abundance of middle Miocene to Pleistocene silicoflagellates is documented from Ocean Drilling Program (ODP) Leg 138 Holes 844B, 847B, 848B, 849B, 850B, 851B, 852B, and 854B from the eastern Equatorial Pacific Ocean. The silicoflagellates were generally abundant and well preserved and frequently exhibited an unusually large range of variation. The upper Miocene of near-equatorial sites includes an assemblage of Bachmannocena diodon nodosa, which includes a bridge across the width of the basal ring. Stratigraphically below this, at sites within $5^{\circ}$ of the equator is a lengthy interval of specimens of Distephanus speculum tenuis, which have a fragile apical structure. Both the intervals of Bachmannocena diodon nodosa plexus and Distephanus speculum tenuis are biostratigraphically useful within $5^{\circ}$ of the equator, but are less useful beyond that. An unusual range of variation also is observed for Dictyocha in the Pliocene sediments at about the point where D. perlaevis and $D$. messanensis appear in the geologic record. This variation may be explained by hybridization between diverging species.
\end{abstract}

\section{INTRODUCTION}

Eleven sites were drilled in the eastern Equatorial Pacific Ocean during Ocean Drilling Program (ODP) Leg 138 in May and June, 1991. These sites were chosen so as to sample each of the major oceanographic features of the equatorial current system (Fig. 1 and Table 1). The sites are divided into two complementary north-south transects. The western transect is centered at about $110^{\circ} \mathrm{W}$ and was chosen to provide information about the equatorial circulation system in an area far removed from the influence of the eastern boundary of the Pacific Ocean. Sites of the eastern transect occur $15^{\circ}$ to $20^{\circ}$ to the east and, thus, are located closer to Central and South America.

Leg 138 is the fifth ODP expedition to examine the evolution of global climate change during the late Cenozoic using high-resolution analyses of deep-sea sediments. During previous legs, the equatorial Atlantic (Leg 108), the Peru Current (Leg 112), the western tropical Pacific Ocean (Leg 130), and the northwestern Indian Ocean (Leg 117) were sampled; of these, only Leg 112 (Martini, 1990) included published work on silicoflagellates. The paucity of silicoflagellate studies associated with these legs does not reflect an absence of silicoflagellates, which are exceptionally abundant and diverse in tropical waters, but reflects the limited number of silicoflagellate specialists. Silicoflagellate studies from equatorial sites published in Initial Reports from the Deep Sea Drilling Project (DSDP) and ODP are summarized in Table 2.

This report documents the biostratigraphic occurrence and abundance of silicoflagellates from Holes 844B, 847B, 848B, 849B, 850B, $851 \mathrm{~B}, 852 \mathrm{~B}$ and $854 \mathrm{~B}$. Silicoflagellates generally occur throughout the continuous stratigraphic sequence, although samples examined from Hole 854B were barren of silicoflagellates in the Miocene interval. Samples from nearer the equator have silicoflagellate assemblages, showing unusual skeletal variability, that are less abundant or not found in holes located farther from the equator (Hole 845B, 854B). Morphological variation among the four-sided Dictyocha, with bridges parallel to the major axis, is also extraordinary, as numerous intermediate morphotypes occur between several well-known morphotaxonomic end-members.

Other minor siliceous microfossil groups also occur in the Leg 138 samples. Endoskeletal dinoflagellates, particularly Actiniscus, are fre-

${ }^{1}$ Pisias, N.G., Mayer, L.A., Janecek, T.R., Palmer-Julson, A., and van Andel, T.H (Eds.), 1995. Proc. ODP, Sci. Results, 138: College Station, TX (Ocean Drilling Program).

${ }_{2}$ Micropaleontology Undergraduate Research Laboratory, University of Maine at Presque Isle, Presque Isle, ME 04769, U.S.A. quently abundant, while ebridians and siliceous sponge spicules are generally rare; ebridian occurrences are tabulated in this study for Holes 844B, 848B, 850B and 851B.

\section{SAMPLE PREPARATION}

Samples used in this study are the same as those used for diatom investigations (Baldauf and Iwai, this volume). Raw samples were prepared as smear slides with a $22-/ 50-\mathrm{mm}$ cover slip. Where silicoflagellates were abundant, 300 specimens were counted, and the approximate amount of the slide required to find that many specimens is recorded in the abundance charts (Tables 3 through 10). Each tenth of a slide examined represents approximately $1.1 \mathrm{~cm}^{2}$; the relative abundance of any two slides can be obtained by dividing the total count by the area of each slide examined. In most cases, where silicoflagellates were less abundant, the whole slide was examined, although sometimes less than a whole slide was counted when silicoflagellates were extremely rare or when only a brief examination was needed to more precisely place zonal boundaries. Less than 300 counts were made in some cases, where the slide was difficult to examine or where silicoflagellates were scarce.

Only those fragments representing more than one-half of a silicoflagellate were included in the counts. A separate tally has been made of teratoid (aberrant) specimens because these may be an indication of environmental stress. Common aberrant skeletons included those having deformed or incomplete basal rings, multiple spines on a basal corner, or multiple struts to a side (see McCartney and Loper, 1989 , for a discussion of the basic rules of silicoflagellate form). Because aberrants are often counted among the specific taxa, the number of aberrants was not included in the total counts.

Parts of this study were conducted by undergraduate students having limited experience of silicoflagellates. These students had a year of training and were closely supervised by the first author. Because of the complexity of silicoflagellate taxonomy and variability, the relative inexperience of these students' work should be taken into account when evaluating this study. Because this study is the work of three microscopists, there can be variations in species concept from one hole to another. Sherry Churchill conducted the census for Holes 849B and 852B; Linda Woestendiek performed the microscope work for Holes $844 \mathrm{~B}$ and $847 \mathrm{~B}$.

\section{SILICOFLAGELLATE ZONATION}

A number of low-latitude silicoflagellate zonations have been previously proposed (Bukry, 1979a, 1981a, 1981b, 1982a, 1983, 1985; Locker and 


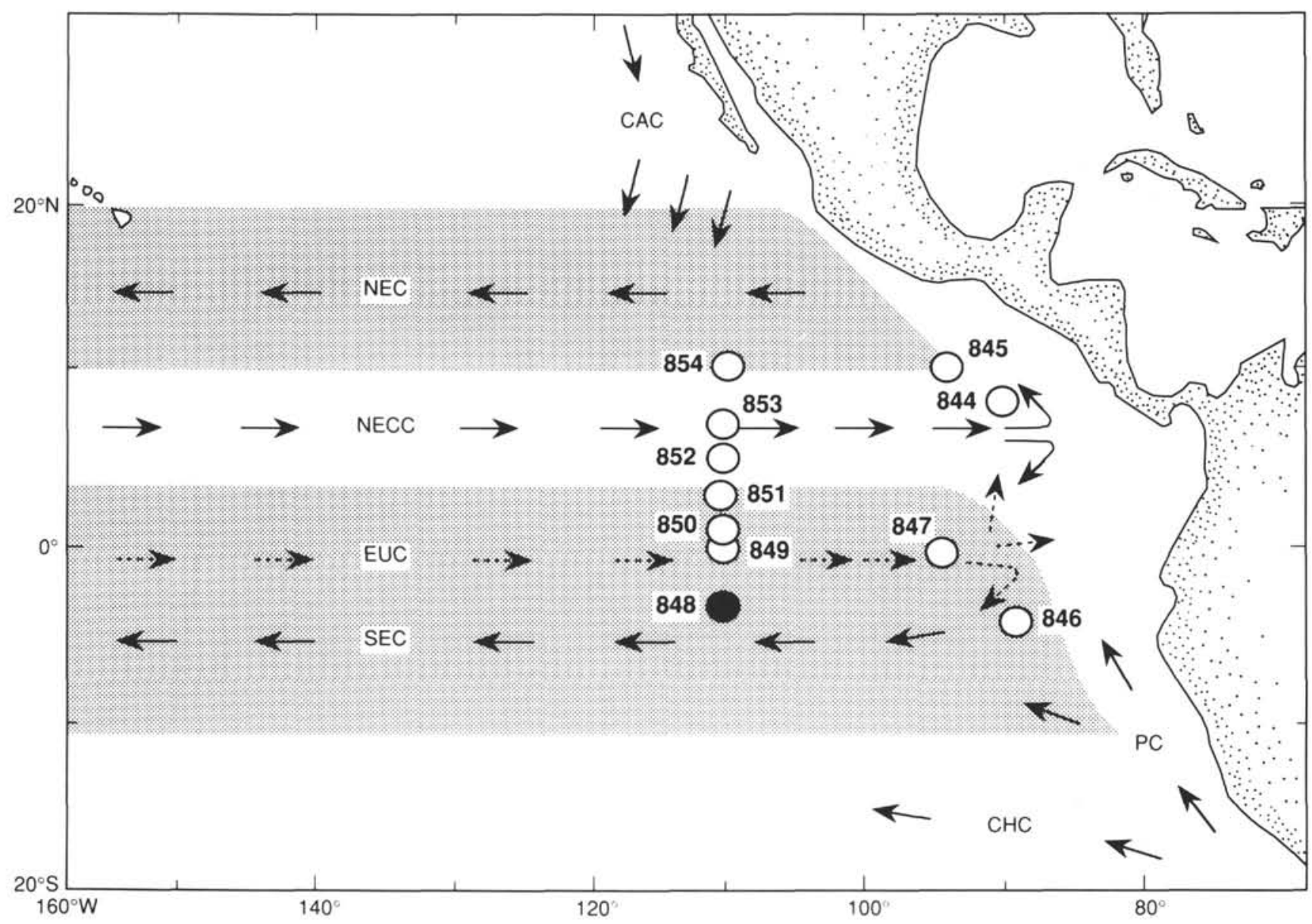

Figure 1. Location map showing sites drilled during Leg 138. $\mathrm{CAC}=\mathrm{California}$ Current; $\mathrm{CHC}=$ Chile Current; $\mathrm{NEC}=\mathrm{North}$ Equatorial $\mathrm{Current}$; $\mathrm{NECC}=$ North Equatorial Countercurrent; EUC = Equatorial Undercurrent; $\mathrm{SEC}=$ South Equatorial Current; $\mathrm{PC}=$ Peru Current.

Martini, 1986b; Martini, 1990). These zonations tend to be similar for the Pleistocene and late Pliocene, but differ widely for the early Pliocene and Miocene. Our study shows that some taxa, such as Distephanus speculum tenuis and Bachmannocena diodon nodosa, are narrowly restricted latitudinally, suggesting that several zonations may be required to subdivide sequences stratigraphically in the tropical regions.

Here, horizons are used for biostratigraphic intervals that are short enough that they may be missed at a sample interval of approximately $5 \mathrm{~m}$ (Fig. 2). Although these intervals are biostratigraphically useful, their brief duration often prevents their consistent discovery at all sites at the sample interval used in this study. The usage here differs from Bukry (e.g., 1985), who used taxa that are abundant in brief intervals as subzones.

\section{Corbisema triacantha Range Zone}

Definition: Interval from the last occurrence of Naviculopsis species to last occurrence of $C$. triacantha.

Author: Martini (1971).

Common species: Common species include Dictyocha varia, D. extensa, D. fibula fibula, D. fibula ausonia, and Distephanus crux. Distephanus stauracanthus is scattered and can be common in the upper part of this zone.

Remarks: This zone was found only in Hole 844B, and includes two horizons. The Distephanus stauracanthus Horizon has been described by Martini (1972), and Locker and Martini (1986b), and occurred over an interval of about $50 \mathrm{~m}$ in Hole 844B; despite its thickness it is here considered as a horizon because we are uncertain of its geographic distribution and because of its usage as a horizon by previous workers. The horizon extends from the first to the last appearance of the nominate taxon. Near the bottom of Hole 844B is the Dictyocha varia (deflandroid) Acme Horizon, in which deflandroid variants of $D$. varia and $D$. extensa are abundant. These horizons are discussed in greater detail by Woestendiek and McCartney (this volume).
Table 1. Details of Leg 138 holes examined for silicoflagellates in this study.

\begin{tabular}{cccrrr}
\hline Hole & $\begin{array}{c}\text { Latitude } \\
\left({ }^{\circ} \mathrm{N} \text { or S }\right)\end{array}$ & $\begin{array}{c}\text { Longitude } \\
\left({ }^{\circ} \mathrm{W}\right)\end{array}$ & $\begin{array}{c}\text { Water } \\
\text { depth } \\
(\mathrm{m})\end{array}$ & $\begin{array}{c}\text { Cored } \\
(\mathrm{m})\end{array}$ & $\begin{array}{c}\text { Recovery } \\
(\%)\end{array}$ \\
\hline $844 \mathrm{~B}$ & $07^{\circ} 55,279^{\prime} \mathrm{N}$ & $90^{\circ} 28.846^{\prime}$ & 3414.5 & 290.0 & 99 \\
$847 \mathrm{~B}$ & $00^{\circ} 11.593^{\prime} \mathrm{N}$ & $95^{\circ} 19.227^{\prime}$ & 3334.3 & 247.0 & 98 \\
$848 \mathrm{~B}$ & $02^{\circ} 59.634^{\prime} \mathrm{S}$ & $110^{\circ} 28.791^{\prime}$ & 3855.6 & 93.8 & 104 \\
$849 \mathrm{~B}$ & $00^{\circ} 10.983^{\prime} \mathrm{N}$ & $110^{\circ} 31.183^{\prime}$ & 3855.6 & 350.5 & 98 \\
$850 \mathrm{~B}$ & $01^{\circ} 17.827^{\prime} \mathrm{N}$ & $110^{\circ} 31.286^{\prime}$ & 3786.3 & 398.8 & 99 \\
$851 \mathrm{~B}$ & $02^{\circ} 46.223^{\prime} \mathrm{N}$ & $110^{\circ} 34.308^{\prime}$ & 3760.3 & 320.5 & 99 \\
$852 \mathrm{~B}$ & $05^{\circ} 17.566^{\prime} \mathrm{N}$ & $110^{\circ} 04.579^{\prime}$ & 3859.9 & 113.4 & 105 \\
$854 \mathrm{~B}$ & $11^{\circ} 13.433^{\prime} \mathrm{N}$ & $109^{\circ} 35.652^{\prime}$ & 3567.4 & 45.4 & 105 \\
\hline
\end{tabular}

\section{Dictyocha varia Interval Zone}

Definition: The bottom of this zone is defined as the last occurrence of Corbisema triacantha Acme. The top of this zone is defined as the first occurrence of $D$. speculum temuis; where $D$. speculum tenuis does not occur, as happens at locations farther from the equator, the top of this zone is defined as the first consistent occurrence of Dictyocha extensa.

Author: Modified from Locker and Martini (1986b).

Common species: Dictyocha varia is generally the dominant species with Distephanus speculum speculum as a secondary species. Dictyocha extensa is usually present and can be abundant, particularly near the top of the zone, such as in Samples 138-850B-28X-1, 120-121 cm, and 138-851B-20X-1, 120-121 $\mathrm{cm}$. D. fibula fibula, D. fibula ausonia, and Distephanus crux are scattered. Dictyocha subclinata occurs in a narrow horizon (see remarks below).

Remarks: The overall diversity of silicoflagellate species is low, especially in the lower part of this zone. This zone includes the Dictyocha subclinata Horizon, which is found in Samples 138-850B-33X-1, 120-121 cm, and $-851 \mathrm{~B}-25 \mathrm{X}-1,120-121 \mathrm{~cm}$. 
Table 2. Silicoflagellate studies from equatorial sites $\left(<25^{\circ}\right)$.

\begin{tabular}{|c|c|c|c|c|c|c|c|c|}
\hline $\begin{array}{c}\text { Leg } \\
\text { (Sites) }\end{array}$ & Pleistocene & Pliocene & Miocene & Oligocene & Eocene & Paleo. & Cretaceous & Reference \\
\hline \multirow{13}{*}{$\begin{array}{l}7(65-66) \\
13(124-128) \\
16(157-158) \\
22(216) \\
33(315-316) \\
34(329-321) \\
39(354) \\
40(362) \\
54(419-428) \\
63(471) \\
67(495) \\
68(503) \\
69(504) \\
78(543) \\
85(572,575) \\
112(682-688)\end{array}$} & $X$ & $\mathrm{X}$ & $x$ & \multirow{11}{*}{$\underset{\mathrm{X}}{\mathrm{X}}$} & & & \multirow{13}{*}{$\mathrm{X}$} & \multirow{13}{*}{$\begin{array}{l}\text { Martini, 1971 } \\
\text { Dumitrica, 1972 } \\
\text { Bukry and Foster, } 1973 \\
\text { Bukry, 1974 } \\
\text { Martini, 1976 } \\
\text { Bukry, 1976b } \\
\text { Perch-Nielsen, } 1977 \\
\text { Bukry, 1978c } \\
\text { Bukry, 1980 } \\
\text { Bukry, 1981a } \\
\text { Bukry, 1982a } \\
\text { Bukry, 1982b } \\
\text { Bukry, 1983 } \\
\text { Bukry, 1984 } \\
\text { Bukry, 1985 } \\
\text { Martini, 1990 }\end{array}$} \\
\hline & $\mathrm{X}$ & $\widehat{x}$ & $x$ & & & & & \\
\hline & $\mathrm{X}$ & $\mathrm{X}$ & $\mathrm{U}, \mathrm{M}$ & & & & & \\
\hline & $\mathrm{X}$ & $x$ & $X$ & & & & & \\
\hline & $\hat{x}$ & $\hat{\mathrm{U}}$ & & & & & & \\
\hline & & & & & & & & \\
\hline & $\underset{y}{X}$ & $\underset{\mathrm{X}}{\mathrm{X}}$ & $X$ & & & & & \\
\hline & $x$ & $x$ & & & & & & \\
\hline & X & $X$ & $\mathrm{U}$ & & & & & \\
\hline & & $\hat{x}$ & $\hat{U}$ & & & & & \\
\hline & $X$ & $\mathrm{X}$ & U & & & & & \\
\hline & & & $\stackrel{\mathrm{L}}{\mathrm{X}}$ & \multirow{2}{*}{$x$} & & & & \\
\hline & $\mathrm{X}$ & $\hat{x}$ & $\hat{x}$ & & & & & \\
\hline
\end{tabular}

Notes: Only publications with charts that show relative or absolute abundances are listed here. $\mathrm{X}=$ present throughout the series; $\mathrm{U}, \mathrm{M}$. $\mathrm{L}=$ subseries.

Distephanus speculum tenuis Range Zone

Definition: Interval from the first to last common occurrence of Distephanus speculum tenuis.

Author: McCartney, Churchill and Woestendiek (this paper).

Common species: The dominant species is usually Dictyocha extensa; $D$. varia is much less abundant within this zone than in the intervals immediately above and below it. Other important species are $D$. speculum speculum, $D$, fibula fibula, and D. fibula ausonia.

Remarks: This zone occurs over a thick sediment interval and has abundant $D$. speculum tenuis only at locations near the equator.

\section{Dictyocha extensa Interval Zone}

Definition: Interval from the last common occurrence of Distephanus speculum tenuis to the first common occurrence of Dictyocha messanensis.

Author: McCartney, Churchill and Woestendiek (this paper).

Common species: Dictyocha fibula, D. varia, and Distephanus speculum are generally present, and the Bachmannocena diodon nodosa assemblage is abundant in a narrow horizon near the bottom of this zone (see remarks below).

Remarks: The Dictyocha extensa Zone includes two horizons. The first of these, the Distephanus xenus Horizon, was not found in holes examined as part of this study, but occurs in Hole 849B and Hole 847B. The Bachmannocena diodon nodosa assemblage Horizon occurs near the bottom of this zone. It is most pronounced near the equator and rapidly thins beyond a latitude of $5^{\circ} \mathrm{N}$ and $5^{\circ} \mathrm{S}$. This horizon is much less pronounced at sites studied from the eastern transect, suggesting that it may be severely restricted geographically. We consider this interval as a horizon, rather than a zone, because it could not be consistently found in all Leg 138 holes.

\section{Dictyocha messanensis Partial Range Zone}

Definition: Interval from the last common occurrence of Dictyocha extensa to the first common occurrence of Bachmannocena quadrangula.

Author: Bukry (1981b), as the Dictyocha stapedia stapedia Zone.

Common species: Dictyocha perlaevis, Distephanus speculum, with scattered Distephanus pulchra. A wide variety of Dictyocha cannot be easily placed into established species and are here listed as Dictyocha $\mathrm{sp}$.

Remarks: In Holes 850B and -851B, the dominant silicoflagellate group is often what is here listed as Dictyocha sp. North and south of these holes, the occurrence of this group declines markedly, and silicoflagellate are more easily placed into the established taxonomy.

\section{Bachmannocena quadrangula Range Zone}

Definition: Interval from the first common to last common occurrence of Bachmannocena quadrangula.

Author: Described by Bukry and Foster (1973) as Mesocena elliptica Zone (see Bukry, 1979b).

Common species: Dictyocha perlaevis and D. messanensis; Distephanus pulchra also occur with the nominate species.

Remarks: Bachmannocena quadrangula is dominant in a narrow interval. Locker and Martini (1986b) considered this interval as a horizon, but we found it throughout the Leg 138 study area and thick enough to be found at a sample interval of two samples per core (approximately $5 \mathrm{~m}$ ); thus, we follow the usage of Bukry (1979b, 1981b), who used it as a zone. The zones above and below

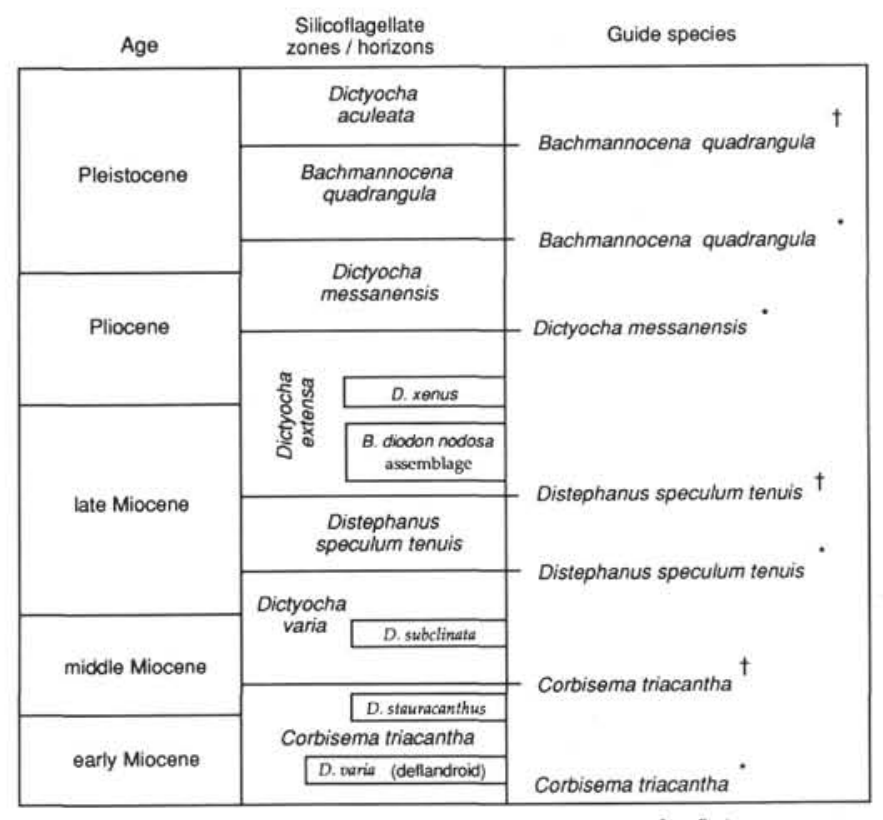

$\cdot=$ first appearance

$t=$ last appearance

Figure 2. Silicoflagellate zonation used for Leg 138.

this interval would be difficult to divide consistently without the use of Bachmannocena quadrangula as a boundary between the zones.

\section{Dictyocha aculeata Interval Zone}

Definition: Interval from the last common occurrence of the Bachmannocena quadrangula at the zone base; the top is not defined.

Author: Bukry (1981b).

Common species: Dictyocha perlaevis and D. messanensis; Distephanus pulchra is scattered.

Remarks: This zone is best exhibited in Hole 849B, where an extended sequence contains abundant $D$. aculeata. In Holes $850 \mathrm{~B}$ and $-851 \mathrm{~B}$, Dictyocha aculeata and $D$. subaculeata are less common than $D$. perlaevis and $D$. messanensis. The relative abundance of $D$. perlaevis varies considerably.

\section{SITE SUMMARIES}

\section{Site 844}

Site 844 is located in the Guatemala Basin of the eastern equatorial Pacific Ocean within the eastward-flowing North Equatorial Countercurrent (see Fig. 1). It lies in the region of the Costa Rica Dome, in which wind-induced doming of the thermocline produces surface upwelling and high open-ocean productivity, and of the Leg 138 sites 
Table 3. Abundance of silicoflagellates and ebridians in selected samples from Hole 844B.

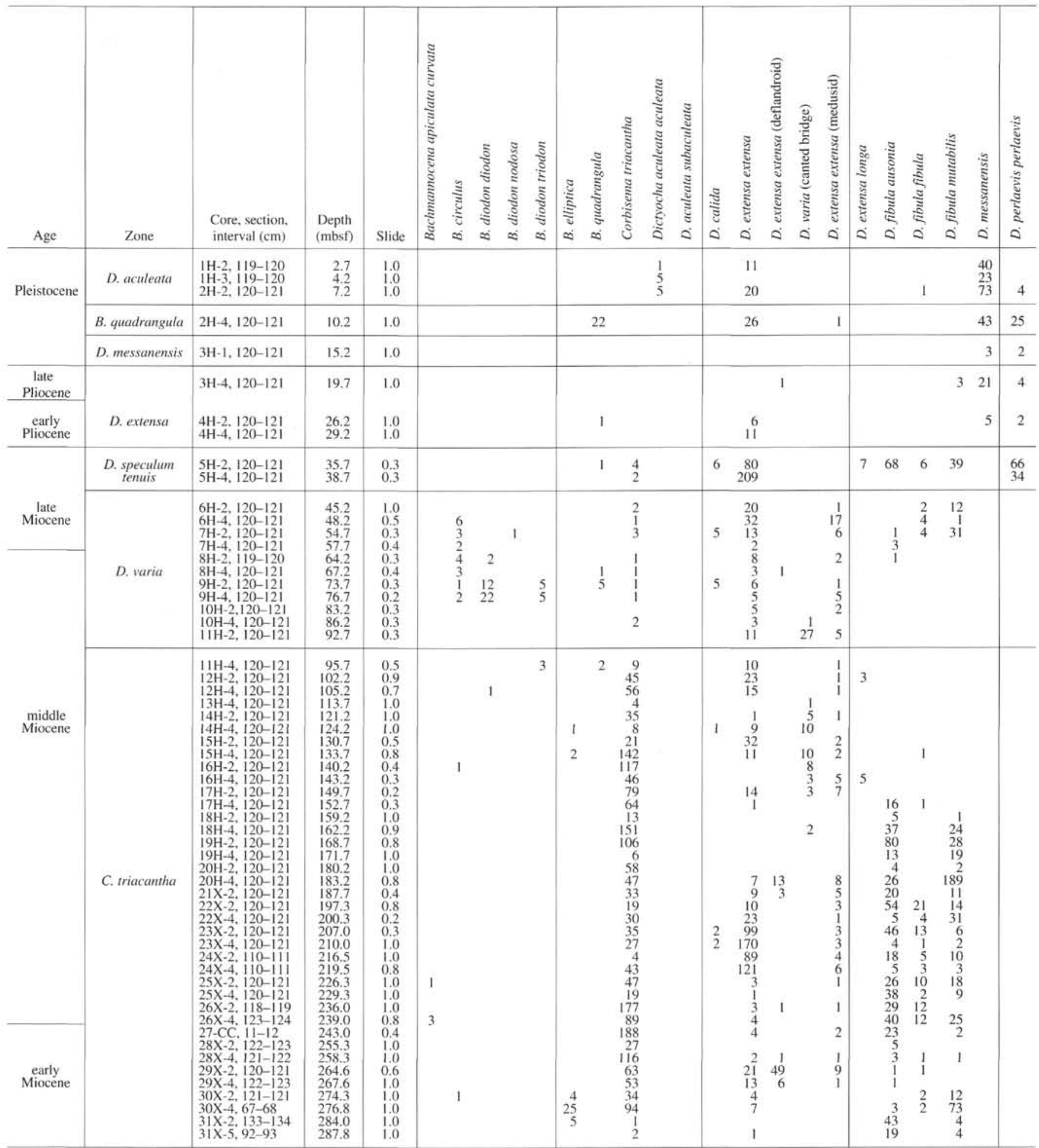

Notes: Species (in alphabetical order) are recorded as total number of specimens found in the slides examined.

is the one closest to a major landmass. This hole is noteworthy for a lengthy middle and upper Miocene interval (Table 3).

Four holes were drilled at this site to assure continuous recovery and to provide sufficient volume of material for high-resolution analyses. Study of magnetic susceptibility and GRAPE-measured sediment density show that Holes $844 \mathrm{~B}$ through $844 \mathrm{D}$ recovered a continuous sequence of the upper $185 \mathrm{~m}$ of the section. Three lithologic units are recognized. Unit I ( $0-22$ mbsf; Pliocene-Pleistocene) is a clay-rich biogenic silica ooze with little carbonate. Unit II (22-74.9 mbsf; late early Miocene to late Miocene) is an alternating carbonate and silica-rich biogenic ooze. Unit III (74.9-291 mbsf; late early Miocene to late Miocene) has varying lithologies dominated by biogenic calcium carbonate. Samples from Hole 844B, which was cored with the APC to $185 \mathrm{mbsf}$, then with the XCB to basement at 291 mbsf, were examined for silicoflagellates.

Silicoflagellates from Hole 844B showed marked similarities in a lack of abundance, when compared with other Leg 138 sites in the late Pleistocene Dictyocha aculeata Zone (Fig. 3 and Table 3). They do 
TABLE 3 (continued).

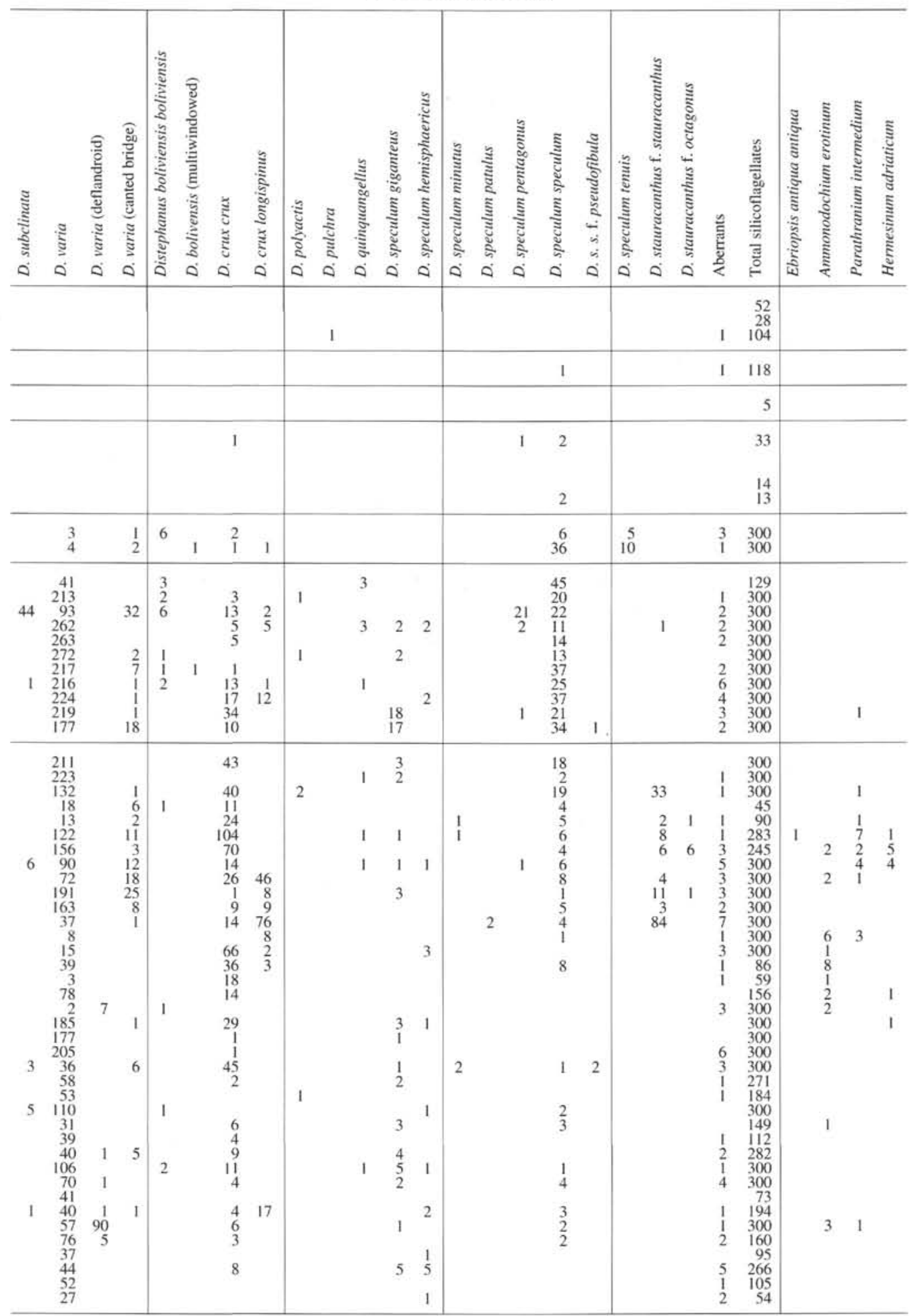

not become more abundant until Sample 138-844B-5H-2, 120-121 $\mathrm{cm}$, in the end of the late Miocene, where they appear to have had one last population surge before dwindling.

Silicoflagellates are generally not abundant in the Pleistocene and Pliocene, with the total number of silicoflagellates on a microscope slide frequently less than 50 specimens. Dictyocha aculeata are uncommon within the Dictyocha aculeata Zone; this taxon is especially abundant near the equator and the relative abundance declines toward higher latitudes. The Bachmannocena quadrangula Zone is represented by 22 specimens in Sample 138-844B-11H-2, 120-121 cm.
Both the Dictyocha messanensis and the D. extensa zones are very short when compared to other Leg 138 holes.

The Bachmannocena diodon nodosa plexus was not discovered in Hole $844 \mathrm{~B}$. This horizon thins rapidly away from the equator; if it occurs at all in Hole 844B it must be thinner than the approximately $5-\mathrm{m}$ sample interval used in this hole. The Distephanus speculum tenuis Zone is found only in Samples 138-844B-5H-2, 120-121 cm, and -5H-4, 120$121 \mathrm{~cm}$, although specimens of the nominative taxon are uncommon.

The Corbisema triacantha Zone makes up almost two-thirds of the Hole 844B interval. The top of this zone is placed in Sample 


\begin{tabular}{|c|c|c|c|c|c|c|c|c|c|}
\hline Age & $\begin{array}{c}\text { Silicoflagellate } \\
\text { zones / horizons }\end{array}$ & $\begin{array}{l}\text { Hole } \\
844 \mathrm{~B}\end{array}$ & $\begin{array}{l}\text { Hole } \\
847 B\end{array}$ & $\begin{array}{l}\text { Hole } \\
848 B\end{array}$ & $\begin{array}{l}\text { Hole } \\
8498\end{array}$ & $\begin{array}{l}\text { Hole } \\
8508\end{array}$ & $\begin{array}{l}\text { Hole } \\
851 B\end{array}$ & $\begin{array}{l}\text { Hole } \\
8528\end{array}$ & $\begin{array}{l}\text { Hole } \\
854 \mathrm{~B}\end{array}$ \\
\hline \multirow{2}{*}{$\begin{array}{l}\text { Pleisto- } \\
\text { cene }\end{array}$} & $\begin{array}{l}\begin{array}{c}\text { Dictyocha } \\
\text { aculeata }\end{array} \\
\end{array}$ & $\begin{array}{l}1 \mathrm{HH}-1 \\
t \mathrm{0} \\
2 \mathrm{H}-2 \\
\end{array}$ & $\begin{array}{c}\mathrm{IH}-1 \\
\text { to } \\
3 \mathrm{H}-4 \\
\end{array}$ & $\begin{array}{c}1 H+1 \\
\text { to } \\
2 H-4 \\
\end{array}$ & $\begin{array}{l}1+1+1 \\
\text { to } \\
3 H+1 \\
\end{array}$ & $1 \mathrm{H}-1$ & $\begin{array}{c}1 \mathrm{H}-1 \\
\text { to } \\
2 \mathrm{H}-1 \\
\end{array}$ & $1 \mathrm{H}-1$ & ${ }^{H H-1}$ \\
\hline & $\begin{array}{c}\text { Bachmannocena } \\
\text { quadrangula }\end{array}$ & $2 \mathrm{H}-4$ & $\begin{array}{c}4 \mathrm{H}-4 \\
\text { to } \\
5 \mathrm{H}-4 \\
\end{array}$ & $\begin{array}{c}3 \mathrm{HH} \\
\text { to } \\
3 \mathrm{H}-4\end{array}$ & $\begin{array}{c}3 \mathrm{HH}-4 \\
\text { to } \\
4 \mathrm{HH}-4\end{array}$ & $\begin{array}{c}2 \mathrm{H}-4 \\
\text { to } \\
3 \mathrm{H}-1\end{array}$ & $3 \mathrm{H}-1$ & $2 \mathrm{H}-1$ & $1 \mathrm{H}-4$ \\
\hline \multirow[t]{2}{*}{ Pliocene } & $\begin{array}{c}\text { Dictyocha } \\
\text { messanensis }\end{array}$ & $\begin{array}{c}3 \mathrm{H}-1 \\
\text { to } \\
4 \mathrm{H}-2 \\
\end{array}$ & $6 \mathrm{H}+4$ & $\begin{array}{c}4 \mathrm{H}-1 \\
\text { to } \\
5 \mathrm{H}-1\end{array}$ & $\begin{array}{c}5 H-1 \\
\text { to } \\
6 H+1 \\
\end{array}$ & $\begin{array}{c}3 H-4 \\
t 0 \\
6 H-4 \\
\end{array}$ & $\begin{array}{l}4 H-4 \\
\text { to } \\
9 H-1\end{array}$ & $\begin{array}{c}3 \mathrm{H}-1 \\
\text { to } \\
4 \mathrm{H}-1\end{array}$ & $\begin{array}{l}2 H+1 \\
\text { to } \\
2 H+4\end{array}$ \\
\hline & $\begin{array}{c}\text { Dictyocha } \\
\text { extensa }\end{array}$ & $4 \mathrm{H}-4$ & $\begin{array}{c}7 H-4 \\
\text { to } \\
22 x-1\end{array}$ & $\begin{array}{c}6 H+1 \\
\text { to } \\
7 H-1\end{array}$ & $\begin{array}{c}6 H-4 \\
\text { to } \\
24 X-1 \\
24\end{array}$ & $\begin{array}{c}7 H+1 \\
\text { to } \\
16 \times-1\end{array}$ & $\begin{array}{c}10 H-1 \\
\text { to } \\
12 \mathrm{H}-4 \\
\end{array}$ & $\begin{array}{l}5 \mathrm{SH}-1 \\
\text { to } \\
7 \mathrm{H}-1\end{array}$ & \\
\hline \multirow{4}{*}{$\begin{array}{l}\text { late } \\
\text { Mocene }\end{array}$} & $\begin{array}{c}\text { Distephanus } \\
\text { xenus }\end{array}$ & & $\begin{array}{r}21 x-1 \\
t 0 \\
22 x-1 \\
\end{array}$ & & $20 x-1$ & & & & \\
\hline & $\begin{array}{c}\text { B. diodon nodosa } \\
\text { assemblage }\end{array}$ & & $22 x-4$ & $7 \mathrm{H}-4$ & $20 x-4$ & $16 x-4$ & $13 \mathrm{H}-1$ & & \\
\hline & $\begin{array}{c}\text { Distephanus } \\
\text { speculum tenuis }\end{array}$ & $\begin{array}{l}5 H-2 \\
\text { to } \\
\text { SH-2 }\end{array}$ & $\begin{array}{l}22 x-4 \\
\text { to } \\
24 x-1 \\
\end{array}$ & $\mathrm{BH}-1$ & $\begin{array}{l}25 x-1 \\
\text { to } \\
28 x-1\end{array}$ & $\begin{array}{c}17 x-1 \\
t 0 \\
26 x-1 \\
26 x-1\end{array}$ & $\begin{array}{c}144-1 \\
\text { to } \\
19 x-1 \\
\end{array}$ & $8 \mathrm{H}-1$ & \\
\hline & $\begin{array}{c}\text { Dictyocha } \\
\text { varia }\end{array}$ & $\begin{array}{c}6 \mathrm{6H}-2 \\
\text { to } \\
11 \mathrm{H}-2 \\
\end{array}$ & & $\begin{array}{c}9 \mathrm{H}-1 \\
\text { to } \\
10 \mathrm{H}-4 \\
\end{array}$ & $\begin{array}{l}29 x-1 \\
\text { to } \\
37 x-1 \\
\end{array}$ & $\begin{array}{c}27 x-1 \\
t 0 \\
42 x-1 \\
42 x\end{array}$ & $\begin{array}{r}20 x-1 \\
t 0 \\
26 x-1 \\
\end{array}$ & $\begin{array}{c}9 \mathrm{H}-1 \\
\text { to } \\
12 \mathrm{H}-1 \\
\end{array}$ & \\
\hline $\begin{array}{l}\text { middle } \\
\text { Mocene }\end{array}$ & $\begin{array}{l}\text { Dictyocha } \\
\text { subclinata }\end{array}$ & $7 \mathrm{H}-4$ & & & & $33 x-1$ & $25 x-1$ & & \\
\hline \multirow{3}{*}{$\begin{array}{l}\text { early } \\
\text { Mocene }\end{array}$} & $\begin{array}{l}\text { Corbisema } \\
\text { triacantha }\end{array}$ & $\begin{array}{c}11+-4 \\
\text { to } \\
31 x-5\end{array}$ & & & & & & & \\
\hline & $\begin{array}{l}\text { Distephanus } \\
\text { stauracantha }\end{array}$ & $\begin{array}{c}12 \mathrm{H}-4 \\
\text { to } \\
17 \mathrm{H}-5\end{array}$ & & & & & & & \\
\hline & $\begin{array}{l}\text { D. varia } \\
\text { (deflandroid) }\end{array}$ & $29 x-2$ & & & & & & & \\
\hline
\end{tabular}

Figure 3. Silicoflagellate zones found in Leg 138 sediments.

$138-844 \mathrm{~B}-11 \mathrm{H}-4,120-121 \mathrm{~cm}$, which is the last consistent occurrence of C. triacantha, although this taxon made up only 9 of 300 specimens that were counted. The taxon was scattered in samples that were located higher in the interval, but these are presumed to have been reworked. The Distephanus stauracanthus Horizon (see Locker and Martini, 1986b) occurs from Samples 138-844B-12H-4, 120-121 $\mathrm{cm}$, to $-17 \mathrm{H}-4,120-121 \mathrm{~cm}$. The occurrence of D. stauracanthus, however, is not consistent through this interval and it appears to be most abundant at the very top and very bottom of the horizon.

Sample 138-844B-15H-2, 120-121 cm, includes abundant deflandroid variants of Dictyocha varia and D. extensa. A similar acme has been described by Bukry $(1984,1985)$ and appears to be of the same age. The acme is recognized here as the Dictyocha varia (deflandroid) Horizon.

\section{Site 847}

Site 847 is the equatorial site for the eastern transect and is located $21 \mathrm{~km}$ from the equator and about $389 \mathrm{~km}$ west of the Galapagos Islands. The site was selected to obtain a detailed record of the equatorial divergence near the American continents, where the Equatorial Undercurrent (Fig. 1) interacts with surface waters. Backtracking the location of this site shows that it has remained within the equatorial divergence throughout its history.

The sedimentary section at Site 847 spans the lower Miocene to Pleistocene and comprises a single lithologic unit of diatom nannofossil ooze. There are two intervals (1.5-1.9 and 4.3-4.6 Ma) where the section is dominated by diatom ooze. Sedimentation rates averaged about $30 \mathrm{~m} / \mathrm{m} . y$., peaking at a rate of $50 \mathrm{~m} / \mathrm{m}$.y. during the early Pliocene. Hole $847 \mathrm{~B}$, which was examined for silicoflagellates, was APC-cored to $139 \mathrm{mbsf}$, then XCB-cored until reaching a chert layer at 251 mbsf.

Abundances of Dictyocha aculeata are much higher in the Pleistocene section of Hole 847B than are those in Hole 844B (Table 4). This taxon thrives in near equatorial water and its relative abundance decreases away from the equator. Bachmannocena quadrangula also is thicker and more abundant in Hole 847B than in Hole 844B. The
Dictyocha messanensis Zone is represented by two samples in Hole $847 \mathrm{~B}$, and in a single sample in Hole 844B. This zone is much thicker in holes studied from the western transect.

The Dictyocha extensa Zone extends for $130 \mathrm{~m}$ in the lower Pliocene and upper Miocene sediments. This zone includes the Distephanus xenus Horizon near the bottom of the zone. The Distephanis speculum tenuis Zone is represented by three samples near the bottom of the cored Hole 847B interval. This zone is not as thick in Hole $847 \mathrm{~B}$ as it is at equatorial sites on the western transect. Sample $138-847 \mathrm{~B}-22 \mathrm{X}-4,120-121 \mathrm{~cm}$, which is the topmost sample of the D. speculum tenuis Zone, is very unusual in comparison to the other Leg 138 sites because it shows a co-occurrence of $D$. speculum tenuis and the Bachmannocena diodon nodosa plexus. These taxa do not co-occur at Holes 848B, 850B, and 851B, and in Hole 949B where the two intervals are separated by several samples. We do not have an explanation for this finding.

\section{Site 848}

Site 848 is the southernmost site of the western transect (Fig. 1). Four holes were drilled at this site to assure continuous recovery and to provide sufficient volume of material for high-resolution analyses. Samples from Hole 848B, which was APC-cored to basement at 93.3 mbsf, were examined for silicoflagellates.

Hole $848 \mathrm{~B}$ provided a continuous sedimentary section spanning the time interval from the Quaternary to the middle Miocene. The sedimentary sequence consisted of a single lithologic unit dominated by foraminifer nannofossil ooze. Siliceous microfossils were present in minor amounts throughout the section with rhythmically interbedded layers of diatom nannofossil ooze. Preservation of siliceous fossils generally is very good, although the lower $10 \mathrm{~m}$ of the section is barren. Silicoflagellates are relatively abundant through most of the section, but ebridians are absent (Table 5).

Silicoflagellates generally are not found to be abundant in the late Pleistocene Dictyocha aculeata Zone but are more abundant in the rest of the Pleistocene and Pliocene. The Bachmannocena quadran- 
gula Zone occurs in Samples 138-848B-3H-1, 120-121 cm, and $-848 \mathrm{~B}-3 \mathrm{H}-4,120-121 \mathrm{~cm}$, but the nominate taxon is less abundant in the latter sample. The lowest common Dictyocha messanensis occurs in Sample 138-848B-5H-1, 120-121 cm, while the highest abundant Dictyocha extensa was found in Sample 138-848B-6H-1, 120-121 $\mathrm{cm}$; Sample 138-848B-5H-4, 120-121 cm, located between these two events has been left unzoned.

The Bachmannocena diodon nodosa plexus was found in Sample $138-848 \mathrm{~B}-7 \mathrm{H}-4,120-121 \mathrm{~cm}$, where the plexus morphologies represent a majority of the silicoflagellates, but was absent in samples from a few meters above and below it. The Neonaviculopsis morphologies were not found. Whether the thinness of this horizon is due to the slow accumulation rate (about $5 \mathrm{~m} / \mathrm{m}$.y.) or because of zonal thinning away from the equator is uncertain. Distephanus speculum tenuis, which forms a distinct and thick zone at sites very near the equator is rare in Hole 848B, with only three specimens found in Sample 138-848B$8 \mathrm{H}-1,119-120 \mathrm{~cm}$.

\section{Site 849}

Site 849 is located less than $20 \mathrm{~km}$ from the equator, within the equatorial divergence zone (Fig. 1). Four holes were drilled. Hole $849 \mathrm{~B}$, was APC-cored to $120.7 \mathrm{mbsf}$, then XCB-cored to basement at $350.5 \mathrm{~m}$. This hole provided a sedimentary section that spanned the time interval from the Quaternary to the middle Miocene (Fig. 3). The sedimentary sequence consisted of a single lithologic unit composed primarily of a diatom nannofossil ooze with minor intervals of diatom ooze.

Sedimentation rates in the upper Pliocene and Pleistocene sediments were relatively high and ranged from 25 to $35 \mathrm{~m} / \mathrm{m}$.y. This is reflected in a Dictyocha aculeata Zone that is relatively thick when compared to that at the nearby Hole 850B. Dictyocha aculeata is also much more abundant in Hole $849 \mathrm{~B}$ than at other sites, suggesting that this species thrives particularly well near $\left(<1^{\circ}\right.$ latitude) the equator. An unusual abundance of Dictyocha calida ampliata was found in Sample 138-849B-1H-4, 120-121 cm; this taxon was rare in all other Leg 138 holes studied for silicoflagellates (Table 6).

The Bachmannocena quadrangula Zone occurs in Samples 138$849 \mathrm{~B}-4 \mathrm{H}-1,130-131 \mathrm{~cm}$, and $-4 \mathrm{H}-4,120-121 \mathrm{~cm}$. Bachmannocena quadragula is abundant in these samples, but is not predominant as Holes $848 \mathrm{~B}, 850 \mathrm{~B}$, and $851 \mathrm{~B}$, suggesting that the abundance of this taxon may decrease close to the equator. This zone also included abundant Dictyocha aculeata, which is rare in the B. quadrangula Zone of Holes $848 \mathrm{~B}, 850 \mathrm{~B}, 85 \mathrm{IB}$; again this suggests that this species does especially well in near-equatorial waters and further indicates that $D$. aculeata may have evolved in near-equatorial waters and spread from there to higher latitudes.

The Dictyocha messanensis Zone extends downward to Sample $138-849 \mathrm{~B}-9 \mathrm{H}-1,120-121 \mathrm{~cm}$. One interesting sample in this interval is Sample 138-849B-6H-4, 120-121 cm, in which D. messanensis was not found at all, while Distephanus speculum speculum has an unusual dominance. This may suggest a cooling at the time that the sediments of this sample were deposited, since a dominance of $D$. speculum typically is associated with cooler climatic conditions.

Samples $138-849 \mathrm{~B}-25 \mathrm{X}-1,120-121 \mathrm{~cm}$, to $-28 \mathrm{X}-1,120-121 \mathrm{~cm}$, contains an unusual six-sided Distephanus that often lacks an apical ring as a result of the weakness of the thin structure; this constitutes the Distephanus speculum tenuis Zone. The nominate taxon of this zone appears to be common only in sites that are within about $5^{\circ}$ of the equator. $D$. speculum tenuis is especially abundant in Sample 138-849B-27X-1, 120-121 cm.

An unusual assemblage of Bachmannocena diodon nodosa variants occurs in Sample 138-849B-20X-4, 120-121 cm. This marks the Bachmannocena diodon nodosa Assemblage Horizon of the Dictyocha extensa Zone. This assemblage includes a wide variety of bach- mannocenid morphologies in which an apical bridge extends across the width of the skeleton. The similar Neonaviculopsis neonautica occurs in Sample 138-849B-19X-4, 120-121 cm, which is just above the $B$. diodon nodosa Horizon.

\section{Site 850}

The location for Site 850 was chosen to increase the spacial resolution between Sites 849 and -851 to detect narrow gradients $\left( \pm 1^{\circ}\right.$ of latitude) of change in surface productivity within the equatorial divergence zone. Only two holes were drilled. Hole $850 \mathrm{~B}$, which was used for silicoflagellate study, was APC-cored to $98 \mathrm{mbsf}$, then XCB-cored to basement at 399.9 mbsf.

The sedimentary section at Site 850 spans the upper middle Miocene to Pleistocene and comprises a single lithologic unit of nannofossil ooze. Silicoflagellates are generally abundant, and preservation is good. As at Site 848, silicoflagellates are relatively sparse in the late Pleistocene. Silicoflagellates are abundant, with Bachmannocena quadrangula predominating, in Samples 138-850B-2H-4, 120-121 $\mathrm{cm}$, and $-850 \mathrm{~B}-3 \mathrm{H}-1,120-121 \mathrm{~cm}$; the nominate taxon is less predominant in Sample 138-850B-3H-4, 120-121 cm (Table 7).

An interval in the late early Pliocene and early late Pliocene, extending from Sample 138-850B-6H-4, $120-121 \mathrm{~cm}$, to $-850 \mathrm{~B}-9 \mathrm{H}-$ I, 120-121 cm, was difficult to interpret because of a wide range of silicoflagellates that were intermediate between $D$. messanensis, $D$. extensa, and D. perlaevis; this interesting group was simply categorized as Dictyocha species. A similar range of Dictyocha skeletal morphologies was found at other Leg 138 sites near the equator and Bukry (1982a, 1982b, 1983) found a similarly ambiguous grouping of silicoflagellates at equatorial sites that he termed " $D$. fibula s. ampl." This interval may create difficulties in zoning because those who study silicoflagellates will probably interpret this group in different ways.

As at Hole $848 \mathrm{~B}$, unusual skeletal morphologies associated with Bachmannocena diodon nodosa were found in a narrow interval. These morphologies were abundant in Sample 138-850B-16X-4, $120-121 \mathrm{~cm}$, but did not occur in samples from a few meters above and below. However, unlike the occurrence in Hole 848B, Neonaviculopsis morphologies were found associated with $B$. d. nodosa, as well as in the samples immediately above and below the nodosabearing slide.

An interesting morphology of Distephanus speculum speculum that lacks an apical apparatus occurs over a lengthy interval extending from Sample $138-850 \mathrm{~B}-17 \mathrm{X}-1,120-121 \mathrm{~cm}$, to $850 \mathrm{~B}-26 \mathrm{H}-1,120$ $121 \mathrm{~cm}$. This interval, the Distephanus speculum tenuis Zone, covers almost $100 \mathrm{~m}$ of strata. At Site 850 , this zone occurs just below the Bachmannocena diodon nodosa Horizon. Lengthy sediment intervals that include this taxon occur only at sites very near the equator.

\section{Site 851}

Site 851 is presently located at the northern edge of the westward-flowing South Equatorial Current (SEC) (Fig. 1). The sedimentary sequence spans the interval from the uppermost middle Miocene to the Pleistocene and comprises a single lithologic unit composed of foraminifer nannofossil oozes and diatom nannofossil ooze. Hole $851 \mathrm{~B}$, which was examined for silicoflagellates, was APC-cored to $121.5 \mathrm{mbsf}$ and then XCB-cored to basement at $318 \mathrm{mbsf}$. The age of basement is about 11 to $12 \mathrm{~m} . \mathrm{y}$., showing a high sediment accumulation rate caused by elevated productivity.

The silicoflagellate occurrences in Hole 851B are similar to those of Hole 850B (Table 8). Silicoflagellate abundances are low in the Pleistocene Dictyocha aculeata Zone, and Bachmannocena quadrangula are abundant in a narrow interval. Dictyocha sp., the varied group of foursided silicoflagellates mentioned earlier that do not fit easily into the established taxonomy, occurs throughout the Dictyocha 
Table 4. Abundance of silicoflagellates and ebridians in selected samples from Hole 847B.

\begin{tabular}{|c|c|c|c|c|c|c|c|c|c|c|c|c|c|c|c|c|c|c|}
\hline Age & Zone & $\begin{array}{l}\text { Core, section, } \\
\text { interval }(\mathrm{cm})\end{array}$ & $\begin{array}{l}\text { Depth } \\
\text { (mbsf) }\end{array}$ & 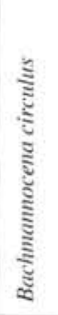 & 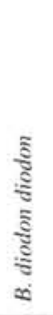 & 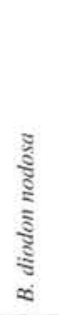 & 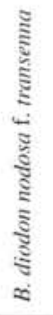 & 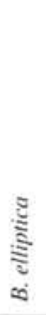 & 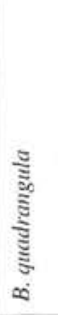 & 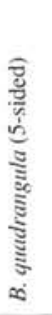 & 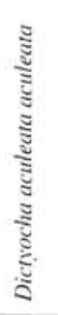 & 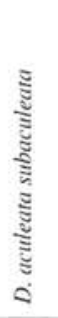 & 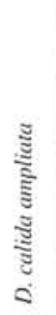 & 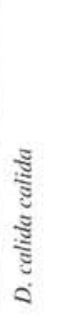 & 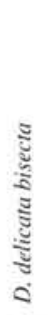 & 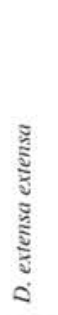 & 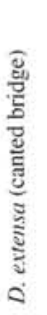 & 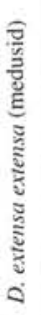 \\
\hline \multirow{2}{*}{ Pleistocene } & D. aculeata & $\begin{array}{l}1 \mathrm{H}-1,120-12 \mathrm{1} \\
2 \mathrm{H}-4,120-12 \mathrm{1} \\
3 \mathrm{H}-4,120-12 \mathrm{1}\end{array}$ & $\begin{array}{l}1.2 \\
12.2 \\
21.7\end{array}$ & & & & & & & & $\begin{array}{r}32 \\
6 \\
15\end{array}$ & $\begin{array}{l}69 \\
13 \\
47\end{array}$ & & $\begin{array}{l}12 \\
13 \\
4\end{array}$ & & & & \\
\hline & B. quadrangula & $\begin{array}{l}4 \mathrm{H}-4,120-121 \\
5 \mathrm{H}-4,120-12 \mathrm{I}\end{array}$ & $\begin{array}{l}31.2 \\
40.7\end{array}$ & & & & & & $\begin{array}{r}118 \\
90\end{array}$ & 7 & 1 & & 1 & & & & & \\
\hline \multirow{2}{*}{$\begin{array}{c}\text { late } \\
\text { Pliocene }\end{array}$} & D. messanensis & $\begin{array}{l}6 \mathrm{H}-4,120-121 \\
8 \mathrm{H}-\mathrm{I}, 120-12 \mathrm{I}\end{array}$ & $\begin{array}{l}50.2 \\
64.7\end{array}$ & & & & & & 1 & & & & $\begin{array}{l}8 \\
5\end{array}$ & & 1 & $\begin{array}{r}117 \\
99\end{array}$ & & \\
\hline & \multirow{3}{*}{ D. extensa } & $\begin{array}{l}10 \mathrm{H}-2,120-121 \\
11 \mathrm{H}-1,113-114 \\
12 \mathrm{H}-1,120-121\end{array}$ & $\begin{array}{r}85.2 \\
93.1 \\
102.7\end{array}$ & $\begin{array}{r}7 \\
30 \\
5\end{array}$ & & & & & & & & & 2 & 1 & 3 & $\begin{array}{l}88 \\
29 \\
98\end{array}$ & $\begin{array}{r}19 \\
5\end{array}$ & 1 \\
\hline \multirow[t]{2}{*}{$\begin{array}{c}\text { early } \\
\text { Pliocene }\end{array}$} & & $\begin{array}{l}14 X-1,124-125 \\
15 X-1,120-121 \\
16 X-1,123-124 \\
17 X-1,123-124 \\
18 X-1,123-124 \\
10 X\end{array}$ & $\begin{array}{l}121.7 \\
131.2 \\
140.7 \\
147.0 \\
156.7\end{array}$ & $\begin{array}{r}9 \\
17 \\
43 \\
9\end{array}$ & & & & & $\begin{array}{r}1 \\
18\end{array}$ & & & & 6 & $\begin{array}{r}13 \\
8\end{array}$ & 15 & $\begin{array}{r}194 \\
80 \\
125 \\
43 \\
110 \\
45\end{array}$ & $\begin{array}{r}10 \\
41 \\
5 \\
40 \\
26\end{array}$ & \\
\hline & & $\begin{array}{l}20 \mathrm{X}-1,122-123 \\
21 \mathrm{X}-1.122-123 \\
22 \mathrm{X}-1.123-124\end{array}$ & $\begin{array}{l}175.1 \\
184.7 \\
194.4\end{array}$ & & & 1 & & & $\begin{array}{r}29 \\
10 \\
4\end{array}$ & & & & & 3 & 3 & $\begin{array}{l}39 \\
41 \\
83\end{array}$ & $\begin{array}{r}31 \\
5\end{array}$ & \\
\hline \multirow[t]{2}{*}{$\begin{array}{c}\text { late } \\
\text { Miocene }\end{array}$} & Ds. specutum temais & $\begin{array}{l:l}22 X-4, & 123-124 \\
2.3 X-4, & 122-123 \\
24 X-1, & 122-123\end{array}$ & $\begin{array}{l}204.0 \\
213.7 \\
222.4\end{array}$ & & & 48 & 2 & & & & & & & 2 & & $\begin{array}{r}1 \\
58 \\
173\end{array}$ & & \\
\hline & D. varia & $25 X-1,122-123$ & 232.1 & & & & & & & & & & & & & 213 & & \\
\hline
\end{tabular}

Notes: Species (in alphabetical order) are recorded as total number of specimens found in the slides examined.

Table 5. Abundance of silicoflagellates and ebridians in selected samples from Hole 848B.

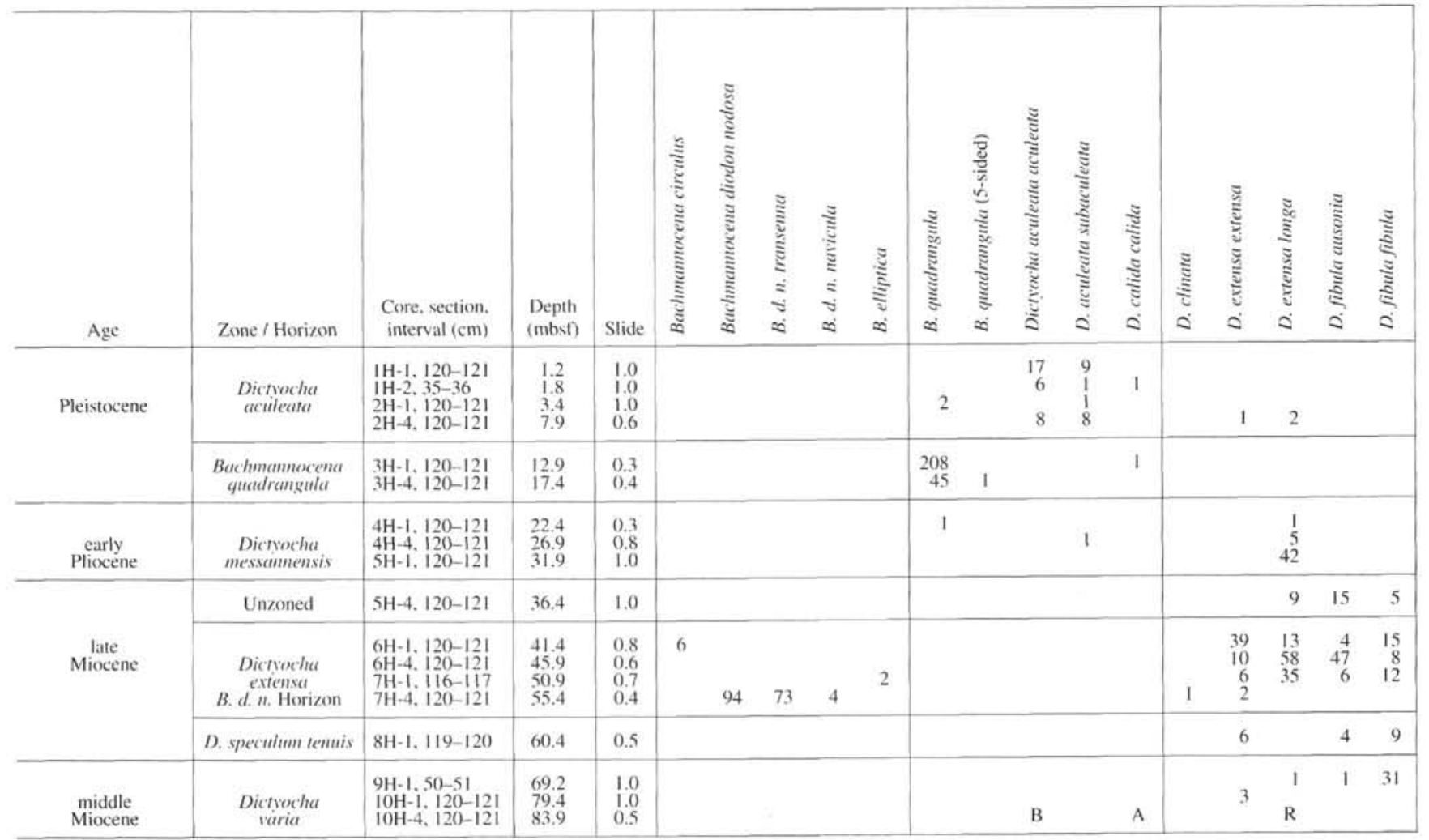

Note: Species (in alphabetical order) are recorded as total number of specimens found in the slides examined. 
Table 4 (continued).

\begin{tabular}{|c|c|c|c|c|c|c|c|c|c|c|c|c|c|c|c|c|c|c|c|c|c|c|c|c|}
\hline \multirow[t]{4}{*}{ 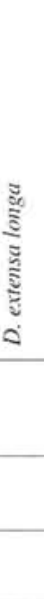 } & \multirow[t]{4}{*}{ 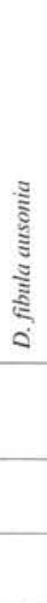 } & \multirow[t]{4}{*}{ 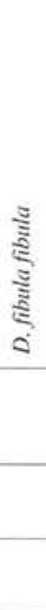 } & \multicolumn{2}{|l|}{ 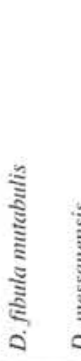 } & & \multirow[t]{2}{*}{ 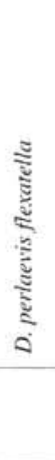 } & 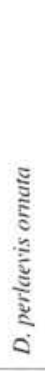 & $\frac{n}{\vdots}$ & 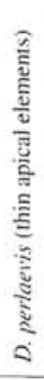 & $\frac{\tilde{Z}}{\tilde{\Xi}}$ & \multicolumn{2}{|c|}{ 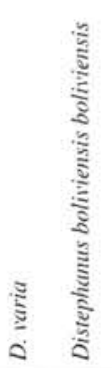 } & $\begin{array}{l}\vdots \\
\vdots \\
\vdots \\
\vdots \\
0\end{array}$ & \multirow{2}{*}{ 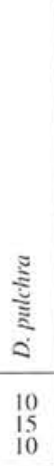 } & \multirow[t]{2}{*}{ 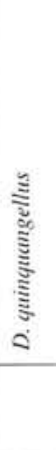 } & 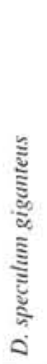 & 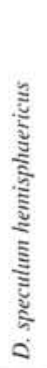 & 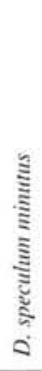 & 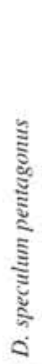 & \multirow[t]{2}{*}{ 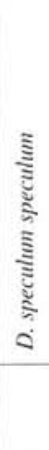 } & 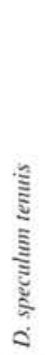 & $\frac{\cong}{3}$ & 龸 & 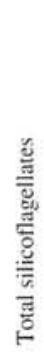 \\
\hline & & & & & & & & $\begin{array}{r}6 \\
1.32 \\
3\end{array}$ & $\frac{1}{2}$ & 2 & & & & & & & 1 & & 5 & & & & $\begin{array}{l}1 \\
1\end{array}$ & $\begin{array}{l}300 \\
300 \\
300\end{array}$ \\
\hline & & & & $\begin{array}{l}122 \\
143\end{array}$ & $\begin{array}{l}7 \\
4\end{array}$ & & & $\begin{array}{l}35 \\
44\end{array}$ & 3 & 2 & & & & $\begin{array}{r}6 \\
14\end{array}$ & & & & & & 3 & & & & $\begin{array}{l}300 \\
300\end{array}$ \\
\hline & & & & 21 & $\begin{array}{l}52 \\
40\end{array}$ & & 2 & $\begin{array}{l}35 \\
69\end{array}$ & $\begin{array}{r}14 \\
4\end{array}$ & & & 1 & & 4 & $\begin{array}{r}6 \\
28\end{array}$ & & & & $\begin{array}{r}4 \\
2.3\end{array}$ & $\begin{array}{l}34 \\
32\end{array}$ & & & 1 & $\begin{array}{l}300 \\
300\end{array}$ \\
\hline $\begin{array}{r}4 \\
22 \\
2 \\
8 \\
11 \\
11\end{array}$ & $\begin{array}{r}12 \\
3 \\
18 \\
4\end{array}$ & $\begin{array}{l}1 \\
8 \\
1 \\
5 \\
9 \\
5\end{array}$ & $\begin{array}{r}5 \\
1 \\
1 \\
6 \\
15 \\
4 \\
3 \\
4\end{array}$ & & & 25 & & $\begin{array}{r}112 \\
175 \\
120 \\
31 \\
12 \\
98 \\
85 \\
7 \\
24 \\
5 \\
3 \\
3 \\
1\end{array}$ & $\begin{array}{r}11 \\
1 \\
19 \\
8\end{array}$ & & $\begin{array}{r}5 \\
3 \\
1 \\
8 \\
27\end{array}$ & $\begin{array}{r}10 \\
1 \\
5 \\
1 \\
1 \\
4 \\
4 \\
3 \\
11 \\
2\end{array}$ & $\begin{array}{l}1 \\
1 \\
2 \\
7 \\
6 \\
1 \\
4 \\
3\end{array}$ & & $\begin{array}{l}2 \\
1 \\
2\end{array}$ & $\begin{array}{r}2 \\
22 \\
9 \\
11 \\
119 \\
45\end{array}$ & $\begin{array}{l}4 \\
1\end{array}$ & $\begin{array}{l}4 \\
4 \\
8 \\
1\end{array}$ & 4 & $\begin{array}{r}38 \\
22 \\
25 \\
18 \\
22 \\
65 \\
32 \\
132 \\
41 \\
56 \\
151 \\
58 \\
46\end{array}$ & & 14 & $\begin{array}{l}2 \\
1 \\
1\end{array}$ & $\begin{array}{l}300 \\
300 \\
300 \\
300 \\
193 \\
300 \\
300 \\
300 \\
300 \\
300 \\
300 \\
300 \\
300\end{array}$ \\
\hline $\begin{array}{r}13 \\
7\end{array}$ & $\begin{array}{r}7 \\
18\end{array}$ & 5 & 120 & & & & & $\begin{array}{l}31 \\
15\end{array}$ & & & 52 & $\begin{array}{l}7 \\
3\end{array}$ & $\begin{array}{l}3 \\
3\end{array}$ & & 1 & $\begin{array}{l}30 \\
10 \\
25\end{array}$ & & 4 & 1 & $\begin{array}{l}99 \\
41 \\
43\end{array}$ & $\begin{array}{l}14 \\
41\end{array}$ & 19 & & $\begin{array}{l}300 \\
300 \\
300\end{array}$ \\
\hline & & 3 & & & & & & & & & & 3 & 28 & & & 2 & & 3 & I & 30 & 10 & & & 300 \\
\hline
\end{tabular}

Table 5 (continued).

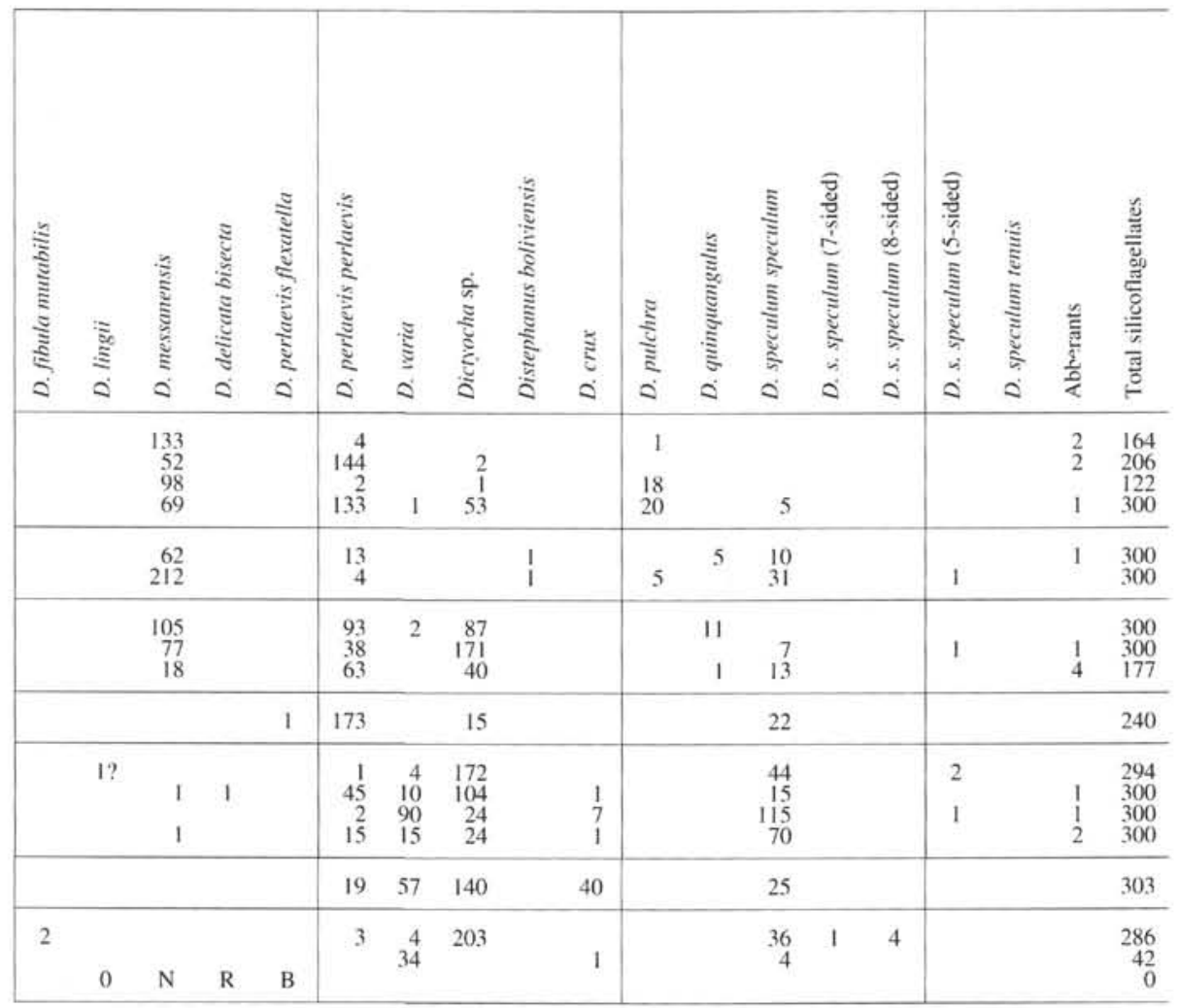


Table 6. Abundance of silicoflagellates and ebridians in selected samples from Hole 848B.

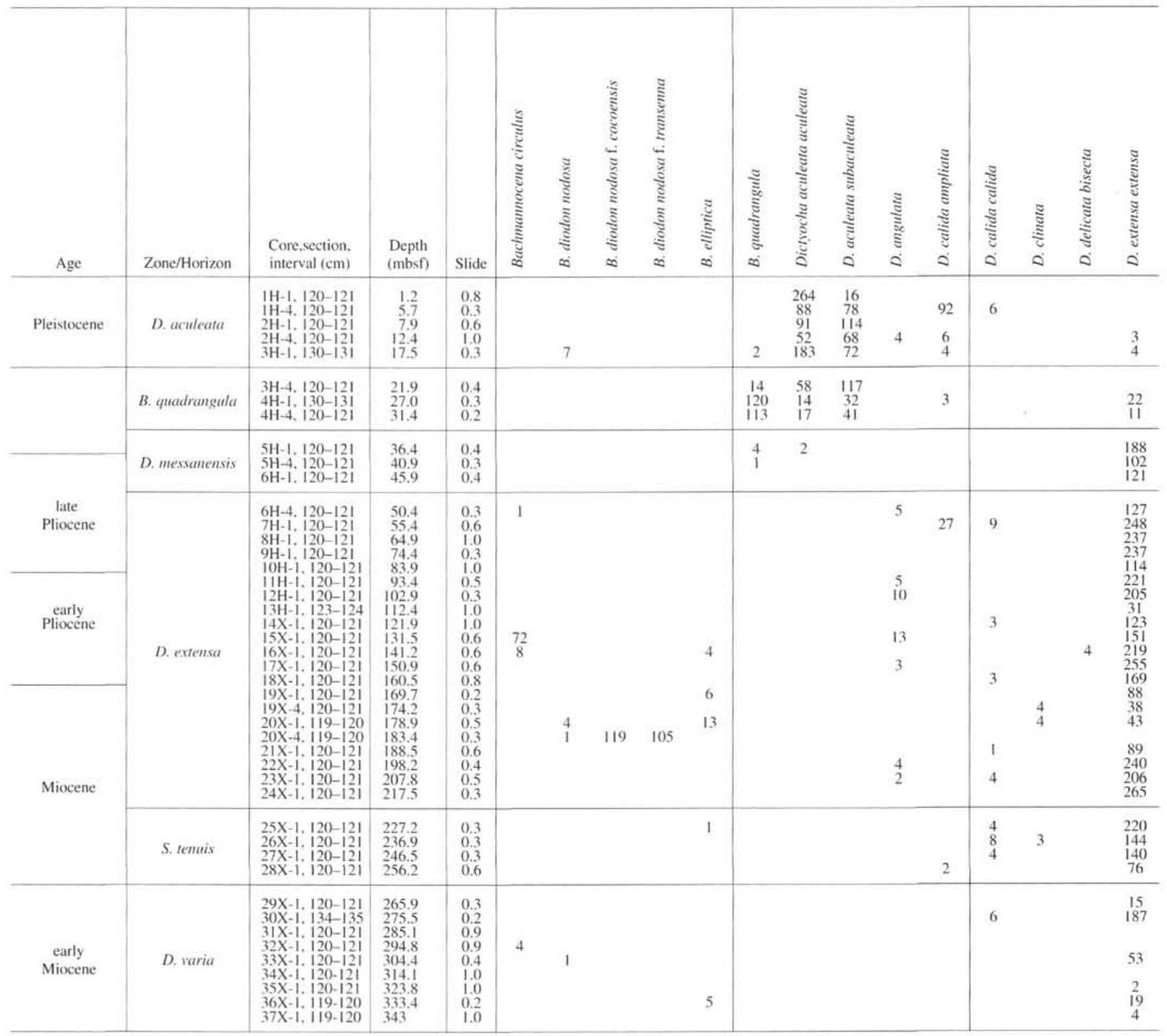

Note: Species (in alphabetical order) are recorded as total number of specimens found in the slides examined.

messanensis and $D$. extensa zones and reaches a peak in Sample 138-85।B$10 \mathrm{H}-1,120-121 \mathrm{~cm}$.

The Bachmannocena diodon nodosa Horizon was found in Sample $138-85$ IB- $13 \mathrm{H}-1,120-121 \mathrm{~cm}$; this is in a narrow interval, as neither this assemblage nor the Neonaviculopsis morphologies were found in samples from above and below this horizon. Unlike at other Leg 138 holes, an interval exists between the last occurrence of Distephanus speculum tenuis and the Bachmannocena diodon nodosa Horizon. This interval is represented by Sample 138-851B-14H-1, 120-121 cm, and contains an unusually large abundance of Dictyocha perlaevis perlaevis. The Distephanus speculum tenuis Zone extends for about 50 meters, which is half the thickness of the zone in Hole 850B; the nominate taxon is also less abundant in Hole 851B. The decreasing thickness of the Distephanus speculum tenuis interval and the declining predominance of these skeletal morphologies suggest that the environmental conditions that produced this unusual occurrence are located near the equator and rapidly change away from that latitude.

\section{Site 852}

Site 852 is located at the seasonal boundary between the westwardflowing South Equatorial Current (SEC) and the eastward-flowing North Equatorial Current (NEC) (Fig. 1). The sedimentary sequence consists of a single lithologic unit that extends from the uppermost middle Miocene to Pleistocene. Pliocene and Pleistocene sediments consist of a mixture of formaminifer nannofossil and nannofossil foraminifer oozes, with a radiolarian nannofossil ooze in the lower Pliocene and Miocene. Sedimentation rates are much less than at Site 849.

Hole $852 \mathrm{~B}$ was APC-cored to 113.4 mbsf, which was near the basement. Silicoflagellates usually were much less abundant here than in other holes nearer the equator (Table 9). The Bachmannocena quadrangula Zone was not found, suggesting that it may be too thin at this location to be readily detected using a 5-m sample interval. The Distephanus speculum tenuis Zone was recognized 
Table 6 (continued).

\begin{tabular}{|c|c|c|c|c|c|c|c|c|c|c|c|c|c|c|c|c|c|c|c|c|}
\hline 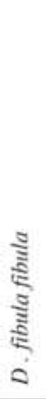 & 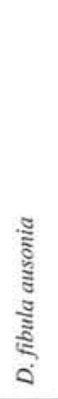 & 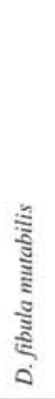 & 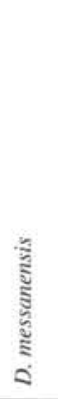 & 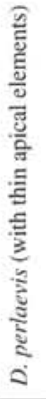 & 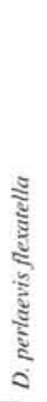 & 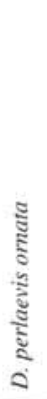 & 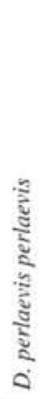 & 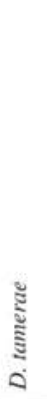 & 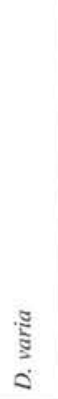 & 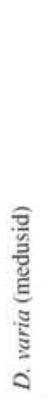 & 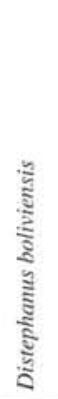 & $\begin{array}{l}\text { है } \\
\text { है } \\
\vdots\end{array}$ & $\frac{\Xi}{\stackrel{\Xi}{\Xi}}$ & 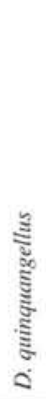 & 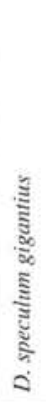 & 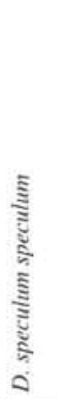 & 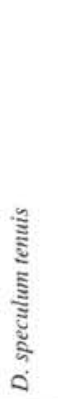 & 产 & 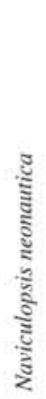 & 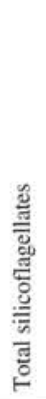 \\
\hline & & & $\begin{array}{l}14 \\
61 \\
84 \\
18\end{array}$ & $\begin{array}{c}21 \\
2\end{array}$ & & & $\begin{array}{l}10 \\
11 \\
8\end{array}$ & & & & & & $\begin{array}{c}8 \\
1 \\
23 \\
14 \\
10\end{array}$ & 1 & & 1 & & & & $\begin{array}{l}300 \\
300 \\
300 \\
241 \\
300 \\
\end{array}$ \\
\hline & & & $\begin{array}{c}8 \\
63 \\
117\end{array}$ & & & & $\begin{array}{l}85 \\
2\end{array}$ & & & & & & $\begin{array}{c}12 \\
1 \\
1\end{array}$ & $\begin{array}{l}1 \\
2\end{array}$ & & $\begin{array}{r}5 \\
41\end{array}$ & & & & $\begin{array}{l}300 \\
300 \\
300\end{array}$ \\
\hline 1 & & 1 & $\begin{array}{l}90 \\
164 \\
146\end{array}$ & $\begin{array}{c}5 \\
10\end{array}$ & & 1 & & & & & & 2 & $\begin{array}{l}3 \\
2 \\
2\end{array}$ & $\begin{array}{c}1 \\
5 \\
21\end{array}$ & & $\begin{array}{r}6 \\
22\end{array}$ & & & & $\begin{array}{l}300 \\
300 \\
300\end{array}$ \\
\hline $\begin{array}{c}1 \\
\\
12 \\
1 \\
9 \\
1 \\
1 \\
5 \\
12 \\
8 \\
7 \\
4 \\
2 \\
2 ? \\
1 \\
1\end{array}$ & $\begin{array}{c}2 \\
2 ? \\
1\end{array}$ & $\begin{array}{c}3 \\
5 \\
6 \\
2 \\
23 \\
1 \\
1 \\
3 \\
2\end{array}$ & $\begin{array}{r}6 \\
33 \\
32\end{array}$ & 1 & 15 & 5 & & $\begin{array}{l}5 \\
9 \\
5\end{array}$ & $\begin{array}{c}1 \\
14 \\
6 \\
5 \\
5 \\
40 \\
9 \\
62 \\
21 \\
23 \\
39 \\
4\end{array}$ & & $\begin{array}{c}13 \\
\\
2 \\
19 \\
100 \\
82 \\
59 \\
111 \\
1\end{array}$ & $\begin{array}{c}5 \\
6 \\
1 \\
2 \\
6 \\
4 \\
2 \\
2 \\
4 \\
\\
7 \\
25 \\
20\end{array}$ & & $\begin{array}{l}1 \\
1 \\
2 \\
1 \\
1 \\
1 \\
2 \\
2 \\
12\end{array}$ & $\begin{array}{l}14 \\
46 \\
\\
4\end{array}$ & $\begin{array}{c}158 \\
8 \\
18 \\
21 \\
140 \\
54 \\
65 \\
19 \\
42 \\
53 \\
48 \\
24 \\
48 \\
84 \\
47 \\
21 \\
49 \\
60 \\
25 \\
25 \\
17\end{array}$ & & 39 & 6 & $\begin{array}{l}300 \\
300 \\
297 \\
300 \\
254 \\
300 \\
300 \\
51 \\
206 \\
300 \\
300 \\
300 \\
300 \\
300 \\
300 \\
300 \\
300 \\
300 \\
300 \\
300 \\
300\end{array}$ \\
\hline 6 & $3 ?$ & $\begin{array}{c}27 \\
23 \\
4\end{array}$ & & & & & & $\begin{array}{c}30 \\
2\end{array}$ & $\begin{array}{c}1 \\
2 ? \\
6 \\
6\end{array}$ & 1 & & $\begin{array}{l}2 \\
1\end{array}$ & & $\begin{array}{c}15 \\
3\end{array}$ & $\begin{array}{l}15 \\
18\end{array}$ & $\begin{array}{l}11 \\
179\end{array}$ & $\begin{array}{l}12 \\
99 \\
1113 \\
24\end{array}$ & & & $\begin{array}{l}300 \\
300 \\
300 \\
300\end{array}$ \\
\hline $\begin{array}{l}8 \\
3\end{array}$ & 72 & $\begin{array}{l}129 \\
22 \\
29\end{array}$ & & & & & & & $\begin{array}{c}27 \\
22 \\
30 \\
79 \\
195 \\
9 \\
207 \\
210 \\
151\end{array}$ & $\begin{array}{l}7 \\
2\end{array}$ & $\begin{array}{l}172 \\
165 \\
\\
29 \\
14\end{array}$ & $\begin{array}{c}1 ? \\
9 \\
8 \\
5 \\
9 \\
11 \\
20\end{array}$ & & $\begin{array}{c}1 \\
10\end{array}$ & $\begin{array}{c}9 \\
11 \\
7 \\
7 \\
6 \\
18 \\
2\end{array}$ & $\begin{array}{l}128 \\
56 \\
27 \\
29\end{array}$ & 1 & & & $\begin{array}{l}300 \\
300 \\
300 \\
300 \\
300 \\
16 \\
254 \\
300 \\
191\end{array}$ \\
\hline
\end{tabular}

in Sample 138-852B-8H-1, 119-120 cm, but only on the basis of five specimens.

\section{Site 854}

Site 854 is the northernmost site on the western transect and was drilled to provide a record of eolian sedimentation in a region influenced by Northern Hemisphere tradewind circulation. The site is presently located in the westward-flowing Northern Equatorial Current (NEC) (Fig. 1). Hole 854B, which was used for silicoflagellate study, was cored with the APC to $45.4 \mathrm{mbsf}$.

Of the seven samples from Hole 854B that were examined for this study, silicoflagellates were relatively abundant only in Sample 138$854 \mathrm{~B}-1 \mathrm{H}-4,120-121 \mathrm{~cm}$ (Table 10). Silicoflagellates were uncommon to rare in Samples 138-854B-1H-1, 120-121 cm, and
$-854 \mathrm{~B}-2 \mathrm{H}-4,120-121 \mathrm{~cm}$, and were barren in the bottommost three samples. Bachmannocena quadrangula was abundant and predominant in Sample 138-854B-1H-4, 120-121 cm, and was much less abundant in Sample 138-854B-2H-1, 120-121 cm.

\section{SYSTEMATIC PALEONTOLOGY}

The synonomies here include only the first description and representative references that show the development of the taxon in the literature. In some cases, the taxonomic usage in this study differs from previous usage by the first author or from others who have studied silicoflagellates; these changes have been made to develop a more standardized silicoflagellate taxonomy or to show infraspecific variation in skeletal morphology that previous researchers have placed in separate genera. An introduction to each of these taxa has been used 
Table 7. Abundance of silicoflagellates and ebridians in selected samples from Hole 850B.

\begin{tabular}{|c|c|c|c|c|c|c|c|c|c|c|c|c|c|c|c|c|c|c|c|c|c|c|c|c|c|}
\hline Age & Zone & $\begin{array}{l}\text { Core, section, } \\
\text { interval }(\mathrm{cm})\end{array}$ & $\begin{array}{l}\text { Depth } \\
\text { (mbsf) }\end{array}$ & Slide & 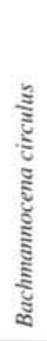 & 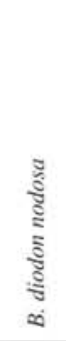 & 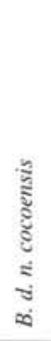 & 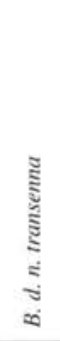 & 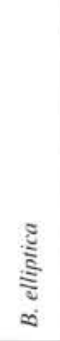 & 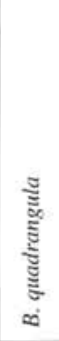 & 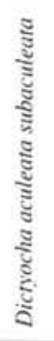 & 气ूँ & 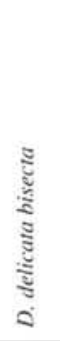 & 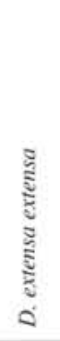 & 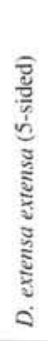 & 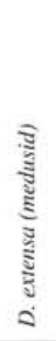 & 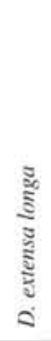 & 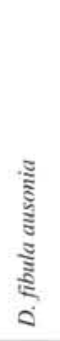 & 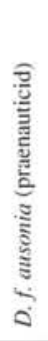 & 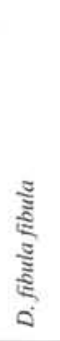 & & 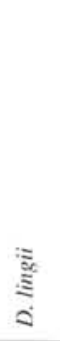 & 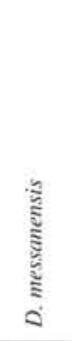 & 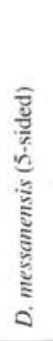 & 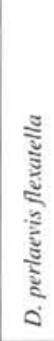 \\
\hline \multirow[b]{2}{*}{ Pleistocene } & D. aculeata & $1 \mathrm{H}-1.120-121$ & 4.2 & 1.0 & & & & & & & & & & & & & & & & & & & 56 & & \\
\hline & $\begin{array}{c}\text { Bachmannocena } \\
\text { quadrangula }\end{array}$ & $\begin{array}{l}2 \mathrm{H}-4,120-121 \\
3 \mathrm{H}-1,120-121\end{array}$ & $\begin{array}{l}18.2 \\
23.2 \\
\end{array}$ & $\begin{array}{l}0.2 \\
0.3 \\
\end{array}$ & & & & & & $\begin{array}{l}183 \\
214 \\
\end{array}$ & 1 & & & & & & 2 & & & & & & 32 & 2 & \\
\hline $\begin{array}{c}\text { late } \\
\text { Pliocene }\end{array}$ & $\begin{array}{c}\text { Dictyocha } \\
\text { messanensis }\end{array}$ & $\begin{array}{l}3 \mathrm{H}-4,120-121 \\
4 \mathrm{H}-1,120-121 \\
5 \mathrm{H}-1,120-121 \\
6 \mathrm{H}-4,120-12 \mathrm{I}\end{array}$ & $\begin{array}{l}27.7 \\
32.7 \\
42.2 \\
56.2\end{array}$ & $\begin{array}{l}0.3 \\
0.3 \\
0.3 \\
0.7\end{array}$ & & & & & & 13 & 1 & & & 58 & & & $\begin{array}{r}1 \\
13 \\
5\end{array}$ & & & 1 & & 1 & $\begin{array}{r}41 \\
179 \\
3 \\
3\end{array}$ & & $\begin{array}{r}1 \\
49 \\
\end{array}$ \\
\hline $\begin{array}{c}\text { early } \\
\text { Pliocene }\end{array}$ & $\begin{array}{l}\text { Dictyocha } \\
\text { extensa }\end{array}$ & $\begin{array}{l}7 \mathrm{H}-4,120-121 \\
9 \mathrm{H}-1,120-121 \\
10 \mathrm{H}-1,120-121 \\
11 \mathrm{X}-1,120-121 \\
12 \mathrm{X}-1,120-121 \\
13 \mathrm{X}-1,120-121 \\
14 \mathrm{X}-1,120-121 \\
15 \mathrm{X}-1,120-121 \\
16 \mathrm{X}-1,120-121 \\
16 \mathrm{X}-4,120-121\end{array}$ & $\begin{array}{r}65.7 \\
80.2 \\
89.7 \\
99.2 \\
108.7 \\
118.3 \\
128.0 \\
137.6 \\
147.3 \\
151.8\end{array}$ & $\begin{array}{l}0.6 \\
0.6 \\
0.8 \\
0.3 \\
0.2 \\
0.5 \\
0.4 \\
0.4 \\
0.6 \\
0.3\end{array}$ & 9 & 167 & 1 & 21 & $\begin{array}{r}26 \\
1 \\
1 \\
2 \\
5\end{array}$ & & & & 2 & $\begin{array}{r}95 \\
60 \\
52 \\
64 \\
29 \\
71 \\
121 \\
46 \\
22 \\
6\end{array}$ & & & $\begin{array}{l}2 \\
4 \\
2 \\
3 \\
2\end{array}$ & $\begin{array}{r}6 \\
1 \\
10 \\
3 \\
4\end{array}$ & & $\begin{array}{l}9 \\
2 \\
1\end{array}$ & & & & & 2 \\
\hline $\begin{array}{c}\text { late } \\
\text { Miocene }\end{array}$ & $\begin{array}{c}\text { Distephanus } \\
\text { speculum } \\
\text { tenuis }\end{array}$ & $\begin{array}{l}17 X-1,120-121 \\
17 X-4,120-121 \\
18 X-1,120-121 \\
19 X-1,120-121 \\
20 X-1,120-121 \\
21 X-1,120-121 \\
22 X-1,120-121 \\
23 X-1,120-121 \\
24 X-1,120-121 \\
25 X-1,120-121 \\
26 X-1,120-121\end{array}$ & $\begin{array}{l}156.9 \\
161.4 \\
166.2 \\
175.4 \\
185.0 \\
194.7 \\
204.3 \\
214.0 \\
223.7 \\
233.3 \\
243.0\end{array}$ & $\begin{array}{l}0.2 \\
0.3 \\
0.3 \\
0.4 \\
0.2 \\
0.5 \\
0.4 \\
0.2 \\
0.2 \\
0.3 \\
0.6\end{array}$ & & & & & 8 & & & & & $\begin{array}{r}81 \\
28 \\
49 \\
233 \\
176 \\
180 \\
219 \\
225 \\
119 \\
94 \\
62\end{array}$ & $\begin{array}{l}1 \\
1 \\
1\end{array}$ & 2 & & $\begin{array}{r}64 \\
16 \\
9 \\
17 \\
4 \\
25\end{array}$ & $\begin{array}{l}1 \\
4\end{array}$ & $\begin{array}{r}5 \\
5 \\
2 \\
2 \\
31 \\
15 \\
8 \\
5 \\
17\end{array}$ & & & & & \\
\hline $\begin{array}{l}\text { middle } \\
\text { Miocene }\end{array}$ & $\begin{array}{l}\text { Dictyocha } \\
\text { varia }\end{array}$ & $\begin{array}{l}27 X-1,120-121 \\
28 X-1,120-121 \\
28 X-4,120-121 \\
29 X-1,120-121 \\
30 X-1,120-121 \\
31 X-1,120-121 \\
32 X-1,120-121 \\
33 X-1,120-121 \\
34 X-3,120-121 \\
35 X-1,120-121 \\
36 X-1,20-121 \\
37 X-4,120-121 \\
38 X-1,120-121 \\
39 X-1,120-121 \\
40 X-1,20-121 \\
41 X-1,120-121 \\
42 X-1,120-121\end{array}$ & $\begin{array}{l}252.2 \\
261.9 \\
266.4 \\
271.5 \\
281.1 \\
290.8 \\
300.4 \\
310.1 \\
322.8 \\
329.4 \\
339.0 \\
353.2 \\
358.3 \\
368.0 \\
377.6 \\
387.3 \\
397.0\end{array}$ & $\begin{array}{l}0.5 \\
0.2 \\
0.1 \\
0.1 \\
0.1 \\
0.3 \\
0.1 \\
0.3 \\
1.0 \\
0.4 \\
0.8 \\
0.5 \\
0.5 \\
1.0 \\
0.3 \\
0.3 \\
0.9\end{array}$ & 2 & & & & 3 & & & & & $\begin{array}{r}68 \\
198 \\
38 \\
23 \\
15 \\
7 \\
26 \\
16 \\
5 \\
4 \\
3 \\
1 \\
3 \\
5 \\
6\end{array}$ & 2 & $\begin{array}{l}2 \\
1 \\
3 \\
1 \\
2\end{array}$ & & $\begin{array}{r}15 \\
20 \\
\\
1 \\
1 \\
11 \\
9\end{array}$ & & $\begin{array}{r}32 \\
7 \\
3 \\
1 \\
2 \\
\\
2 \\
1 \\
\\
1\end{array}$ & & & & & \\
\hline
\end{tabular}


Table 7 (continued).

\begin{tabular}{|c|c|c|c|c|c|c|c|c|c|c|c|c|c|c|c|c|c|c|c|c|c|c|c|c|c|c|}
\hline Age & Zone & 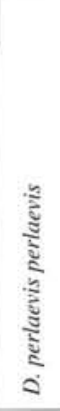 & 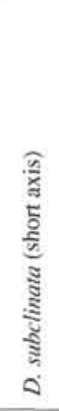 & 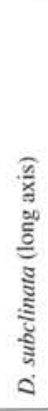 & $\begin{array}{l}\frac{\pi}{5} \\
\vdots \\
0\end{array}$ & 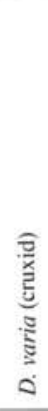 & 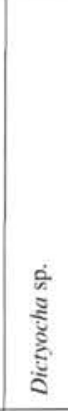 & 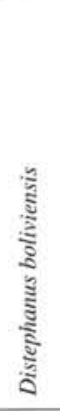 & $\begin{array}{l}\vdots \\
\vdots\end{array}$ & 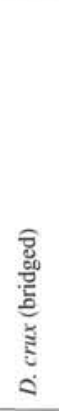 & हूँ & 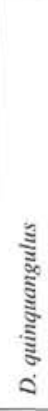 & 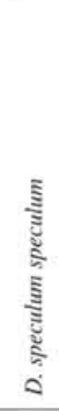 & 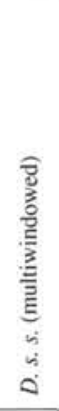 & 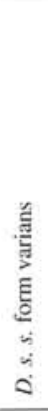 & $\begin{array}{c}\hat{\sigma} \\
\frac{\tilde{g}}{5} \\
0 \\
\vdots \\
\vdots \\
\vdots \\
0\end{array}$ & 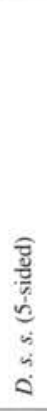 & 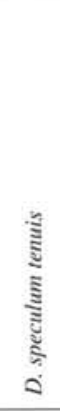 & 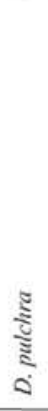 & 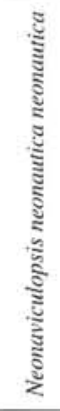 & 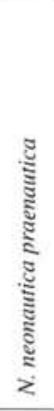 & 起 & 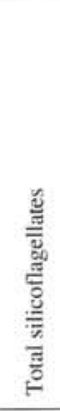 & 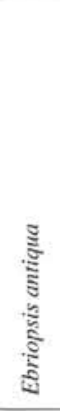 & 离 & 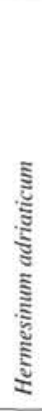 \\
\hline \multirow[b]{2}{*}{ Pleistocene } & D. aculeata & 3 & & & & & & & & & & & & & & & & & & & & & 59 & & & \\
\hline & $\begin{array}{c}\text { Bachmannocena } \\
\text { quadrangula }\end{array}$ & $\begin{array}{r}82 \\
1\end{array}$ & & & & & 2 & & & & & & $\frac{1}{7}$ & & & & & & 2 & & & 2 & $\begin{array}{l}300 \\
300\end{array}$ & & & \\
\hline $\begin{array}{c}\text { late } \\
\text { Pliocene }\end{array}$ & $\begin{array}{l}\text { Dictyocha } \\
\text { messanenis }\end{array}$ & $\begin{array}{r}7 \\
110 \\
7 \\
3\end{array}$ & & & 1 & & $\begin{array}{l}226 \\
245 \\
140\end{array}$ & 1 & i & & & ${ }_{11}^{1}$ & $\begin{array}{r}9 \\
6 \\
2 \\
41\end{array}$ & & & & 15 & & 2 & & & $\begin{array}{l}1 \\
3 \\
2\end{array}$ & $\begin{array}{l}300 \\
300 \\
300 \\
300\end{array}$ & 1 & 1 & \\
\hline $\begin{array}{c}\text { early } \\
\text { Pliocene }\end{array}$ & $\begin{array}{c}\begin{array}{c}\text { Dictyocha } \\
\text { extensa }\end{array} \\
\text { B. d.n. Horizon }\end{array}$ & $\begin{array}{r}11 \\
19 \\
4\end{array}$ & & & $\begin{array}{r}4 \\
\\
1 \\
2 \\
27 \\
54 \\
43 \\
98\end{array}$ & & $\begin{array}{r}147 \\
195 \\
202 \\
172 \\
175 \\
125 \\
26 \\
12 \\
28 \\
28\end{array}$ & $\begin{array}{l}1 \\
3 \\
3\end{array}$ & $\begin{array}{r}2 \\
4 \\
2 \\
9 \\
10 \\
3 \\
3 \\
1 \\
1\end{array}$ & & 6 & $\begin{array}{l}\frac{1}{2} \\
\frac{2}{2}\end{array}$ & $\begin{array}{r}39 \\
18 \\
36 \\
47 \\
53 \\
59 \\
84 \\
182 \\
132 \\
68\end{array}$ & 1 & & $\begin{array}{l}1 \\
1\end{array}$ & & & & $\frac{2}{7}$ & & $\begin{array}{l}1 \\
\frac{1}{2} \\
1\end{array}$ & $\begin{array}{l}300 \\
300 \\
300 \\
300 \\
300 \\
300 \\
300 \\
300 \\
300 \\
300\end{array}$ & 1 & $\begin{array}{l}1 \\
5 \\
3\end{array}$ & 3 \\
\hline $\begin{array}{c}\text { late } \\
\text { Miocene }\end{array}$ & $\begin{array}{c}\text { Distephamus } \\
\text { speculum } \\
\text { tenuis }\end{array}$ & & & & $\begin{array}{r}7 \\
2 \\
1 \\
1 \\
23\end{array}$ & & $\begin{array}{r}40 \\
1 \\
2 \\
\\
3 \\
3 \\
5 \\
2\end{array}$ & $\begin{array}{l}4 \\
1 \\
5\end{array}$ & $\begin{array}{r}6 \\
22 \\
2 \\
1 \\
1 \\
4\end{array}$ & $\frac{1}{2}$ & & $\begin{array}{r}1 \\
2 \\
2 \\
16\end{array}$ & $\begin{array}{r}52 \\
24 \\
184 \\
12 \\
14 \\
17 \\
10 \\
18 \\
25 \\
165 \\
147\end{array}$ & $\begin{array}{l}1 \\
1\end{array}$ & & $\begin{array}{l}1 \\
2\end{array}$ & $\begin{array}{l}1 \\
\\
3 \\
3\end{array}$ & $\begin{array}{r}1 \\
5 \\
45 \\
18 \\
3 \\
18 \\
23 \\
24 \\
124 \\
18 \\
11\end{array}$ & & 156 & 8 & 2 & $\begin{array}{l}300 \\
300 \\
300 \\
300 \\
300 \\
300 \\
300 \\
300 \\
300 \\
300 \\
300\end{array}$ & & $\begin{array}{l}1 \\
2\end{array}$ & \\
\hline $\begin{array}{l}\text { middle } \\
\text { Miocene }\end{array}$ & $\begin{array}{c}\text { Dictyocha } \\
\text { varia }\end{array}$ & & $\begin{array}{r}90 \\
1\end{array}$ & $\begin{array}{l}8 \\
\\
7 \\
2\end{array}$ & $\begin{array}{r}10 \\
31 \\
225 \\
218 \\
140 \\
180 \\
244 \\
111 \\
132 \\
221 \\
216 \\
128 \\
115 \\
224 \\
264 \\
265 \\
186\end{array}$ & $\frac{2}{1}$ & & & $\begin{array}{r}1 \\
5 \\
\\
5 \\
44 \\
9 \\
9 \\
15 \\
102\end{array}$ & & & & $\begin{array}{r}172 \\
42 \\
33 \\
54 \\
139 \\
106 \\
27 \\
54 \\
18 \\
56 \\
36 \\
17 \\
61 \\
24 \\
12 \\
12\end{array}$ & & 1 & 1 & $\begin{array}{l}8 \\
1\end{array}$ & 1 & & & & $\begin{array}{l}2 \\
1 \\
2\end{array}$ & $\begin{array}{l}300 \\
300 \\
300 \\
300 \\
300 \\
300 \\
300 \\
300 \\
155 \\
300 \\
300 \\
128 \\
133 \\
300 \\
300 \\
300 \\
300\end{array}$ & & $\begin{array}{l}2 \\
7 \\
2\end{array}$ & $\begin{array}{l}2 \\
3\end{array}$ \\
\hline
\end{tabular}


Table 8. Abundance of silicoflagellates and ebridians in selected samples from Hole 851B.

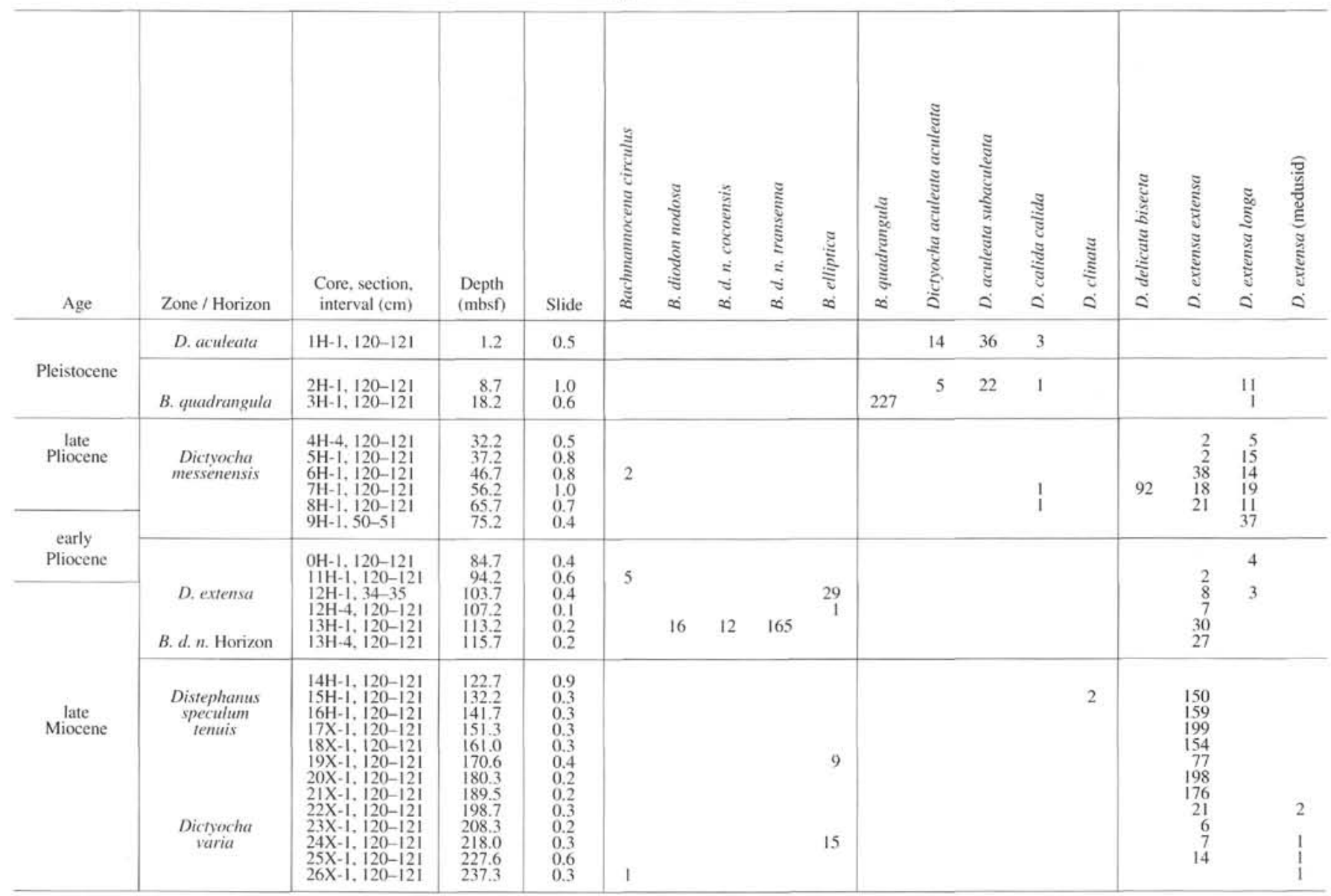

Note: Species (in alphabetical order) are recorded as total number of specimens found in the slides examined.

to draw attention to the changes in interpretation and to clarify the reasons for them.

\section{Silicoflagellates}

Genus BACHMANNOCENA Locker, 1974, emend. Bukry, 1987

$$
\text { Bachmannocena apiculata curvata (Bukry) Bukry }
$$

$$
\text { (PI. 4, Fig. 6) }
$$

Septamesocena apiculata (Schulz), Perch-Neilsen, 1975 (in part), p. 689, pl. 10, fig. 6 .

Mesocena apiculata (Schulz), Bukry, 1975c, p. 856, pl. 5, fig. 7.

Mesocena apiculata curvata Bukry, 1976b, p. 849, pl. 2, fig. 15, 16.

Bachmannocena apiculata curvata (Bukry), Bukry, 1987, p. 403.

Remarks: Two specimens of this taxon were found in Sample 138-844B$26 \mathrm{X}-4,120-121 \mathrm{~cm}$, and a single specimen in Sample 138-844B-25X-2. $120-121 \mathrm{~cm}$.

\section{Bachmannocena circulus (Ehrenberg) Bukry}

$$
\text { (PI. 4, Figs. I, 7; PI. 8, Fig. 7) }
$$

Mesocena circulus (Ehrenberg). Ehrenberg, 1844, p. 65. Bachmannocena circulus (Ehrenberg), Bukry, 1987, p. 404.

Remarks. B. circulus is a large, semi-circular skeletal structure displaying numerous small, pointed nodes along the outer margin of the ring. This taxon was generally uncommon, but consistently found in an interval from Sample $138-844 \mathrm{~B}-6 \mathrm{H}-4,120-12 \mathrm{~cm}$, to $-9 \mathrm{H}-4,120-121 \mathrm{~cm}$ and is extremely abundant in Sample 138-849B-15X-1, 120-121 cm.

\section{Introduction to the Bachmannocena/Neonaviculopsis Plexus}

Remarks. An extremely unusual collection of silicoflagellate morphologies was found in the late Miocene section of several Leg 138 sites. This plexus can be divided into two parts: (1) a group of morphologies closely associated with Bachmannocena diodon nodosa and (2) a group of larger, more elongate skeletons that have a naviculopsid morphology. The two groups appear to be closely related, but the latter group has a longer geologic range and a wider geographic distribution. Previous workers have placed members of this plexus in several genera. The approach used here was to consider several morphologies as forms of Bachmannocena diodon nodosa, and place the remaining morphologies into the separate genus Neonaviculopsis. The variety of unusual morphologies, exceptional abundance, and short geologic range of this plexus is similar to the pseudofibula plexus that has been documented from extremely high latitudes (McCartney and Wise, 1990; McCartney and Harwood, 1992) and that occurred at approximately the same time.

The Bachmannocena/Neonaviculopsis plexus occurs in a narrow acme in which the $B$. diodon nodosa morphologies, in particular, can be extremely abundant. The Bachmannocena morphologies include typical Bachmannocena diodon nodosa, consisting of only a basal ring, but others have a bridge that may be positioned anywhere along the length of the skeleton. Bukry (1982a, 1982b) divided this group between two Dictyocha species: D. navicula and D. transenna, while noting that specimens were similar to co-occurring Mesocena diodon nodosa in size and shape. We consider these morphologies to be forms of Bachmannocena diodon nodosa. This group is predominant in a narrow interval of the late Miocene section of sites near the equator.

Associated with the Bachmannocena diodon nodosa forms are similar and obviously closely related silicoflagellates that have a more elongate basal ring. The general shape is similar to the extinct Naviculopsis; in some cases, the bridge can be supported by short struts that result in a morphology similar to Dictyocha. Locker and Martini (1986b) placed these morphologies into the 
Table 8 (continued).

\begin{tabular}{|c|c|c|c|c|c|c|c|c|c|c|c|c|c|c|c|c|c|c|c|c|c|c|c|}
\hline 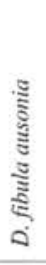 & 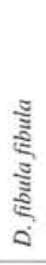 & 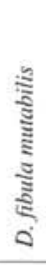 & 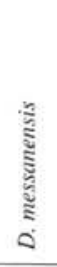 & 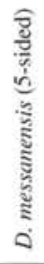 & 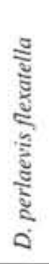 & 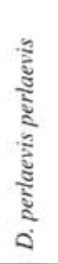 & 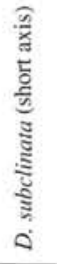 & 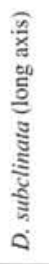 & $\begin{array}{l}\frac{g}{5} \\
\frac{5}{0}\end{array}$ & 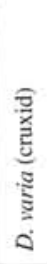 & 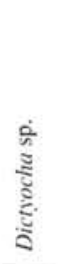 & 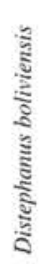 & $\begin{array}{l}\breve{J} \\
\text { है }\end{array}$ & 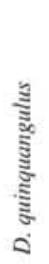 & 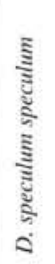 & 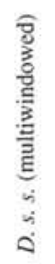 & 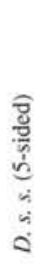 & 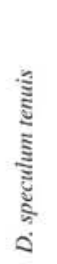 & 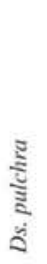 & 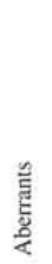 & 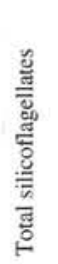 & 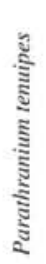 & 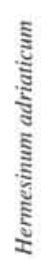 \\
\hline & & & 246 & & & & & & & & & & & & & & & & 1 & 300 & & & \\
\hline & 3 & & $\begin{array}{l}69 \\
27\end{array}$ & & 3 & $\begin{array}{c}35 \\
7\end{array}$ & & & & & 29 & 4 & & & 2 & & & & 3 & 3 & $\begin{array}{l}149 \\
300\end{array}$ & & \\
\hline 2 & $\begin{array}{c}10 \\
5 \\
2\end{array}$ & 1 & $\begin{array}{c}16 \\
23 \\
40 \\
7 \\
1 \\
2\end{array}$ & 1 & $\begin{array}{c}2 \\
3 \\
31 \\
14 \\
1\end{array}$ & $\begin{array}{c}7 \\
4 \\
20 \\
7 \\
4\end{array}$ & & & 51 & & $\begin{array}{c}22 \\
172 \\
134 \\
81 \\
37 \\
149\end{array}$ & $\begin{array}{l}6 \\
1\end{array}$ & & $\begin{array}{c}5 \\
67\end{array}$ & $\begin{array}{c}4 \\
17 \\
42 \\
19 \\
55\end{array}$ & 5 & $\begin{array}{c}1 \\
10 \\
3\end{array}$ & & & & $\begin{array}{c}60 \\
300 \\
300 \\
300 \\
100 \\
300\end{array}$ & & i \\
\hline $\begin{array}{l}3 \\
1 \\
9\end{array}$ & $\begin{array}{c}20 \\
18 \\
1 \\
11 \\
4\end{array}$ & & & & & $\begin{array}{l}3 \\
1\end{array}$ & & & $\begin{array}{c}3 \\
92 \\
11 \\
44 \\
2 \\
17\end{array}$ & & $\begin{array}{c}226 \\
168 \\
78 \\
2 \\
4 \\
2\end{array}$ & & $\begin{array}{l}4 \\
7 \\
3 \\
2 \\
1\end{array}$ & 1 & $\begin{array}{c}40 \\
34 \\
146 \\
41 \\
48 \\
49\end{array}$ & & & & & $\begin{array}{l}1 \\
1 \\
2 \\
4\end{array}$ & $\begin{array}{l}300 \\
300 \\
300 \\
100 \\
300 \\
100\end{array}$ & 2 & \\
\hline $\begin{array}{c}4 \\
91 \\
14 \\
3 \\
6 \\
15 \\
1 \\
\\
7\end{array}$ & $\begin{array}{l}15 \\
71 \\
43 \\
46 \\
58 \\
21 \\
2 \\
40 \\
20 \\
9 \\
1\end{array}$ & $\begin{array}{c}3 \\
1 \\
17 \\
10 \\
8 \\
1\end{array}$ & & & & $\begin{array}{c}125 \\
11 \\
5 \\
8 \\
2 \\
3\end{array}$ & 14 & 52 & $\begin{array}{c}1 \\
1 \\
1 \\
28 \\
9 \\
97 \\
972 \\
172 \\
114 \\
238 \\
153 \\
197\end{array}$ & 1 & & & $\begin{array}{c}2 \\
15 \\
2\end{array}$ & $\frac{1}{12}$ & $\begin{array}{c}111 \\
17 \\
18 \\
21 \\
18 \\
106 \\
68 \\
24 \\
62 \\
151 \\
28 \\
19 \\
96\end{array}$ & $\begin{array}{l}2 \\
2 \\
2 \\
1\end{array}$ & & $\begin{array}{c}38 \\
3 \\
15 \\
65 \\
7\end{array}$ & 1 & $\begin{array}{l}1 \\
2 \\
1 \\
1\end{array}$ & $\begin{array}{l}300 \\
300 \\
300 \\
300 \\
300 \\
300 \\
300 \\
300 \\
300 \\
300 \\
300 \\
300 \\
299\end{array}$ & & i \\
\hline
\end{tabular}

separate genus Neonaviculopsis. While we are reluctant to give this the status of a separate genus because of its obviously close relationship to the $B$. diodon nodosa forms, the morphologies are distinct enough that it is difficult to consider these as additional forms of $B$. diodon nodosa. The Neonaviculopsis group appears to range somewhat higher than the $B$. diodon nodosa variants and is more widespread geographically; Locker and Martini described the group from sediments situated more than $30^{\circ}$ south of the equator.

\section{Bachmannocena diodon diodon (Ehrenberg) Bukry}

(Pl. 4, Figs. 2, 8)

Mesocena diodon Ehrenberg, 1844, p. 71, 84.

Bachmannocena diodon (Ehrenberg), Bukry, 1987, p. 404.

Remarks. This taxon was relatively abundant in Samples 138-844B-9H-2, $120-121 \mathrm{~cm}$, and $-9 \mathrm{H} 4,120-121 \mathrm{~cm}$. It was not found in any other Leg 138 sites. $B$. diodon is a moderately sized, oval structure having two prominent distal spines. Unlike $B$. diodon nodosa, $B$. diodon diodon has a smooth ring surface.

Bachmannocena diodon nodosa (Bukry) Bukry

(Pl. 1, Fig. 1; Pl. 4, Fig. 2; Pl. 8, Figs. 1, 2, 9)

Mesocena diodon nodosa Bukry, 1978b, p. 818-819, pl. 5, figs. 14, 15; pl. 6, fig. 1-5.

Bachmannocena diodon nodosa (Bukry), Bukry, 1987, p. 404.

Remarks. This taxon is characterized by an elongate oval ring with two predominant spines aligned with the major axis and a surface ornamented with small nodes. It is abundant in a narrow horizon at near-equatorial sites, such as Sites 850 and 851 . Within this interval, it is associated with similar morphologies that have a bridge at varying points across the width of the basal ring.
Several specimens of Bachmannocena diodon nodosa found in the Pleistocene sediments of Sample 138-849B-3H-1, 130-131 cm, have pikes that extend from the inner basal ring. Specimens of $B$. diodon nodosa are considerably smaller than typical $B$. diodon diodon.

Bachmannocena diodon nodosa forma cocoensis (Bukry) n. comb. (Pl. 1. Fig. 4; Pl. 8. Fig. 7)

Dictyocha neonautica var. cocoensis Bukry, 1981a, p. 549, pl. 3, fig. 1-3. Dictyocha neonautica var. cocoensis Bukry, 1982a, p. 430.

Dictyocha neonautica Bukry, 1982b, p. 3I6, pl. 3, fig. 2.

Remarks. Bachmannocena diodon nodosa f. cocoensis here is restricted to those skeletons in which the bridge is near the midpoint between the two spined corners without being precisely at that point.

Authorship of n. comb. McCartney, Churchill, and Woestendiek.

Bachmannocena diodon nodosa forma neonautica $\mathrm{n}$. forma

Dictyocha navicula Ehrenberg. Bukry and Foster, 1973 (in part), p. 827, pl. 3. figs. 8 .

Dictyocha neonautica var. cocoensis Bukry, 1982a (in part), p. 430, pl. 3, fig. 9.

Dictyocha neonautica Bukry, 1982b (in part), p. 316, pl. 3, fig. 1.

Description. This taxon has an oval ring with two major-axis spines and a bridge across the minor axis without struts or minor-axis spines. The ring is of small size with an aspect ratio usually less that 2.0 , and is generally similar to co-occurring Bachmannocena diodon nodosa.

This taxon is considered to belong to Bachmannocena on the basis of that species' association and close relationship to $B$. diodon nodosa. Specimens that are more elongate are considered as Neonaviculopsis neonautica. Neonavicu- 
Table 9. Abundance of silicoflagellates and ebridians in selected samples from Hole 852B.

\begin{tabular}{|c|c|c|c|c|c|c|c|c|c|c|c|c|c|c|c|c|c|c|c|c|c|c|c|c|}
\hline Age & Zone & $\begin{array}{l}\text { Core, section, } \\
\text { interval }(\mathrm{cm})\end{array}$ & $\begin{array}{l}\text { Depth } \\
\text { (mbsf) }\end{array}$ & Slide & 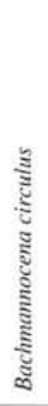 & 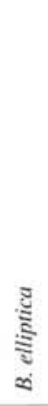 & 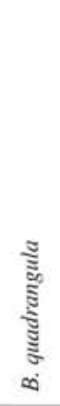 & 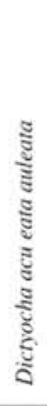 & 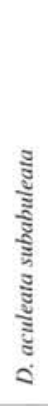 & 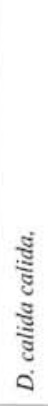 & 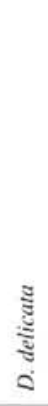 & 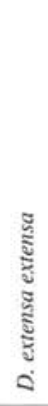 & 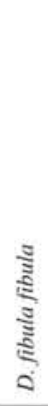 & 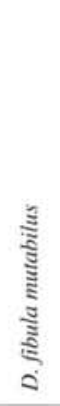 & 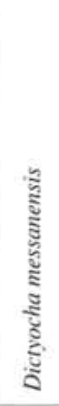 & 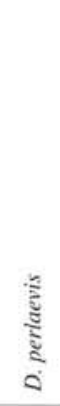 & 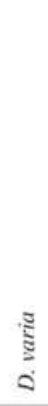 & 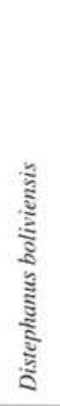 & $\stackrel{\dddot{y}}{5}$ & 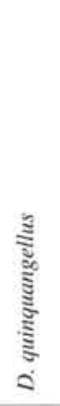 & 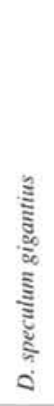 & 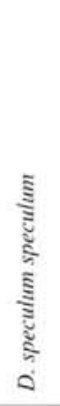 & 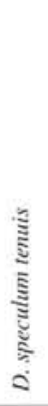 & 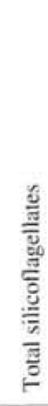 \\
\hline \multirow{2}{*}{ Pleistocene } & D. aculeata & $1 \mathrm{H}-1,120-121$ & 1.2 & 1.0 & & & & & & & & & & & 17 & & & & & & & & & 17 \\
\hline & B. quadrangula & $2 \mathrm{H}-1,120-121$ & 10.1 & 1.0 & 1 & & 29 & 2 & 1 & & & & & & 28 & 27 & & & & & & & & 90 \\
\hline $\begin{array}{c}\text { late } \\
\text { Pliocene }\end{array}$ & $\begin{array}{c}\text { Dictyocha } \\
\text { messanensis }\end{array}$ & $\begin{array}{l}3 \mathrm{H}-\mathrm{I}, 120-121 \\
4 \mathrm{H}-\mathrm{I}, 120-121\end{array}$ & $\begin{array}{l}19.6 \\
29.1\end{array}$ & $\begin{array}{l}1.0 \\
1.0\end{array}$ & & & & & & 1 & 3 & 80 & & & $\begin{array}{r}105 \\
7\end{array}$ & 38 & & & & 1 & 1 & 14 & & $\begin{array}{l}155 \\
138\end{array}$ \\
\hline $\begin{array}{c}\text { early } \\
\text { Pliocene }\end{array}$ & D. extensa & $\begin{array}{l}5 \mathrm{H}-1,120-121 \\
6 \mathrm{H}-1,120-121 \\
7 \mathrm{H}-1,116-117\end{array}$ & $\begin{array}{l}38.6 \\
48.1 \\
57.6\end{array}$ & $\begin{array}{l}1.0 \\
1.0 \\
1.0\end{array}$ & $\frac{2}{2}$ & & & & & & & $\begin{array}{l}10 \\
13\end{array}$ & $\begin{array}{l}1 \\
3 \\
2\end{array}$ & $\begin{array}{l}3 \\
3 \\
\end{array}$ & & 17 & 6 & & 1 & & & $\begin{array}{l}1 \\
2\end{array}$ & & $\begin{array}{r}3 \\
28 \\
45 \\
\end{array}$ \\
\hline \multirow[b]{2}{*}{$\begin{array}{c}\text { late } \\
\text { Miocene }\end{array}$} & Ds. s. tenuis & $8 \mathrm{H}-1,119-120$ & 67.1 & 1.0 & 2 & & & & & & & 10 & 3 & 49 & & 96 & & & 7 & 7 & & 16 & 5 & 193 \\
\hline & $\begin{array}{l}\text { Dictyocha } \\
\text { varia }\end{array}$ & $\begin{array}{l}9 \mathrm{H}-1,50-51 \\
10 \mathrm{H}-1,120-121 \\
11 \mathrm{H}-1,120-121 \\
12 \mathrm{H}-1,120-121\end{array}$ & $\begin{array}{r}76.6 \\
86.1 \\
95.6 \\
105\end{array}$ & $\begin{array}{l}0.9 \\
1.0 \\
1.0 \\
1.0\end{array}$ & $\begin{array}{l}2 \\
1\end{array}$ & 6 & & & & $\begin{array}{l}3 \\
5\end{array}$ & & $\begin{array}{r}69 \\
13 \\
25 \\
1\end{array}$ & $\begin{array}{r}27 \\
6 \\
18\end{array}$ & $\begin{array}{r}5 \\
225 \\
22\end{array}$ & & $\begin{array}{r}147 \\
33\end{array}$ & $\begin{array}{l}10 \\
53\end{array}$ & $\begin{array}{r}3 \\
3 \\
13 \\
4\end{array}$ & $\frac{1}{2}$ & 3 & $\begin{array}{l}1 \\
1 \\
2\end{array}$ & 50 & & $\begin{array}{r}300 \\
168 \\
130 \\
60\end{array}$ \\
\hline
\end{tabular}

Note: Species (in alphabetical order) are recorded as total number of speicmens found in the slides examined. 
Table 10. Abundance of silicoflagellates and ebridians in selected samples from Hole 854B.

\begin{tabular}{|c|c|c|c|c|c|c|c|c|c|c|c|c|}
\hline Age & Zone & $\begin{array}{l}\text { Core, section, } \\
\text { interval }(\mathrm{cm})\end{array}$ & $\begin{array}{l}\text { Depth } \\
\text { (mbsf) }\end{array}$ & Slide & 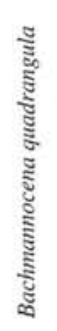 & 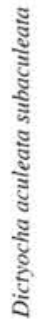 & 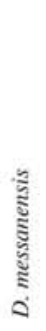 & 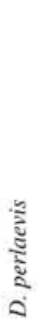 & 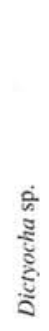 & 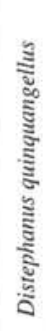 & 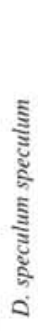 & 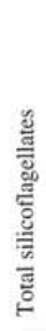 \\
\hline \multirow{4}{*}{ Pleistocene } & D. aculeata & $\mathrm{H}-1,120-121$ & 1.2 & 0.5 & & $1 ?$ & & 1 & & & & 2 \\
\hline & B. quadrangula & $\mathrm{H}-4,120-121$ & 5.7 & 0.6 & 242 & 4 & 39 & 15 & & & & 300 \\
\hline & $\begin{array}{c}\text { Dictyocha } \\
\text { messannensis }\end{array}$ & $\begin{array}{l}2 \mathrm{H}-1,120-12 \mathrm{I} \\
2 \mathrm{H}-4,120-121\end{array}$ & $\begin{array}{r}9.6 \\
14.1\end{array}$ & $\begin{array}{l}1.0 \\
1.0\end{array}$ & 4 & & $\begin{array}{r}7 \\
13\end{array}$ & 85 & $\begin{array}{r}19 \\
5\end{array}$ & 3 & $\begin{array}{l}4 \\
1\end{array}$ & $\begin{array}{r}122 \\
19\end{array}$ \\
\hline & Unzoned & $\begin{array}{l}3 \mathrm{H}-1,120-121 \\
4 \mathrm{H}-1,120-121 \\
5 \mathrm{H}-1,120-121\end{array}$ & $\begin{array}{l}19.1 \\
28.6 \\
38.1\end{array}$ & $\begin{array}{l}0.5 \\
0.3 \\
0.3\end{array}$ & & $\begin{array}{l}\mathrm{B} \\
\mathrm{B} \\
\mathrm{B}\end{array}$ & $\begin{array}{l}\mathrm{A} \\
\mathrm{A} \\
\mathrm{A}\end{array}$ & $\begin{array}{l}R \\
R \\
R\end{array}$ & $\begin{array}{l}\mathrm{R} \\
\mathrm{R} \\
\mathrm{R}\end{array}$ & $\begin{array}{l}E \\
E \\
E\end{array}$ & $\begin{array}{l}\mathrm{N} \\
\mathrm{N} \\
\mathrm{N}\end{array}$ & $\begin{array}{l}0 \\
0 \\
0\end{array}$ \\
\hline
\end{tabular}

Note: Species (in alphabelical order) are recorded as total number of specimens found in the slides examined.

lopsis neonautica differs from this taxon in being more elongate and of generally larger size. The morphology is polyphyletic, since aberrants of Dictyocha fibula (McCartney and Wise, 1987) and D. mutabilis (Deflandre, 1950) are known to adopt a similar design.

Type specimen. The specimen illustrated in Plate 3, figure 9, of Bukry (1982a) is here designated as the type.

Authorship of n. forma. McCartney, Churchill, and Woestendiek.

Bachmannocena diodon nodosa forma transenna (Bukry) n. comb. (PI. 1, Figs. 2, 3)

Dictyocha transenna Bukry, 1982b, p. 315, pl. 4, fig. 1-12; pl. 5, fig. 1,2.

Remarks. Bukry (1981a, 1982a, 1982b) considered these unusual bridged morphologies to be members of the genus Dictyocha, but because these are obviously closely related to Bachmannocena diodon nodosa and distinct from other Dictyocha, they are here considered as varieties of $B$. diodon nodos $a$. The occurrence of bridged varieties of Bachmannocena is further evidence of the plasticity of the silicoflagellate skeleton and of the close phylogenetic relationships that may exist among separate genera of the current taxonomy.

This taxon has enormous variability, with the bridge occurring anywhere between the $B$. diodon nodosa and the $B$. diodon nodosa f. neonautica endmembers. Bukry (1982b) informally divided this range of variation into three groups, which he designated as Types A, B, and C, depending on the relative position of the bridge, but has not used these subdivisions in subsequent work. Bukry (1983, pl. 9, fig. 9-12) also found transennid variants of Bachmannocena quadrangula.

Authorship of n. comb. McCartney, Churchill, and Woestendiek.

Bachmannocena diodon triodon (Bukry) n. comb.

Mesocena triodon Bukry, 1978b, pp. 819-820, pl. 7, figs. 9, 10.

Remarks. Commonly associated with Bachmannocena diodon are specimens having a third spine. The position of the third spine varies, but it is usually smaller than the two spines that occur at opposite ends of the major axis. While this interesting skeletal morphology has previously been given species rank, it is here recombined to show its biological relationship to Bachmannocena diodon, as previously advocated informally by McCartney and Wise (1987) .

\section{Bachmannocena elliptica (Ehrenberg) Bukry}

Dictyocha (Mesocena) elliptica Ehrenberg, 1840, p. 208; Ehrenberg, 1854, pl. 20(1), fig. 44a, 44b.

Mesocena elliptica (Ehrenberg), Bukry 1978b, p. 819, pl. 6, figs. 6-13.
Bachmannocena elliptica (Ehrenberg), Bukry, 1987, p. 404.

Remarks. Bukry and Foster (1973) noted that there appeared to be two groups of four-sided mesocenids, one in the Miocene and another in the Quaternary; they referred to both of these as M. elliptica. Bukry (1978b, p. 819), reduces M. elliptica to small, smooth, specimens most common in the Miocene; upper Miocene to Quaternary specimens having a noded ornamentation on the basal ring are referred to as $M$. quadrangula. Bachmannocena elliptica were relatively common in a narrow interval from the middle Miocene section of Hole 844B.

Bachmannocena quadrangula (Ehrenberg ex Haeckel) Bukry (Pl. 4, Fig. 3; Pl. 8, Fig. 5)

Mesocena quadrangula Ehrenberg ex Haeckel, 1887, p. 1556, Lemmermann, 1901, pl. 10, figs. 5-7, fide Loeblich et al., 1968, p. 57.

Mesocena quadrangula Ehrenberg ex Haeckel, Bukry, 1978b, p. 819, pl. 7. figs. 1-5.

Bachmannocena quadrangula (Ehrenberg ex Haeckel), Bukry, 1987, p. 405.

Remarks. Bachmannocena quadrangula differs from B. elliptica in having a more quadrate form with more equant spines and a more noded surface. This taxon is extremely abundant in a narrow interval of the late Pliocene. Specimens with three or five basal spines occur infrequently.

\section{Genus CORBISEMA Hanna, 1928}

Corbisema triacantha (Ehrenberg) Bukry and Foster

(Pl. 4, Figs. 4, 5)

Dictyocha triacantha Ehrenberg, 1844, p. 80.

Corbisema triacantha (Ehrenberg), Bukry and Foster, 1974, p. 305, fig. le.

Remarks. This taxon marks the Corbisema triacantha Zone and was often very abundant in the early and middle Miocene sections of Hole 844B.

\section{Genus DICTYOCHA Ehrenberg, 1837}

Dictyocha aculeata aculeata (Lemmermann) Dumitrica (PI. 9, Fig. 2)

Dictyocha fibula var. aculeata Lemmermann, 1901, p. 261, pl. 11, figs. 1, 2 . Dictyocha epiodon Ehrenberg, Bukry and Foster, 1973, pl. 2, fig. 7-8.

Dictyocha aculeata (Lemmermann), Dumitrica, 1973, p. 849, pl. 4, fig. 9-11. Dictyocha mandrai Ling. 1977, p. 209, pl. 1, figs. 13, 14. 
Dictyocha aculeata aculeata (Lemmermann), Bukry, 1980b, p. 549.

Remarks. This distinctive Quaternary silicoflagellate is considered by Gemeindhardt (1930; see Dumitrica, 1973, p. 907) as a warm-water species. Dumitrica's (1973) discussion includes measurements made of two varieties. large and small. Locker and Martini (1986b) considered this taxon to be within the variation of D. messanensis; we consider Dictyocha aculeata as a separate species on the basis of its generally larger size and more robust appearance.

Dictyocha aculeata subaculeata Bukry

Dictyocha aculeata subaculeata Bukry, 1980b, p 552, pl. 1, fig. 8-17.

Remarks. Dictyocha aculeata subaculeata here is distinguished from $D$. aculeata aculeata by having more linear sides and less pronounced pikes: it also commonly has a bridge that is less canted and of longer length relative to $D$. aculeata aculeata. This taxon is seen as an evolutionary intermediate between $D$ aculeata aculeata and D. messanensis.

The microscopist for Holes $844 \mathrm{~B}$ and $847 \mathrm{~B}$ (Woestendiek) had some difficulty in distinguishing between $D$. aculeata subaculeata and $D$. aculeata aculeata, so the counts listed in Tables 3 and 4 for these taxa should not be taken as absolutely correct. Although Locker and Martini (1986b) consider this as a subspecies of $D$. messanensis, we consider Dictyocha aculeata as a separate species on the basis of its generally larger size and more robust appearance.

\section{Dictyocha angulata Bukry}

$$
\text { (Pl. 9, Fig. 5) }
$$

Dictyocha angulata Bukry, 1982a, p. 431, pl. 1, figs. 9-12; pl. 2, fig.1 .

Remarks: Dictyocha angulata is scattered throughout Hole 849B but was not recognized elsewhere in this study.

\section{Dictyocha calida ampliata Bukry}

(PI. 9, Fig. 1)

Dictyocha calida ampliata Bukry, 1979b, p. 982, pl. 2, figs. 1, 2, 9.

Remarks. A single specimen of this unusual morphology with incised sides was found in $-851 \mathrm{~B}-4 \mathrm{H}-4,120-121 \mathrm{~cm}$. and was found scattered in several samples in Hole 847B, from the Bachmannocena quadrangula Zone to the middle of the Dictyocha extensa Zone.

\section{Dictyocha calida calida Poelchau}

Dictyocha calida Poelchau, 1976, p. 169, pl. I, fig. c, d; pl. 3, fig. a-f. Dictyocha calida calida Poelchau, Bukry, 1979a, p. 560, pl. 1, fig. 7.

Remarks. Dictyocha calida is characterized by a square basal ring having long equant spines and a short bridge. The taxon is abundant in oligotrophic waters of the modern Pacific Ocean (Poelchau, 1974, 1976), but is unusual in Leg 138 samples.

\section{Dictyocha clinata (Bukry) n. comb.} (PI. 9, Fig. 4)

Dictyocha aspera clinata Bukry, 1975a, p. 687, pl. 1, figs. 1-5.

Remarks. This taxon is characterized by a middle-to large-sized basal ring with a bridge that is canted with respect to the minor axis. It is generally smaller, somewhat more robust and often has longer basal spines than co-occurring Dictyocha fibula, and is thus listed here as a separate taxon. D. clinata generally occurs in the late Miocene section but was found in the middle Miocene of Hole 844B.

Authorship of n. comb. McCartney, Churchill, and Woestendiek.

Dictyocha delicata bisecta (Bukry) n. comb.

(PI. 2, Fig. 6; Pl. 5, Fig. 6; PI. 9, Figs. 7-8)

Dictyocha perlaevis delicata Bukry, 1976c, p. 724, pl. 1, figs. 5-10.

Dictyocha delicata (Bukry), Bukry, 1982a, p. 432, pl. 2, fig. 7.

Dictyocha delicata var. bisecta (Bukry), Bukry, 1983, p. 329, pl. 3, figs. 2-4.

Remarks. This taxon has a mid-sized basal ring with an apical structure made of thin skeletal elements. This morphology is abundant in Sample $138-851 \mathrm{~B}-7 \mathrm{H}-1,120-121 \mathrm{~cm}$. The Dictyocha delicata specimens in this sam- ple are distinctly smaller than the co-occurring $D$. perlaevis and have a bridge that extends across most of the length of the basal ring.

This taxon also occurs in Samples 138-850B-12X-4, 120-121 cm, and $-850 \mathrm{~B}-13 \mathrm{X}-1,120-121 \mathrm{~cm}$ and was found scattered in Hole 847B; the specimens in these samples are similar to the co-occurring Bachmannocena quadrangula in size and surface ornamentation. However, there were not enough specimens to demonstrate a phyletic relationship. Four specimens were observed in Sample 138-649B-16X-1, 120-121 cm.

Authorship of n. comb. McCartney, Churchill, and Woestendiek.

\section{Dictyocha extensa extensa (Locker) Locker and Martini} (PI. 3, Figs. 2-5; PI. 5, Figs. 3, 7; PI. 8, Fig. 8)

Dictyocha varia f. extensa Locker, 1975, p. 99-101, figs. I/2, 3/3.

Dictyocha extensa (Locker), Locker and Martini, 1986b, p. 903-904, pl. 2, figs. 10-12; pl. 11, fig. 3 .

Remarks. In his original description, Locker believed this taxon was conspecific with $D$, varia. The close similarities in the size and shape of the basal ring, as well as the frequent co-occurrence with $D$. varia in the current study, lend support to this interpretation; however, it is listed as a separate species in order to be consistent with Locker's more recent usage. D. extensa ranges higher than $D$. varia. The change from $D$. varia to $D$. extensa marks the "aspera/fibula" transition that has been commented on by various workers (see Bukry, 1982b) and that Burckle (1981) placed in the lower part of Magnetic Epoch 7 (late Miocene).

In this study, Dictyocha extensa extensa was restricted to specimens that had a basal ring that was rounded at the major-axis corners. These specimens have a basal ring similar to that of typical $D$. varia. Specimens having pointed basal corners thus had a rhomboid rather than oval shape to the basal ring and were counted as Dictyocha sp. There appears to have been a change in the shape of the basal ring during the course of the Pliocene, and this change is partly reflected in the increasing abundance of Dictyocha sp.

The phylogenetic relationships between $D$. extensa and $D$. varia, as seen by the first author, are illustrated in Figure 4 . The similarities in basal ring size, spine lengths, and the robustness of basal and apical elements suggests to us that these two taxa are closely related by evolution. It is possible, we believe, that these two morphotypes represent different parts of a single range of variation within a species, with the minor-axis bridge (D. varia) predominating in the late Miocene and the major-axis morphology ( $D$. extensa) in the early Pliocene; this hypothesis certainly warrants testing. This close relationship is further suggested by the abundance of deflandroid variants of both taxa in Sample 138-844B-28X-2, 120-121 cm. However, there are other points of view. Locker (personal communication) sees these separate morphologies as representing distinct species, and suggests that a bifurcation into separate lineages would be better than the single lineage illustrated in figure 4 . Such questions deserve careful study and may yield much information on silicoflagellate variability and evolution.

Five-sided specimens of $D$. extensa extensa were found in Samples 138$848 \mathrm{~B}-6 \mathrm{H}-4,120-121 \mathrm{~cm},-850 \mathrm{~B}-19 \mathrm{X}-1,120-121 \mathrm{~cm},-85$ । B-26X-1, 120-121 $\mathrm{cm}$, and $-851 \mathrm{~B}-30 \mathrm{X}-1,120-121 \mathrm{~cm}$.

Silicoflagellates counted as Dictyocha extensa extensa (medusid) are characterized by an apical structure in which the four struts meet at a precise point. Those specimens in which the four struts form a very short bridge (see Locker and Martini, 1986b, pl. 2, figs. 14, 15; pl. 11, fig. 6) were counted as D. extensa or D. varia, depending on the orientation of the bridge. The decision to place this form in Dictyocha extensa, rather than D. varia, is arbitrary. Medusid variants of $D$. extensa (pl. 5, fig. 7) were relatively abundant in Hole 844B.

\section{Dictyocha extensa longa (Bukry) n. comb.}

$$
\text { (PI. 5, Fig. 10) }
$$

Dictyocha perlaevis perlaevis Frenguelli, Bukry, 1980b (in part), p. 553, pl. 4, figs. 10-13.

Dictyocha longa Bukry, 1982a, p. 432, pl. 2, figs. 8-13, pl. 3, figs. 1,2.

Remarks. Bukry (1982a) described this taxon as having a somewhat elongate basal ring of moderate-size with an apical structure that has an I-shaped appearance. Specimens found in Leg 138 samples are similar to $D$. extensa extensa, but generally possess a longer apical bridge. The angles between the bridge and the struts, as seen from apical view, are significantly less than $120^{\circ}$. The relative abundance of $D$. extensa longa, seen in this study, is less than that observed by Bukry (1982a, 1982b, 1983), suggesting that some 
of the range of variation counted as $D$. longa by Bukry in this study were placed within D. extensa extensa or Dictyocha sp.

Authorship of n. comb. McCartney, Churchill, and Woestendiek.

\section{Introduction to Dictyocha fibula}

Considerable disagreement has evolved about the use of the term "Dictyocha fibula." During the early DSDP legs (e.g., Martini, 1971, 1976; Ling, 1975, Bukry and Foster, 1973) the term was applied to a wide range of skeletal morphologies having an apical bridge parallel to the major axis. The term "Dictyocha aspera" similarly was applied to a wide range of skeletal morphologies having a bridge parallel to the minor axis. These usages developed partly from Lemmermann (1901), who gave the names D. fibula var. aspera and Dictyocha fibula var. brevispina to two of Ehrenberg's specimens that had bridges parallel to the minor axis. Bukry and Foster (1973) and Bukry (1976c) elevated these to species status and restricted the usage of $D$. fibula to morphologies that had a bridge parallel to the long axis.

More recently, the wide morphologic range of $D$. fibula (as used by Bukry and Foster) has been reduced with the application of D. aculeata, D. messanensis (or D. stapedia), D. perlaevis, D. longa, and other terms that have been applied to four-sided silicoflagellates with bridges parallel to the major axis. In the more recent deep-sea literature, $D$. fibula came to be used for skeletons that could not easily be placed in the developing taxonomy (e.g., Bukry, 1983, 1984; McCartney and Wise, 1990).

While $D$. fibula has been applied to skeletons having long-axis bridges by most workers that have contributed to the silicoflagellate deep-sea literature, the taxon has been used differently by Sigurd Locker and Erlend Martini. Locker (1974) reexamined Ehrenberg's type specimens and designated a large equant four-sided skeleton having a bridge parallel to the shorter spines as the lectotype for $D$. fibula. This specimen, which came from the middle Miocene of Oran in Algeria is similar to specimens illustrated by Lemmermann (1901) and Schulz (1928) as D. fibula var. brevispina and var. aspera. Thus, D. brevispina and $D$. aspera have become junior synonyms of $D$. fibula, and Locker and Martini (1986b; Martini and Müller, 1976; Martini, 1990) have built up a taxonomy based on $D$. fibula's being a large, four-sided silicoflagellate with bridge parallel to the minor axis.

In previous work by the first author (see the discussion in McCartney and Harwood, 1992), the usage of "Dictyocha fibula s. 1." was retained so that the work could be easily compared to the voluminous Bukry literature. However, here we accept the Locker usage for $D$. fibula and hope that this can be used as a basis for developing some standardization of silicoflagellate taxonomy. The taxon is applied to a group of medium- to large-sized silicoflagellates having a bridge that normally is parallel to the minor axis, and here has been divided into three subspecies. Because the terms "aspera" and brevispina now are considered junior synonyms, they are here replaced by "fibula" and mutabilis, respectively.

Dictyocha fibula ausonia (Deflandre) n. comb.

(Pl. 2, Figs. 2-4; Pl. 3, Fig. 11; Pl. 5, Fig. 4)

Dictyocha ausonia Deflandre, 1950, p. 195, fig. 194-196, 199-202.

Dictyocha brevispina ausonia (Deflandre), Bukry, 1978a, p. 697, pl. 1, figs. $17-19$.

Remarks. Dictyocha fibula ausonia is characterized by an elliptical basal ring that is rounded at the major-axis corners and differs from $D$. fibula fibula, which has a more pointed major axis corner. The relationship between these two taxa appears to vary; in some samples, they are similar, except for the outline of the basal ring; while in other samples, the two are more distinctly different, with $D$. fibula ausonia usually having a smaller size than co-occurring D. fibula fibula.

The counts for Sample 138-844B-3IX-5, 92-93 cm include three specimens that lack struts and have a bridge that is offset from the minor axis ( $\mathrm{Pl}$. 2, Fig. 4); similar specimens have been illustrated by Bukry (1980a, pl. 1, figs. 11-13). Bukry's specimens are of similar age.

Authorship of n. comb. McCartney, Churchill, and Woestendiek.

\section{Dictyocha fibula fibula Ehrenberg}

$$
\text { (Pl. 2, Fig. 1: Pl. 5, Fig. 5) }
$$

Dictyocha fibula Ehrenberg, Locker, 1974, p. 636, pl. 1, fig. 6 (= lectotype). Dictyocha fibula fibula Ehrenberg, Locker and Martini, 1986b, p. 904, pl. 5, figs. 1,2 ; pl. 11, figs. 8,9 .

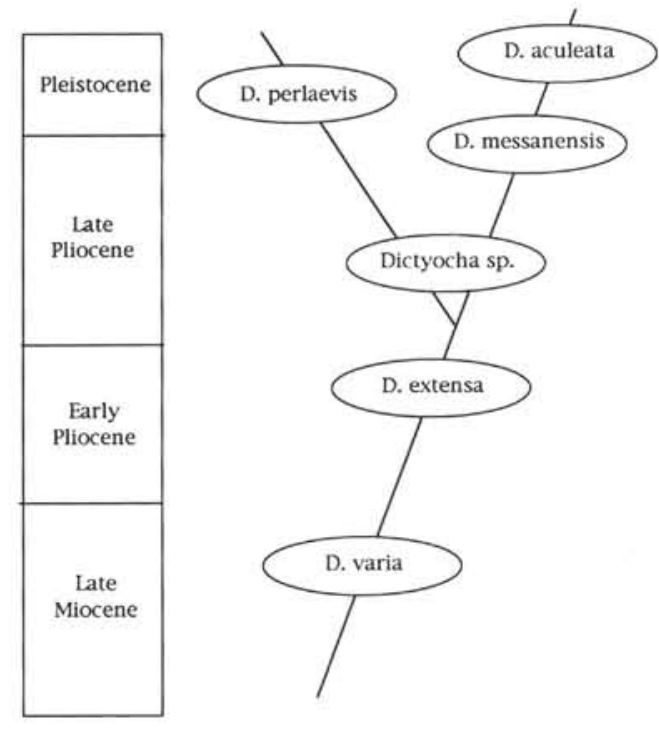

Figure 4. Simplified phylogeny showing the evolutionary relationships of important Dictyocha taxa as interpreted from Leg 138. Dictyocha sp. is a complex collection of intermediates between D. extensa, D. messanensis, and D. perlaevis.

Remarks. This is a group of generally large-sized dictyochid silicoflagellates having the bridge parallel to the minor axis and is commonly abundant in Miocene sediments of low and middle latitudes. The group has considerable diversity which workers have dealt with in a variety of ways. Skeletons having a relatively long bridge often have been generally classified as Dictyocha brevispina, while those having a shorter bridge usually have been classified as D. aspera, or sometimes in the older deep-sea literature (Bukry, 1973, 1975b), D. rhombica. In this study, we accept Locker's (1974) designation of a large skeleton with a long-axis bridge as the lectotype for $D$. fibula.

\section{Dictyocha fibula mutabilis (Deflandre) n. comb.}

Dictyocha mutabilis Deflandre, 1950, pl. 18, figs. 7-14.

Dictyocha brevispina (Lemmermann), Bukry, 1976c, p. 723.

Dictyocha brevispina brevispina (Lemmermann), Bukry, 1978b, p. 816, pl. 2, figs. 9,10 .

Remarks. Dictyocha fibula mutabilis here is used for skeletal morphologies that have previously been commonly referred to as $D$. brevispina. The basal ring of this taxon is somewhat more elongate than that of typical $D$. fibula fibula.

Authorship of n. comb. McCartney, Churchill, and Woestendiek.

\section{Dictyocha lingii Dumitrica}

Dictyocha lingi Dumitrica, 1973, p. 906, pl. 8, figs. 1-7.

Dictyocha lingii Dumitrica, Bukry, 1979a, p. 983, pl. 2, figs. 5-8.

Remarks. A single specimen similar to those illustrated by Bukry (1980b, pl. 3, figs. 3-5) was found in Sample 138-848B-6H-1, 120-121 cm.

\section{Dictyocha messanensis Haeckel}

(Pl. 3, Figs. 12-13)

Dictyocha fibula var. b Ehrenberg, 1843, p. 312, pl. 2, fig. IV 11.

Dictyocha messanensis Haeckel, in Peters (1860), p. 799-800.

Remarks. This taxon has considerable variability in the shape of its basal ring, the robustness of the skeletal elements and in the presence or absence of an apical spine. Locker and Martini (1986b) and other workers divided this taxon into several subspecies and forms, but these distinctions were found difficult to apply consistently, and thus, this taxon was not subdivided in this study. 
Dictyocha perlaevis flexatella Bukry (PI. 2, Fig. 8)

Dictyocha perlaevis flexatella Bukry, 1979a, p. 984, pl. 3, figs. I-3.

Remarks. This taxon is generally rare, but is abundant in Sample 138$850 \mathrm{~B}-6 \mathrm{H}-4,120-121 \mathrm{~cm}$.

\section{Dictyocha perlaevis ornata Bukry}

(PI. 2, Fig. 6)

Dictyocha perlaevis ornata Bukry, 1977. p. 922, pl. I, figs. 1-6; Bukry, 1978c. p. 644, pl. 1. fig. 8: Bukry, 1979a, p. 561,pl. 2, figs. 11-14.

Remarks. Dictyocha perlaevis ornata is found in Sample 138-849B-18X1. $120-121 \mathrm{~cm}$. A specimen found in Sample 138-849B-5H-1, 120-121 cm, was probably reworked.

\section{Dictyocha perlaevis perlaevis Frenguelli} (PI. 5, Fig. I; PI. 8, Fig. 4; PI. 9, Fig. 3)

Dictyocha perlaevis Frenguelli, 195I, p. 279, figs. 4b, 4c.

Dictyocha fibula perlaevis (Frenguelli), Bukry, 1975c, p. 855, pl. 3, fig. 5.

Dictyocha perlaevis perlaevis Frenguelli, Bukry, 1979a, p. 984, pl. 3, fig. 6-11.

Remarks. Dictyoch a perlaevis is most readily recognized by its large size. Smaller specimens that were otherwise similar to D. perlaevis were counted as Dictyocha sp.

Dictyocha subclinata Bukry

$$
\text { (PI. 1, Figs. 5, 6, 8; PI. 5, Figs. 8, 9) }
$$

Dictyocha sp., Ling, 1972 (in part), p. 164, pl. 26, figs. 7 and 8.

Dictyocha subclinata Bukry, 1981a, p. 546, 547, pl. 1, figs. 4-8; pl. 2, Figs. 1-10.

Remarks. This taxon is characterized by a moderate-sized apical bridge that is slightly inclined with respect to either the major or minor axis. The basal ring has long major-axis and short minor-axis spines. Both major- and minoraxis varieties are common in a brief interval of the early late Miocene, in Samples 138-850B-33X-1 $120-121 \mathrm{~cm}$., and $-851 \mathrm{~B}-25 \mathrm{X}-1,120-121 \mathrm{~cm}$. The group appears to be less abundant over a longer interval in DSDP Site 472 (Bukry, 198Ia)

Dictyocha tamerae Bukry

Dictyocha tamerae Bukry, 1983, p. 338, figs. 7-11.

Dictvocha varia Locker

(PI. 3, Fig. 1; PI. 5, Fig. 2; PI. 8, Fig. 6)

Dictyocha varia Locker, 1975, p. 99-101, figs. 3-7.

Dictyocha pulchella Bukry, 1975a, p. 687, pl. 4, figs. 1-3.

Remarks. This taxon has taken on two names in the DSDP and ODP literature. Bukry (1982a, 1982b, 1983) uses Dictyocha pulchella, while Locker and Martini (1986b) refer to it as Dictyocha varia; both terms were first described in 1975. Priority here is given to the Locker taxon, since it was described earlier in the year.

Dictyocha varia typically is small with a short-axis bridge, elliptical basal ring, and a generally robust construction. As the name suggests, considerable variation, particularly in the general size, exists in the shape of the basal ring and the structure of the apical axis. Major-axis morphologies that are similar to D. varia in the size and shape of the basal ring originally were described as D. varia forma extensa; this taxon has since been elevated to the species level. Cruxoid and deflandroid variants also can be common.

\section{Introduction to Dictyocha sp.}

Bukry (1982a, 1982b, 1983), in his investigations of silicoflagellates from equatorial sites, found abundant upper Miocene and lower Pliocene specimens of what he termed "Dictyocha fibula s. ampl." Bukry did not include photographs of this group but stated (Bukry, 1983) that Figures 8 and 9 of Loeblich et al. (1968) were used as a species concept for this taxon. These illustrations from Loeblich, which were reprinted from Ehrenberg, closely resemble Dictyocha extensa. However, Bukry"s use of "s. ampl." and his reluctance to describe a new species suggest a group of Dictyocha with long-axis bridges that are not easily classified. We interpret a similar group, referred to as Dictyocha sp., in our investigations of Leg 138.

This group of Dictyocha are not readily amenable to species-level classification because of their wide variety, which is inconsistent enough from one sample to the next that it is difficult to apply a single set of identifying criteria. These generally middle-sized silicoflagellates frequently appear as intermediates between various species of the well-established Dictyocha, particularly $D$. perlaevis, $D$. messanensis, and $D$. extensa; this makes the interpretation into separate species a difficult undertaking. These skeletons were counted as Dictyocha sp. after several taxonomic approaches applied to this problem failed to separate the Dictyocha into distinct species that could be consistently identified.

The broad group of silicoflagellate morphologies represented here by Dictyocha sp. differs somewhat from Bukry's Dictyocha fibula s. ampl., although both groupings probably reflect similar difficulties in separating the Dictyocha into readily identifiable species. Bukry described (1982b) and used the taxon Dictyocha perfecta, which we were unable to recognize and apply consistently in our study. On the other hand, Bukry did not recognize $D$. extensa, which we counted as a separate species. Thus, Bukry's grouping includes $D$. extensa, while our grouping includes $D$. perfecta.

A possible explanation for this grouping is hybridization between several closely related species. Two important silicoflagellate species, D. perlaevis and D. messanensis, evolved during the interval in which the Dictyocha sp. morphologies are abundant. These species are distinct in the late Pliocene and Pleistocene sections, but appear to be less so in lower strata. Both taxa apparently evolved from $D$. extensa, which become less predominant and more variable in the interval in which Dictyocha sp. is abundant (Fig. 4).

\section{Dictyocha sp.}

$$
\text { (PI. 3, Figs. 6-10) }
$$

Remarks. This is a broad group of dictyochids with a bridge parallel to the major axis, or slightly inclined from it. The group can best be understood as a collection of intermediates between $D$. extensa, D. messanensis, and D. perlaevis. Both the size and the shape of the basal ring vary considerably, but typical specimens are small to middle-sized. This grouping includes $D$. perfecta (Bukry, 1982b; 1983), but the boundaries between $D$. perfecta and other somewhat similar morphologies were difficult to place and varied from one sample to another, which made the broader grouping of Dictyocha sp. necessary.

\section{Genus DISTEPHANUS Stöhr, 1880}

Distephanus boliviensis boliviensis (Frenguelli) Bukry and Foster (Pl. 6, Fig. 1; PI. 10, Fig. 1)

Dictyocha boliviensis Frenguelli, 1940 (in part), p. 44, fig. 4a. Distephanus boliviensis boliviensis (Frenguelli). Bukry, 1979a, p. 985, pl. 4, fig. 12; pl. 5, fig. 1.

Remarks: Two specimens were found in Hole 844B that had an apical ring of moderate size subdivided into four small, rounded, symmetrical openings (PI. 3, Fig. 1). These are listed in the counts as D. boliviensis (multiwindowed).

\section{Distephanus crux carolae Bukry}

$$
\text { (PI. 2, Figs. 7, 8) }
$$

Distephanus crux carolae Bukry, 1982b, p. 315, pl. 5, figs. 4-11; Bukry, 1983. pl. 7, fig. 3 .

Remarks. This taxon is small and has generally equant sides and long basal spines. The apical ring is square and has a small window. The apical structure often has a short bridge instead of an apical window; the bridge can be parallel to the major or minor axes. Bukry (1983) recorded this as a rare taxon over a large interval in the lower Pliocene and upper Miocene sediments of Hole 503A. but more abundant over a short interval of the lower Pliocene. Bukry (1982b) also found both ringed and bridged variants in Sample 68-503A-41-1, 34-35 $\mathrm{cm}$, which is late Miocene in age. In the present study, this taxon occurs in Sample 138-850B-16H-1, 120-121 cm; the counts recorded in Table 3 include one specimen having a bridge.

\section{Distephanus crux crux Ehrenberg}

(PI. 7. Figs. I, 2, 5, 8, 9)

Distephanus crux Ehrenberg, 1840, p. 207; Ehrenberg, 1854, pl. 18, figs. 56; pl. 33 (XV), fig. 9 , 
Remarks. Specimens counted as Distephanus crux crux may include cruxoid variants of other species. A bridged specimen is included in the counts for Sample 138-844B-15H-4, 120-121 cm.

\section{Distephanus longispinus (Schulz) Bukry and Foster}

Distephanus crux f. longispinus Schulz, 1928, p. 256, fig. 44

Distephanus longispinus (Schulz), Bukry and Foster, 1973, p. 828, pl. 4, figs. 7.8.

\section{Distephanus polyactis (Ehrenberg)}

$$
\text { (Pl. 6, Fig. 7) }
$$

Dictyocha polyactis Ehrenberg, 1840, p. 129.

Distephanus polyactis (Ehrenberg), Bukry, 1979a, p. 562, pl. 3; figs. 15, 16; pl. 4 , fig. I.

Remarks. One specimen found in Sample 138-844B-6H-4, 120-121 cm.

\section{Distephanus pulchra (Schiller) Ling and Takahashi}

Octactis pulchra Schiller, 1925, p. 67-68, fig. c.

Distephanus pulchra (Schiller), Ling and Takahashi, 1985, p. 80, pls. 1-2.

Remarks. The eight-sided D. pulchra is especially common in coastal waters (see Schrader et al., 1986). This taxon was consistently found throughout the Pleistocene section of Hole 847B; it was scattered at other Leg 138 sites. A single specimen was found in Sample 138-844B-2H-2, 120-121 cm.

Distephanus quinquangellus Bukry and Foster (Pl. 8, Fig. 3; Pl. 10, Fig. 3)

Distephanus quinquangellus Bukry and Foster, 1973, p. 828, pl. 5, fig 4.

Remarks. This taxon has been used for five-sided distephanid morphologies that are larger than the co-occurring Distephanus speculum. The type specimen is from DSDP Site 157, where it often represented several percent of the total silicoflagellate counts from the Pleistocene and Pliocene sections; Distephanus quinquangellus specimens in this study were noticeably less abundant than those at Site 157.

A specimen having two apical windows was found in Sample 138-850B$18 \mathrm{H}-1,120-121 \mathrm{~cm}$.

\section{Distephanus speculum giganteus Bukry} (PI. 6, Fig. 4)

Distephanus speculum giganteus n. subsp. Bukry, 1976b, p.848, pl. 1, fig. 19; pl. 2 , figs. 1,2 .

Distephanus speculum giganteus Bukry, Bukry, 1981a, p. 550, pl. 4, figs. 1. 2.

Remarks: This taxon has a large basal ring that is hexagonal in shape, and a distinctly longer pair of major axis spines. The sides may be straight or slightly convex. Basal pikes are offset from the junctions of the struts and are small and blunt. The apical ring is rounded and only slightly smaller than the basal ring. It is distinguished from $D$. speculum speculum by its large size and large apical ring, and from $D$. boliviensis boliviensis by the disparity in axial spine length as well as by the large apical ring.

\section{Distephanus speculum hemisphaericus (Ehrenberg) Bukry}

(Pl. 6. Figs. 2, 5, 8; Pl. 7, Fig. 6)

Dictyocha hemisphaerica Ehrenberg, 1844, pl. 17, fig. 5.

Distephanus speculum hemisphaericus (Ehrenberg), Bukry, 1975c, p. 854.

Remarks. This taxonomy is used to describe those speculum-type morphologies displaying multiple apical windows, except for those specimens contained within the lectotype of $D$. boliviensis boliviensis.

\section{Distephanus speculum minutus (Bachmann) Bukry}

\section{(PI. 7, Fig. 3)}

Dictyocha speculum f. minuta Bachmann in Ichikawa, et al., 1967, p. 161, pl. 7. figs. $12-15$,

Distephanus minutus (Bachmann), Bukry and Foster, 1973, p. 828, pl. 4, figs. 10.11.

Distephanus speculum minutus (Bachmann), Bukry, 1976a, p. 895, pl. 8, figs. 1-3.

\section{Distephanus speculum patulus Bukry}

Distephanus speculum patulus Bukry, 1982b, p. 433, pl. 5, figs. 7-10.

Remarks. Found in Sample 138-844B-29H-4, 120-121 cm. D. speculum patulus is moderately sized with semi-equant spines and a small to moderately sized apical ring.

Distephanus speculum pentagonus Lemmermann

$$
\text { (PI. 7, Fig. 4) }
$$

Distephanus speculum var. pentagona Lemmermann, 1901, p. 264, pl. 11, fig. 19.

Distephanus speculum pentagonus Lemmermann, Bukry, 1976a, p. 895-896: McCartney and Wise, 1990, pl. 3, figs. 3-6.

Remarks. Although similar in appearance to Distephanus quinquangellus having a five-sided basal structure with five semi-equant spines, this group is distinguished by its smaller size, which compares with that of $D$. speculum speculum. The counts include one specimen from Sample 138-844B-15H-4. $120-121 \mathrm{~cm}$, that was similar to that illustrated by McCartney and Wise (1987. pl. 2, fig. 9).

Distephanus speculum speculum f. pseudofibula Schulz

Distephanus speculum f. pseudofibula Schulz, 1928, p. 262, figs. 5Ia, 5 Ib. Distephanus speculum speculum f. pseudofibula Schulz, Locker and Martini, 1986b, p. 907 . pl. 7, fig. 5.

Remarks. One specimen was found in Sample 138-844B-12H-2, 120-12I $\mathrm{cm}$

\section{Distephanus speculum speculum (Ehrenberg) Bukry and Foster}

$$
\text { (Pl. 3, Fig. 3; Pl. 4, Fig. 7; Pl. 10, Fig. 7) }
$$

Dictyocha speculum Ehrenberg, 1840; Ehrenberg, 1854, pl. 18, fig. 57; pl. 19, fig. 41 , pl. 21 , fig. 44 ; pl. 22 , fig. 47.

Distephanus speculum (Ehrenberg) Haeckel, I887, p. 1565.

Distephanus speculum speculum (Ehrenberg), Bukry and Foster, 1973, p. 828, pl. 5 , fig. 8 .

Remarks. Specimens from the Pliocene section of Site 848 often were of small size. Considerable variation exists in the lengths of the basal spines, with some having short spines while others have spines longer than the diameter of the basal ring. Five-, seven- and eight-sided and multiwindowed variants are listed separately in the range charts, but have not been formally defined as separate forms: these morphologies are consistently uncommon. An unusual five-sided specimen (see McCartney and Wise, 1987, pl. 2, fig. 9) was found in Sample 138-851B-24X-1, 120-121 cm. Rare examples of the pseudofibulid morphologies (McCartney and Wise, 1990) also were found and are tabulated separately in the abundance charts.

Distephanus speculum temuis Bukry

(PI. 1. Figs. 9, 10; Pl. 5, Fig. 1; PI. 10, Fig. 6)

Distephanus speculum tenuis Bukry, 1982b, p 316, pl. 6, figs. 5-11.

Remarks. This unusual silicoflagellate has an apical structure made up of very thin skeletal elements; in many cases, the skeleton lacks an apical structure entirely, but whether this is a primary feature or the result of breakage is uncertain. This taxon appears to be abundant in the late Miocene section only at sites very near the equator. These include Sites 503 (Bukry, 1982b), 849. 850,851 and 847 ; all of these are within $5^{\circ}$ of the equator. Sites farther away from the equator do not have this distinctive morphology. The absence of this morphology at Site 844 (latitude $9^{\circ} \mathrm{N}$ ) or at Site 495 (latitude $12^{\circ} \mathrm{N}$ ) shows that these morphologies have been restricted to near-equatorial waters and that they were not transported by surface waters for great distances away from the equator.

The apical structure of Distephanus speculum tenuis is similar to that of $D$. pulchra, which is from the Pleistocene and Holocene. D. pulchra is found typically in coastal regions and generally is uncommon in the open ocean (Poelchau, 1974). Schrader et al. (1986) thought that this taxon was indicative of long, persistent upwelling seasons. It is uncertain whether this information can be applied readily to the similar D. speculum tenuis, but its occurrence on the equator during the late Miocene may be indicative of especially persistent upwelling conditions. 
A single seven-sided specimen of this taxon was found in $-851 \mathrm{~B}-18 \mathrm{H}-1$, $120-121 \mathrm{~cm}$, and was included within the general counts for that sample.

$$
\text { Distephanus pulchra (Schiller) Ling and Takahashi }
$$$$
\text { (Pl. 10, Fig. 6) }
$$

Octactis pulchra Schiller, 1925, p. 67-68, fig. c.

Distephanus pulchra (Schiller), Ling and Takahashi, 1985, p. 80, pls. 1-2.

Remarks. This species is an eight-sided form of Distephanus and has an extremely delicate apical structure. With the exception of the number of sides it is similar to Distephanus speculum tenuis, although these species have markedly different geologic ranges and are probably independent of one another in development. The apical structure of this species often was broken or missing. It was present in the Pleistocene and upper Pliocene sediments in Hole 849B, but was not observed at all in Hole 852B.

$$
\text { Distephanus stauracanthus f. stauracanthus (Ehrenberg) Haeckel }
$$$$
\text { (PI. 6, Fig, 6) }
$$

Distephanus stauracanthus (Ehrenberg) Haeckel, 1887, v. 18, p. 1564.

Distephamus stauracanthus (Ehrenberg) Haeckel, Locker and Martini, 1986b, p. 907.

Distephamus stauracathus f. octagonus (Tsumara) Locker and Martini

$$
\text { (PI. 6, Fig. 9) }
$$

Dictyocha fibula var. octagona Tsumara, 1963, pl. 2, fig. 4; pl. 10, figs. 11-13.: pl. 23, figs. 8-10.

Dictyocha octagona (Tsumara), Martini. 1971. p. 1697, pl 1., fig. 15.

Distephanus stauracanthus f. octagonus (Tsumara), Locker and Martini, 1986b, p. 907 , pl. 6, fig. 8.

Remarks. This taxon is distinguished by its eight-sided basal ring, which displays eight equant spines. It differs from D. stauracanthus stauracanthus in having an inclined dictyochid bridge, rather than a cruxoid apical ring.

\section{Distephanus xenus Bukry}

(Pl. 10, Figs. 4, 5)

Distephanus xenus Bukry, 1984. p. 557. pl. I, figs. 11, 12; PI. 2, figs. I-8.

Remarks. This species has a large hexagonal-shaped basal ring with a large apical ring. The basal ring either lacks spines or has only rudimentary spines. It has the overall skeletal appearance of $D$. boliviensis without basal spines.

\section{Genus NEONAVICULOPSIS Locker and Martini. 1986}

Neonaviculopsis neonautica neonautica (Bukry) Locker and Martini

Dictyocha navicula Ehrenberg, Bukry and Foster, 1973 (in part). p. 827, pl. 3 , figs. 6, 7.

Dictyocha neonautica Bukry 1981b, p. 442.

Dictyocha neonautica neonautica Bukry, 1981a, p. 549, pl. 3, fig. 4.

Dictyocha neonautica Bukry, 1982b (in part), p. 316, pl. 2, fig. 10.

Neonaviculopsis neonautica Locker and Martini. 1986b, p. 909, pl. 10, figs. 6-11.

Remarks. Neonaviculopsis neonautica here is restricted to skeletal morphologies that are larger and more elongate than Bachmannocena diodon nodosa. The range of variation of $B$. diodon nodosa includes naviculopsid skeletons, but because we view these as the result of variation within the species, we are thus reluctant to place these within the separate genus Neonaviculopsis. The Neonaviculopsis morphologies generally occur within and immediately above the $B$. diodon nodos $a$ Horizon, although they also occur just below the horizon in Sample 138-850B-17X-1. 120-121 cm.

\section{Neonaviculopsis neonautica praenautica Locker and Martini}

$$
\text { (Pl. I. Fig. 7) }
$$

Neonaviculopsis neonautica praenautica Locker and Martini, 1986b. p. 909 , pl. 10, figs. $1-5,12$.

Remarks. This skeletal morphology has the appearance of a Dictyocha. with a bridge parallel to the minor axis but without minor-axis spines. While members of this taxon are closely related to Neonaviculopsis neonautica neonautica, the general morphology is polyphyletic because very similar skeletons can occur within the range of variation of various Dictyocha and Naviculopsis taxa (see Perch-Nielsen, 1976; Bukry, 1976b). Praenauticid variants of Dictyocha fibula ausonia occur in Samples 138-850B-21 H-1, 120-121 $\mathrm{cm}$ (Pl. 2, Figs. 3, 4).

\section{Ebridians}

Only Holes $844 \mathrm{~B}, 848 \mathrm{~B}, 850 \mathrm{~B}$ and $85 \mathrm{IB}$ were examined for ebridians. The absence of ebridians on the charts for the other sites does not necessarily mean that ebridians were not found to occur there.

\section{Genus AMMONOCHIUM Hovasse, 1932}

Ammonochium serotinum Locker and Martini

Ammonochium serotinum Locker and Martini, 1986a, p. 943, pl. 2, figs. 1,2.

Remarks. Specimens were found scattered in the middle Miocene section of Hole 844B and a single specimen was found in Sample 138-844B-14H-4, $120-121 \mathrm{~cm}$.

Genus EBRIOPSIS Hovasse, 1932

Ebriopsis antiqua antiqua (Schulz) Ling

Ebria antiqua Schulz, 1928 (in part), pp. 273, 274, fig. 696.

Ebriopsis antiqua antiqua (Schulz), Ling, 1977, p. 215, pls. 17, 18.

Remarks. Single specimens of this taxon were found in Samples 138850 B-5H-1. 120-121 cm, and Sample 138-850B-12X-1, 120-121 cm.

\section{Genus HERMESINUM Zacharias, 1906}

Hermesinum adriaticum Zacharias

Hermesinum adriaticum Zacharias, 1906, p. 394, figs. a-d.

Remarks. This taxon was scattered in the upper Miocene and lower Pliocene sediments of Holes 844B, 850B and -851B.

\section{Genus PARATHRANIUM Hovasse, 1932}

Parathranium tenuipes (Hovasse), Ling

Thranium tenuipes Hovasse, 1932, p. 123, fig. 5.

Parathranium tenuipes (Hovasse), Ling, 1972, pp. 198-199.

Remarks. Specimens of this ebridian were scattered in the Miocene and Pliocene sediments of Hole 850B and in Sample 138-85।B-12H-1, 34-35 cm. This species differs from the earlier $P$. intermedium in having relatively thinner skeletal elements (Ling and McPherson, 1974; Perch-Nielsen, 1975).

\section{ACKNOWLEDGMENTS}

We would like to acknowledge William Duncan, with assistance from Cynthia MacNeil and Virginia Coleman, for able work in doing the photography for this paper. Technical assistance was provided by Sherry Churchill and Linda Woestendiek. Comments by Sigurd Locker, Hsin Yi Ling, and Sherwood Wise were helpful for improving the quality of this paper. Support was provided by USAAC funds and an equipment grant from NSF Grant No. OCE-9113073. This is Publication No. 4 of the Micropaleontology Undergraduate Research Laboratory.

\section{REFERENCES}

Bukry, D., 1973. Coccolith and silicoflagellate stratigraphy, Tasman Sea and southwestern Pacific Ocean, Deep Sea Drilling Project Leg 21. In Burns, R.E., Andrews, J.E., et al., Init. Repts. DSDP, 21: Washington (U.S. Govt. Printing Office), 885-893.

.1975a. Coccolith and silicoflagellate stratigraphy, northwestern Pacific Ocean, Deep Sea Drilling Project Leg 32. In Larson, R.L., Moberly, 
R., et al., Init. Repts. DSDP, 32: Washington (U.S. Govt. Printing Office), $677-701$.

1975b. Phytoplankton stratigraphy, southwest Pacific, Deep Sea Drilling Project, Leg 30. In Andrews, J.E., Packham, G., et al., Init. Repts. DSDP, 30: Washington (U.S. Govt. Printing Office), 539-547.

.1975c. Silicoflagellate and coccolith stratigraphy, Deep Sea Drilling Project, Leg 29, In Kennett, J.P.. Houtz, R.E., et al., Init. Repts. DSDP, 29: Washington (U.S. Govt. Printing Office), 845-872.

, 1976a. Cenozoic silicoflagellate and coccolith stratigraphy, South Atlantic Ocean, Deep Sea Drilling Project Leg 36. In Hollister, C.D., Craddock, C., et al., Init. Repts. DSDP, 35: Washington (U.S. Govt. Printing Office), 885-917.

1976b. Silicoflagellate and coccolith stratigraphy, NorwegianGreenland Sea, Deep Sea Drilling Project Leg 38. In Talwani, M., Udintsev, G., et al., Init. Repts. DSDP, 38: Washington (U.S. Govt. Printing Office), 843-855.

1976c. Silicoflagellate and coccolith stratigraphy, southeastern Pacific Ocean, Deep Sea Drilling Project Leg 34. In Yeats, R.S., Hart, S.R. et al., Init. Repts. DSDP, 34: Washington (U.S. Govt. Printing Office), $715-735$.

1977. Coccolith and silicoflagellate stratigraphy, central north Atlantic Ocean, Deep Sea Drilling Project Leg 37. In Aumento, F., Melson, W.G., et al., Init. Repts. DSDP, 37: Washington (U.S. Govt. Printing Office), $917-927$.

1978a. Cenozoic coccolith and silicoflagellate stratigraphy, offshore northwest Africa, Deep Sea Drilling Project Leg 4I. In Lancelot, Y. Seibold, E., et al., Init. Repts. DSDP. 41: Washington (U.S. Govt. Printing Office), $689-707$.

1978b. Cenozoic coccolith, silicoflagellate, and diatom stratigraphy, Deep Sea Drilling Project Leg 44. In Bensen, W.E., Sheridan, R.E., et al.. Init. Repts. DSDP, 44: Washington (U.S. Govt. Printing Office), 807863.

1978c. Cenozoic silicoflagellate and coccolith stratigraphy, south eastern Atlantic Ocean, Deep Sea Drilling Project Leg 40. In Bolli, H.M. Ryan, W.B.F., et al., Init. Repts. DSDP, 40: Washington (U.S. Govt. Printing Office), 635-649.

1979a. Coccolith and silicoflagellate stratigraphy, northern MidAtlantic Ridge and Reykjanes Ridge, Deep Sea Drilling Project Leg 49. In Luyendyk, B.P., Cann, J.R., et al., Init. Repts. DSDP, 49: Washington (U.S. Govt. Printing Office), 551-581.

1979b. Comments on opal phytoliths and stratigraphy of Neogene silicoflagellates and coccoliths at Deep Sea Drilling Project Site 397 off northwest Africa. In Luyendyk, B.P., Cann, J.R., et al., Init. Repts. DSDP. 49: Washington (U.S. Govt. Printing Office), 977-1009.

1980a. Miocene Corbisema triacantha Zone phytoplankton from Deep Sea Drilling Project Sites 415 and 416, off Northwest Africa. In Lancelot, Y.. Winterer, E.L., et al., Init. Repts. DSDP. 50: Washington (U.S. Govt. Printing Office), 507-523.

1980b. Silicoflagellate biostratigraphy and paleoecology in the eastern equatorial Pacific, Deep Sea Drilling Project Leg 54. In Rosendahl, B.R., Hekinian, R., et. al., Init. Repts. DSDP, 54: Washington (U.S. Govt. Printing Office), 545-573.

1981a. Silicoflagellate stratigraphy of offshore California and Baja California, Deep Sea Drilling Project Leg 63. In Yeats, R.S., Haq, B.U., et al., Init. Repts. DSDP, 63: Washington (U.S. Govt. Printing Office), 539557.

1981b. Synthesis of silicoflagellate stratigraphy for Maastrichtia to Quaternary marine sediments. In Warme, T.E., Douglas, R.C., and Winterer, E.L. (Eds.), The Deep Sea Drilling Project: a Decade of Progress. Spec. Publ._Soc. Econ. Paleontol. Mineral., 32:433-444.

1982a. Cenozoic silicoflagellates from offshore Guatemala, Deep Sea Drilling Project Site 495. In Aubouin, J., von Huene, R., et al., Init. Repts. DSDP, 67: Washington (U.S. Govt. Printing Office), 425-445.

1982b. Neogene silicoflagellates of the eastern equatorial Pacific Deep Sea Drilling Project Hole 503A. In Prell, W.L., Gardner, J.V., et al. Init. Repts. DSDP, 68: Washington (U.S. Govt. Printing Office), 311-323.

1983. Upper Cenozoic silicoflagellates from offshore Ecuador. Deep Sea Drilling Project Site 504. In Cann, J.R., Langseth, M.G.. Hon-

\footnotetext{
"Abbreviations for names of organizations and publications in ODP reference lists follow the style given in Chemical Abstracts Service Source Index (published by American Chemical Society).
}

norez, J., Von Herzen, R.P., White, S.M., et al., Init. Repts. DSDP, 69: Washington (U.S. Govt. Printing Office), 321-342.

, 1984. Neogene silicoflagellates from Deep Sea Drilling Project Site 543, western tropical Atlantic Ocean. In Biju-Duval, B., Moore, J.C., et al., Init. Repts. DSDP, 78A: Washington (U.S. Govt. Printing Office), 463468.

1985. Tropical Pacific silicoflagellate zonation and paleotemperature trends of the late Cenozoic. In Mayer, L., Theyer, F., Thomas, E., et al.. Init. Repts. DSDP, 85: Washington (U.S. Govt. Printing Office), $477-$ 497.

1987. Eocene siliceous and calcareous phytoplankton, Deep Sea Drilling Project Leg 95. In Poag, C.W., Watts, A.B., et al., Init. Repts. DSDP, 95: Washington (U.S. Govt. Printing Office), 395-415.

Bukry, D., and Foster, J.H.. 1973. Silicoflagellate and diatom stratigraphy, Leg 16, Deep Sea Drilling Project. In van Andel, T.H., Heath, G.R., et al., Init. Repts. DSDP, 16: Washington (U.S. Govt. Printing Office), 815-871.

Burckle, L.H., 1981. Paleomagnetic data on the Dictyocha asperalfibula crossover at the equatorial Pacific. Micropaleontology, 27:332-334.

Deflandre, G., 1950. Contribution a l'étude des silicoflagellidés actuels et fossiles. Microscopie, 2:72-108, 117-142, 191-210.

Dumitrica, P., 1973. Paleocene, late Oligocene and post-Oligocene silicoflagellates in southwestern Pacific sediments cored on DSDP Leg 21. In Burns, R.E., Andrews, J.E., et al., Init. Repts. DSDP, 21: Washington (U.S. Govt. Printing Office), 837-883.

Ehrenberg, C.G., 1840. 274 Blatter von ihm selbst augefuhrter Zeichnungen von ebenso vielen Arten. K. Preuss. Akad. Wiss. Berlin Ber., 1840:197219.

1843. Verbreitung und Einfluss des mikroskopischen Lebens in Süd- und Nord-Amerika. Abh. Preuss. Akad. Wiss. Berlin Physik.-Math. Kl., 4:291-446.

1844. Mittheilung uber zwei neue Lager von Gebirgsmassen aus Infusonien als Meeres-Absatz in Nord-Amerika und eine Vergleichung derselben mit den organischen Kreide-Gebilden in Europa und Afrika. $K$. Preuss Akad. Wiss. Berlin, Berichte, 1844, 57-97.

1854. Mikrogeologie: Das Erden und Felsen schaffende Wirken des unsichtbar kleines selbständigen Lebens auf der Erde: Leipzig (Leopold Voss).

Frenguelli, J., 1940. Consideraciones sobre los silicoflagelados fósiles. Rev. Mus. La Plata, Secc. Geol., 2:37-112.

1951. Silicoflagelados del Trípoli de Majillones (Chile). Physis, 20:272-284

Gemeindhardt, K., 1930. Silicoflagellatae. In Rabenhorst, L., KryptogamenFlora von Deutschland, Osterreich und der Schweiz. Leipzig Akad. Verlagsgesell., 10:1-87.

Haeckel, E., 1887. Report on the Radiolaria collected by H.M.S. Challenger during the years 1873-1876. Rep. Sci. Results Voy. H.M.S. Challenger, 1873-1876, Zool., 18:1-1803.

Hovasse, R., 1932. Note preliminaire sur les ébriacées. Bull. Soc. Zool. Fr. 57:118-131.

Ichikawa, W., Shimizu, I., and Bachmann, A., 1967. Fossil silicoflagellates and their associated uncertain forms in lida Diatomite, Noto Peninsula, Central Japan. Sci. Rep. Kanazawa Univ., 12:143-172.

Lemmermann, E., 1901. Silicoflagellatae. Ber. Dtsch. Bot. Ges., 19:247-271.

Ling, H.Y., 1972. Upper Cretaceous and Cenozoic silicoflagellates and ebridians. Bull Am. Paleontol., 62:135-229.

1975. Silicoflagellates and ebridians from Leg 31. In Karig, D.E., Ingle, J.C., Jr., et al., Init. Repts. DSDP, 31: Washington (U.S. Govt. Printing Office), 763-777.

1977. Late Cenozoic silicoflagellates and ebridians from the eastern North Pacific region. In Saito, T., and Ujiie, H. (Eds.), Proc. First Int. Congr. Pacific Neogene Stratigraphy, Tokyo 1976, 205-233.

Ling, H.Y., and McPherson, L.M., 1974. Study on the ebridian genus Parathranitum Hovasse. Rev. Espan. Micropaleontol., 6:191-200.

Ling, H.Y., and Takahashi, K., 1985. The silicoflagellate genus Octactis Schiller 1925: a synonym of the genus Distephanus. Micropaleontology, 31:76-81.

Locker, S., 1974. Revision der Silicoflagellaten aus der Mikrogeologischen Sammlung von C.G. Ehrenberg. Ecologae Geol. Helv., 67:631-646.

1975. Dictyocha varia sp. n., eine miozäne Silicoflagellaten-Art mit kompliziertem Variationsmodus. Akad. Geol. Wiss., 3:99-103.

Locker, S.. and Martini, E., 1986a. Ebridians and actiniscidians from the southwest Pacific. In Kennett, J.P., von der Borch, C.C., et al., Init. Repts. DSDP. 90: Washington (U.S. Govt. Printing Office), 939-95!. 
, 1986b. Silicoflagellates and some sponge spicules from the southwest Pacific, DSDP 90. In Kennett, J.P., von der Borch, C.C., et al., Init. Repts. DSDP. 90: Washington (U.S. Govt. Printing Office), 887-924.

Loeblich. A., III. Loeblich, L.A., Tappan, H., and Loeblich, A.R., Jr., 1968. Annotated index of fossil and recent silicoflagellates and ebridians with descriptions and illustrations of validly proposed taxa. Mem.-Geol. Soc. Am., 106:1-319.

Martini, E., 1971. Neogene silicoflagellates from the equatorial Pacific. In Winterer, E.L., Riedel, W.R., et al., Init. Repts. DSDP. 7 (Pt. 2): Washington (U.S. Govt. Printing Office), 1695-1708.

1972. Der stratigraphische Wert von Silicoflagellaten im Jungertiär von Kalifornien und des östlichen Pazifischen Ozeans. Nachr. D. Geol. Ges., 5:47-49.

, 1976. Neogene and Quaternary silicoflagellates from the Central Pacific Ocean (DSDP Leg 33). In Schlanger, S.O.. Jackson, E.D., et al.. Init. Repts. DSDP, 33: Washington (U.S. Govt. Printing Office), 439-449.

, 1990. Tertiary and Quaternary silicoflagellates, actiniscidians, and ebridians from the eastern Pacific off Peru (Leg 112). In Suess, E., von Huene, R., et al., Proc. ODP, Sci. Results, 112: College Station, TX (Ocean Drilling Program), 157-173.

Martini, E., and Müller, C., 1976. Eocene to Pleistocene silicoflagellates from the Norwegian-Greenland Sea (DSDP Leg 38). In Talwani, M., Udintsev, G., et al., Init. Repts. DSDP. 38: Washington (U.S. Govt. Printing Office). $857-895$.

McCartney, K., and Harwood, D.M., 1992. Silicoflagellates from Leg 120 on the Kerguelen Plateau, southeast Indian Ocean. In Wise, S.W., Jr., Schlich, R., et al., Proc. ODP. Sci. Results, 120: College Station, TX (Ocean Drilling Program), 811-831.

McCartney, K., and Loper, D.E., 1989. Optimized skeletal morphologies of silicoflagellate genera Dictyocha and Distephanus. Paleobiology, 15:283298.

McCartney, K., and Wise, S.W., Jr., 1987. Silicoflagellates and ebridians from the New Jersey Transect, Deep Sea Drilling Project Leg 93, Sites 604 and 605. In van Hinte, J.E., Wise, S.W., Jr., et al., Init. Repts. DSDP, 93 (Pt. 2): Washington (U.S. Govt. Printing Office), 801-814.

1990. Cenozoic silicoflagellates and ebridians from ODP Leg 113 : biostratigraphy and notes on morphologic variability. In Barker, P.F.,
Kennett, J.P., et al., Proc, ODP, Sci. Results, 113: College Station, TX (Ocean Drilling Program), 729-760.

Perch-Nielsen, K., 1975. Late Cretaceous to Pleistocene archaeomonads, ebridians, endoskeletal dinoflagellates, and other siliceous microfossils from the subantarctic southwest Pacific, DSDP, Leg 29. In Kennett, J.P. Houtz, R.E., et al., Init. Repts. DSDP, 29: Washington (U.S. Govt. Printing Office), 873-907.

1976. Eocene to Pliocene archaeomonads, ebridians, and endoskeletal dinoflagellates from the Norwegian Sea, DSDP Leg 38. In Talwani, M., Udintsev, G., et al., Init. Repts. DSDP, 38 (Suppl.): Washington (U.S. Govt. Printing Office), 147-175.

Peters, W., 1860. Kurzen Auszug aus einer Abhandlung des Hrn. Dr. Ernst Haeckel über neue, ledende Radiolarien des Mittelmeeres und legte die dazu gehörigen Abbildungen vor. Mber. Verh. K. Preuss. Akad. Wiss. Berlin, $794-817$.

Poelchau, H.S., 1974. Holocene silicoflagellates of the North Pacific: their distribution and use for paleotemperature determination [Ph.D. dissert.]. Univ. of California, San Diego.

-1976. Distribution of Holocene silicoflagellates in North Pacific sediments. Micropaleontology, 22:164-193.

Schiller, J., 1925. Die planktontischen Vegetation des adriatischen Meers: B. Chrysomonadina, Heterokontae, Cryptomonadina, Eugleninae, Volvocales. 1. Systematischer Teil. Arch. Protistenkd., 53:59-123.

Schrader, H., Pisias, N., and Cheng, G., 1986. Seasonal variation of silicoflagellates in phytoplankton and varved sediments in the Gulf of California. Mar. Micropaleontol., 10:207-233.

Schulz, P., 1928. Beiträge zur Kenntnis fossiler und rezenter Silicoflagellaten. Bot. Arch., 21:225-292.

Tsumara, K., 1963. A systematic study of silicoflagellatae. J. Yokohama Mun. Univ., C-45, 146:1-84.

Zacharias, O., 1906. Eine neue Dictyochide aus dem Mittelmeer, Hermesinum adriaticum n. g., n. sp. Arch. Hydrobiol. u. Planktonk., 1:394-398.

Date of initial receipt: 23 February 1993

Date of acceptance: 18 November 1993

Ms 138SR-108 


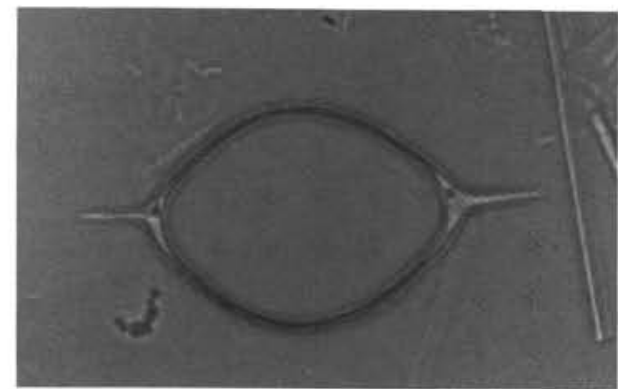

1

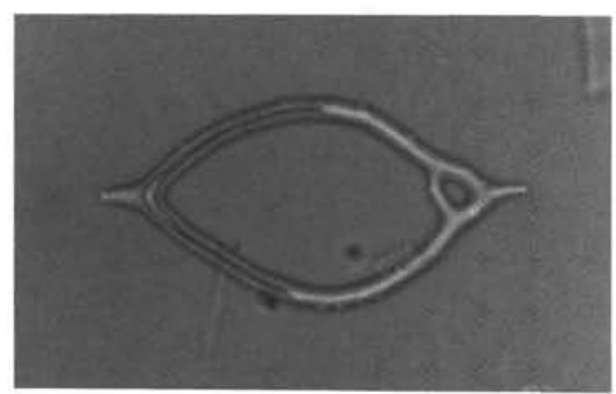

2

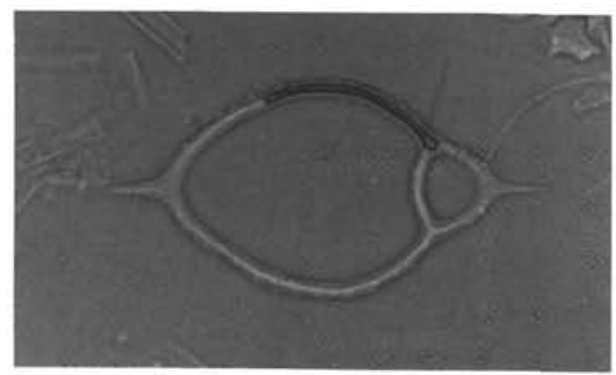

3

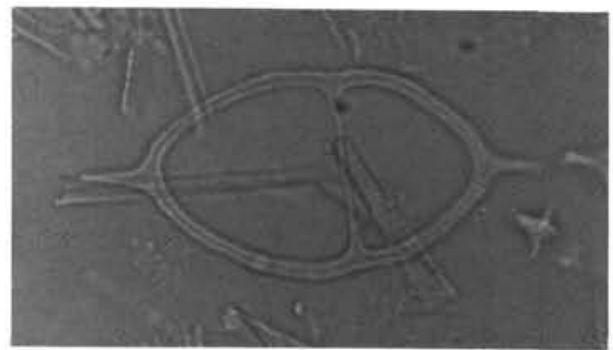

4

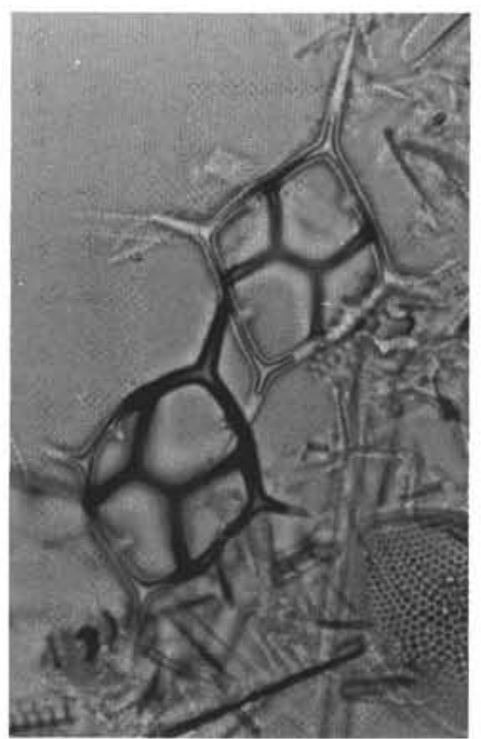

5

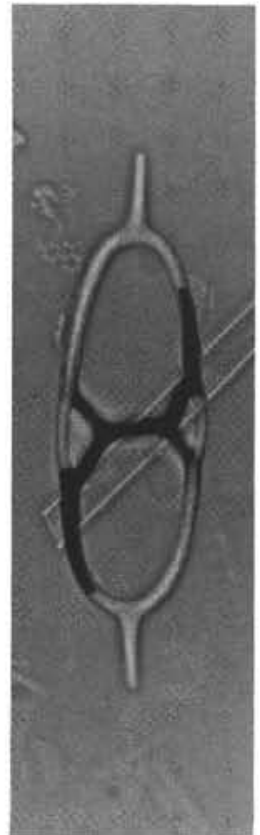

7

9

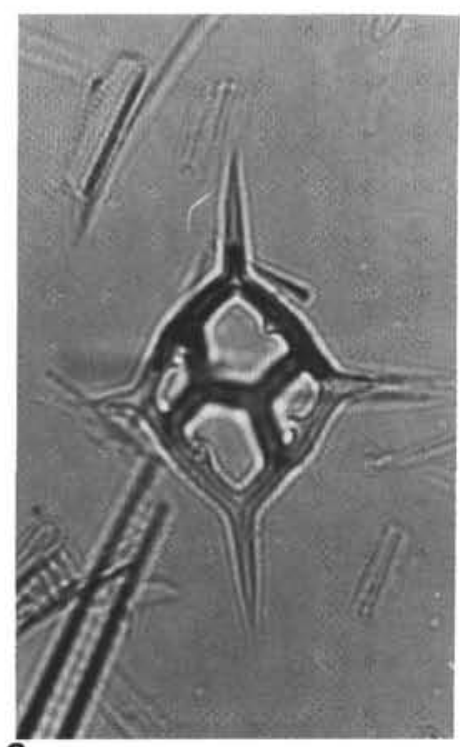

6
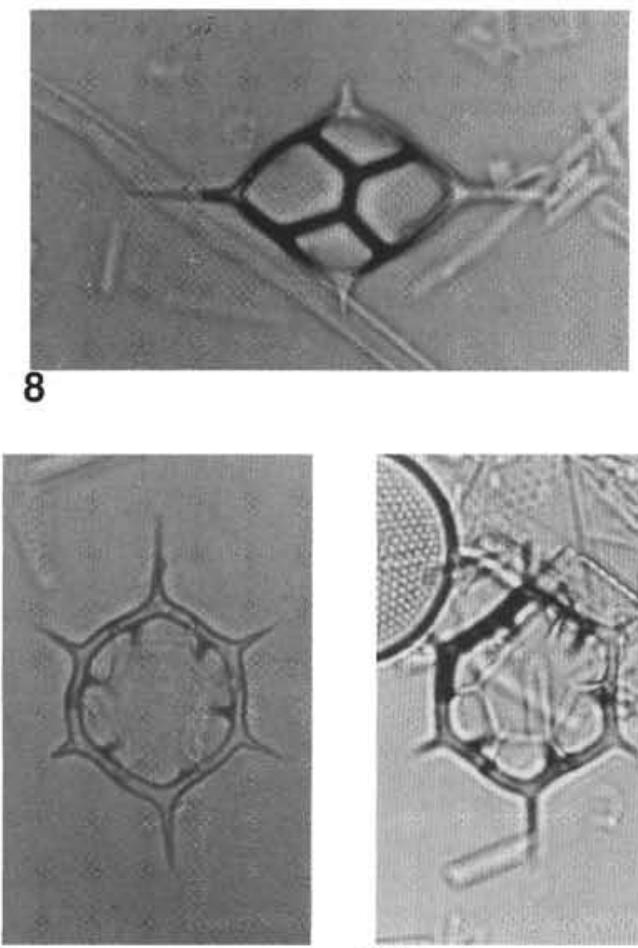

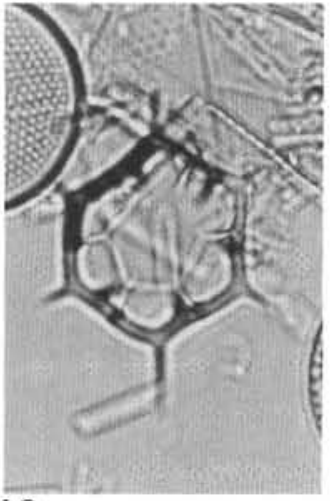

10

Plate 1. Silicoflagellates from Sites 848,850 , and 851 (magnification $850 \times$ ). 1. Bachmannocena diodon nodosa (Bukry), Sample 138-848B-7H-4, 120-121 $\mathrm{cm}$. 2, 3. Bachmannocena diodon nodosa f. transenna (Bukry), Sample 138-848B-7H-4, 120-121 cm. 4. Bachmannocena diodon nodosa f. cocoensis (Bukry), Sample 138-848B-7H-4, 120-121 cm. 5, 6. Dictyocha subclinata Bukry, Sample 138-850B-33X-1, 120-121 cm. 7. Neonaviculopsis neonautica praenautica Locker and Martini, Sample 138-850B-16H-1, 120-121 cm. 8. Dictyocha subclinata Bukry, Sample 138-850B-33X-1, 120-121 cm. 9, 10. Distephanus speculum tenuis Bukry; (9) Sample 138-850B-21X-1, 120-121 cm; (10) Sample 138-850B-19X-1, 120-121 cm. 


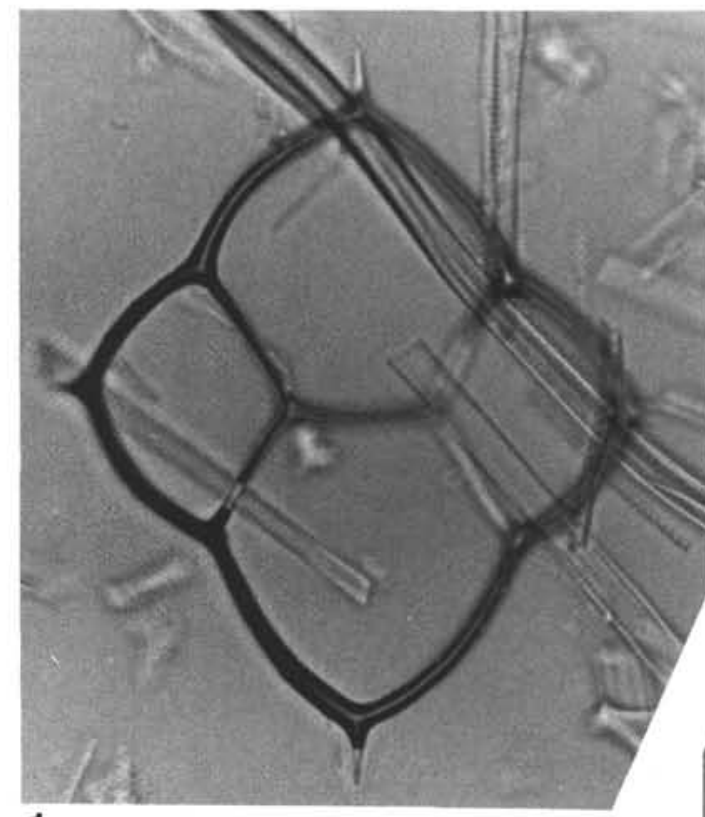

1

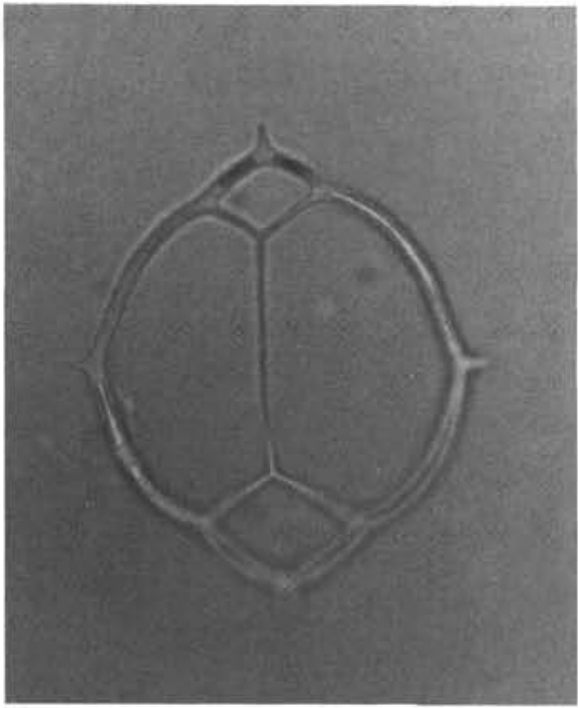

5

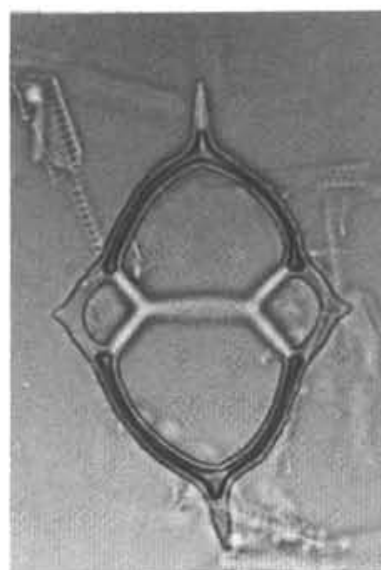

2

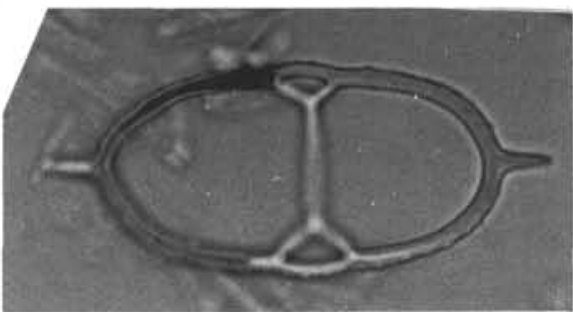

4

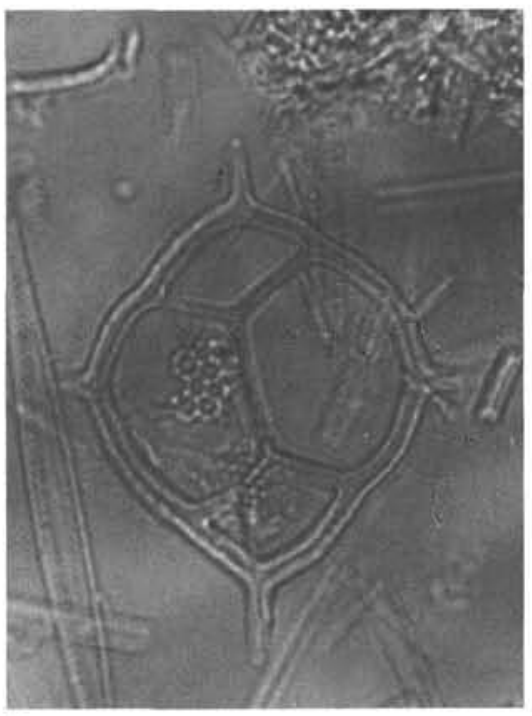

6

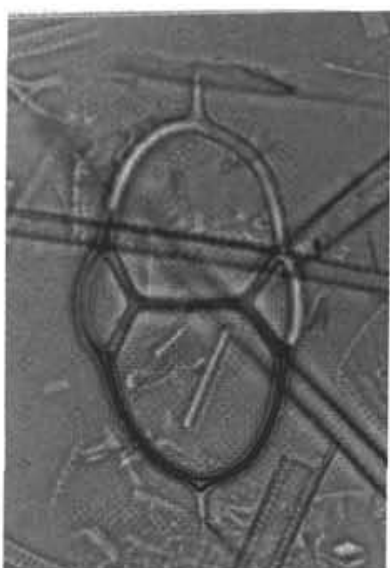

3

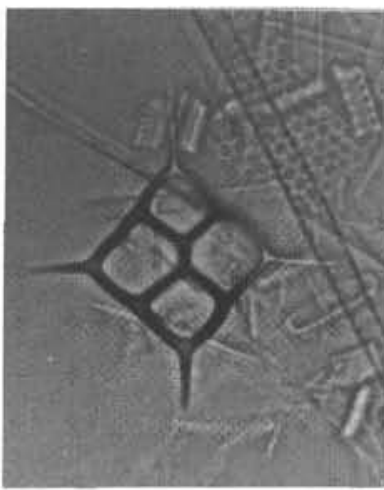

7

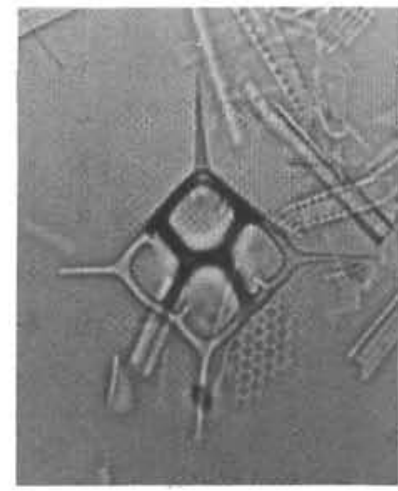

8

Plate 2. Silicoflagellates from Sites 848,850 , and 851 (magnification $850 \times$ ). 1. Dictyocha fibula fibula Ehrenberg, Sample 138-850B-25X-1, 120-121 cm. 2. Dictyocha fibula ausonia (Deflandre), Sample 138-850B-21X-1,120-121 cm. 3,4. Dictyocha fibula ausonia (Deflandre) (praenauticid), Sample 138-850B$21 \mathrm{X}-1,120-121 \mathrm{~cm}$. 5. Distephanus crux carolae Bukry (bridged), Sample 138-850B-16X-1, 120-121 cm. 6. Dictyocha delicata bisecta (Bukry), Sample 138-848B-6H-4, 120-121 cm. 7. Dictyocha perlaevis flexatella Bukry, Sample 138-851B-6H-1, 120-121 cm. 8. Distephanus crux carolae Bukry (bridged), Sample 138-850B-16X-1, 120-121 cm. 


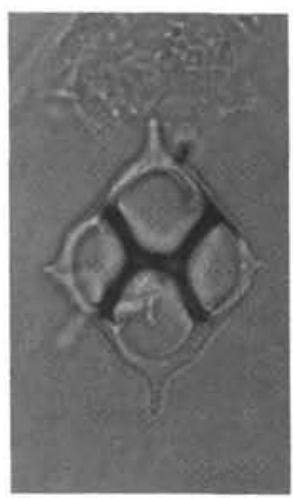

1

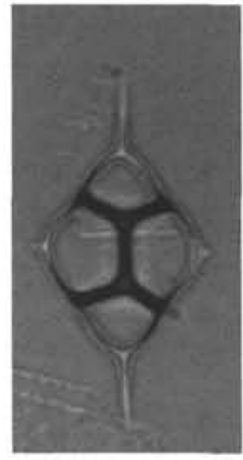

6

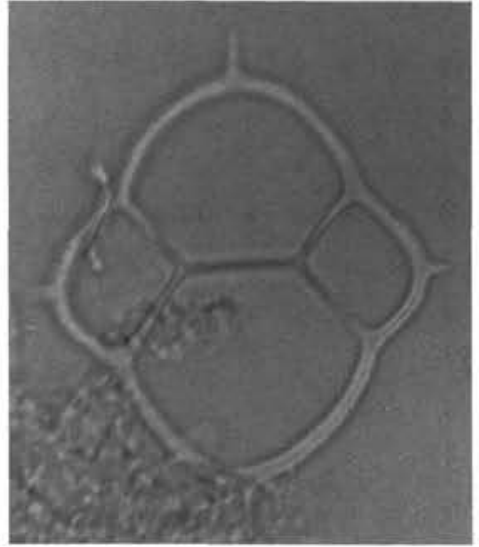

11

2

7
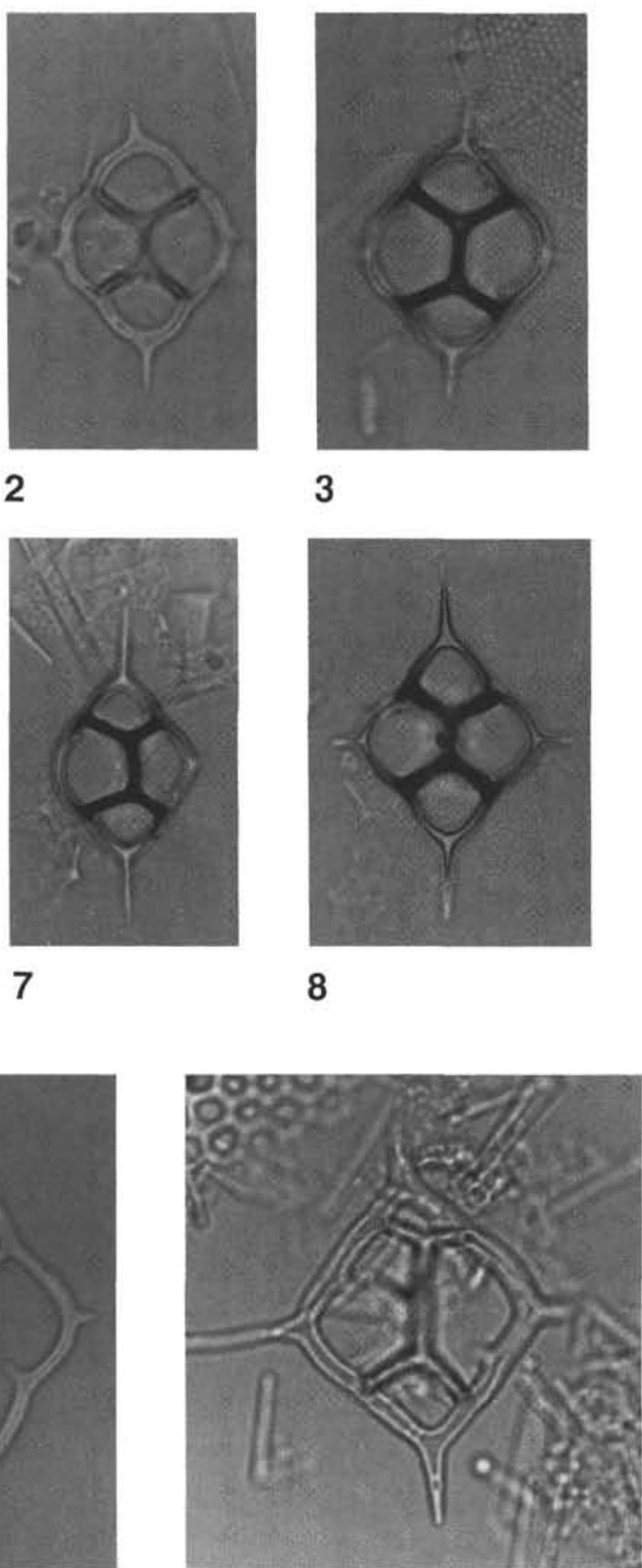

12

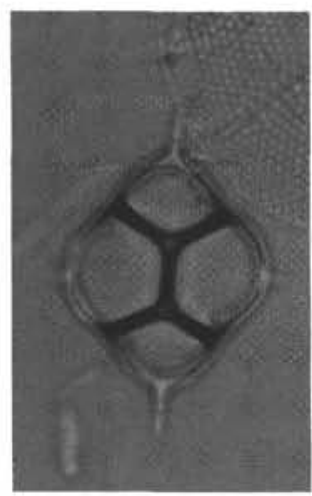

3

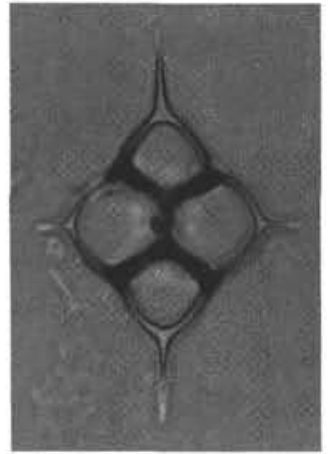

8

9

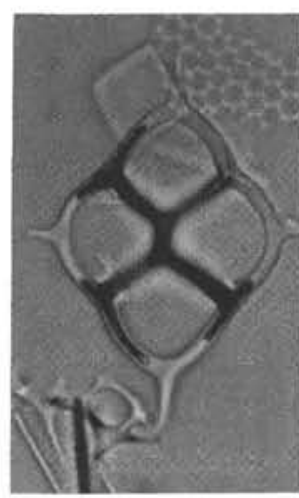

5
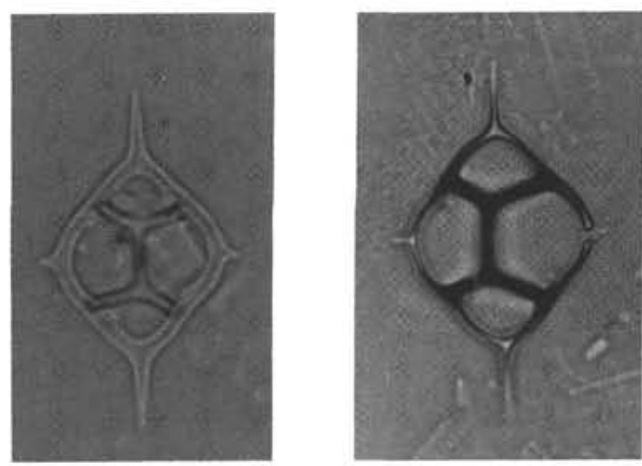

10

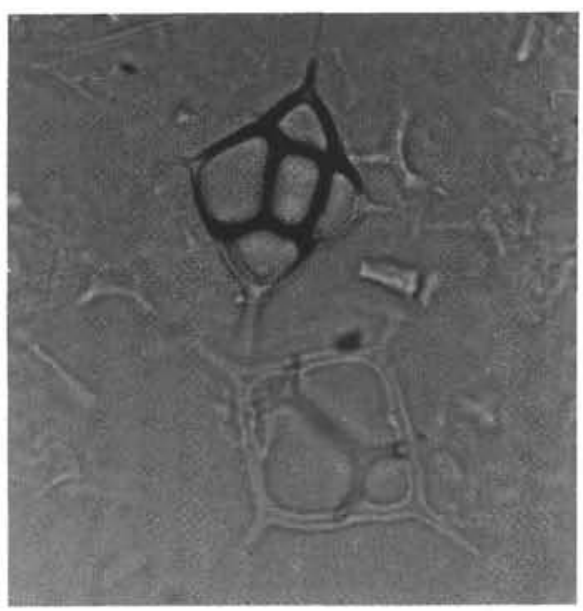

13

Plate 3. Silicoflagellates from Sites 848,850 , and 851 (magnification 850x). 1. Dictyocha varia Locker, Sample 138-851B-10H-1, 120-121 cm. 2-5. Dictyocha extensa extensa Locker (2) Sample 138-848B-6H-1, 120-121 cm; (3) Sample 138-851B-10H-1, 120-121 cm; (4) Sample 138-850B-23X-1, 120-121 cm; (5) Sample 138-850B-26X-1, 120-121 cm. 6-10. Dictyocha sp., Sample 138-848B-4H-4, 120-121 cm. 11. Dictyocha fibula ausonia (Deflandre), Sample 138-851B-11H-1, 120-121 cm. 12, 13. Dictyocha messanensis Haeckel; (12) Sample 138-851B-3H-1, 120-121 cm; (13) Sample 138-848B-4H-4, $120-121 \mathrm{~cm}$ (top specimen is cruxoid). 

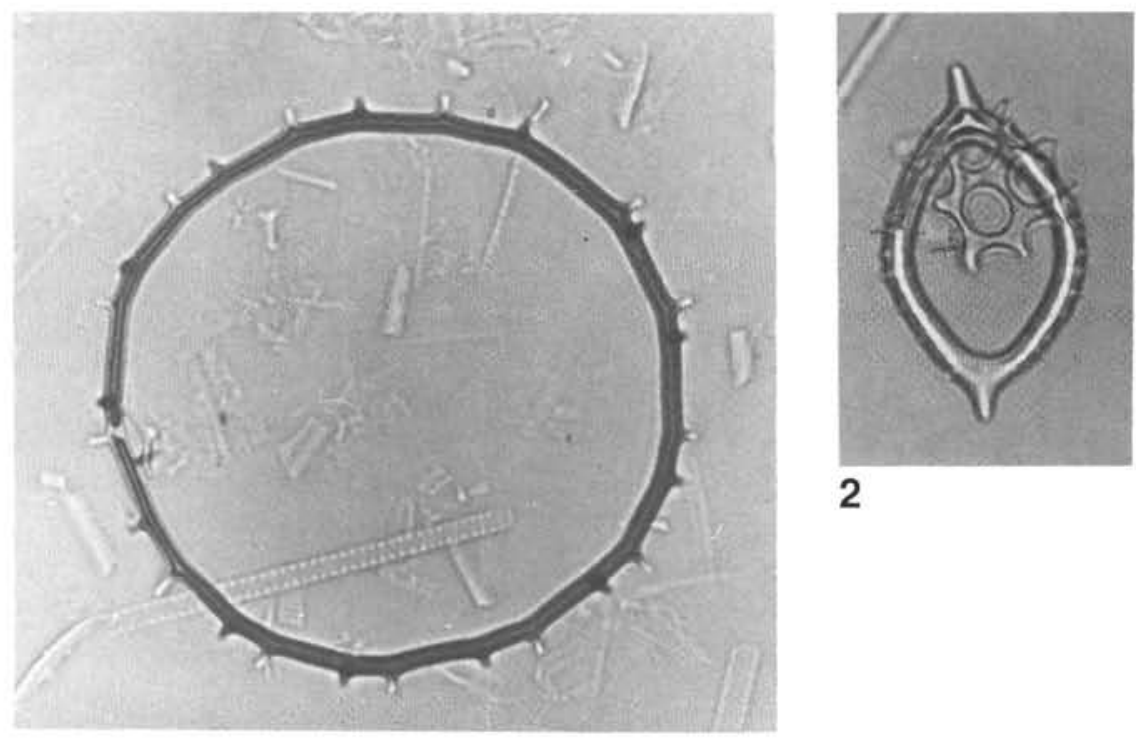

2

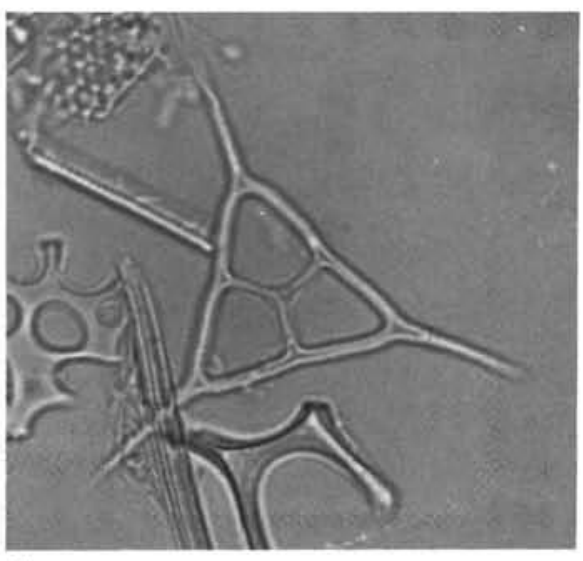

4

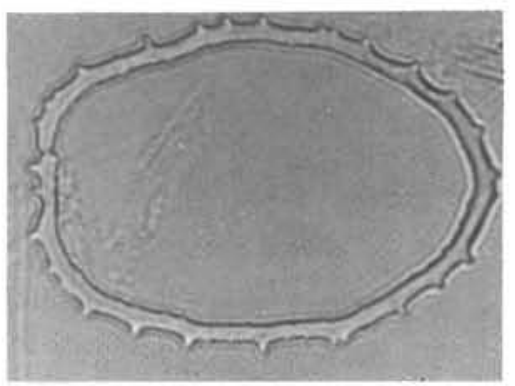

7

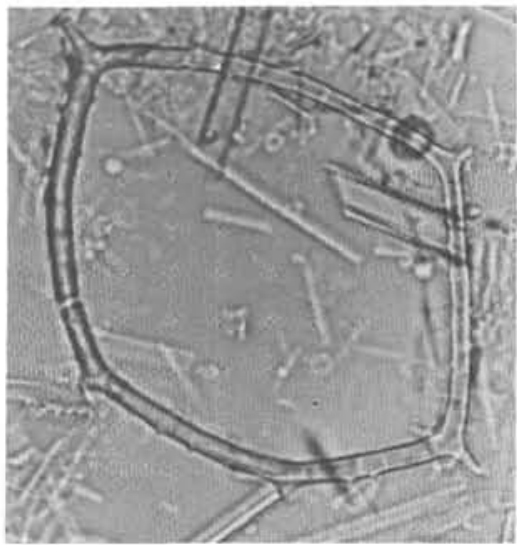

3

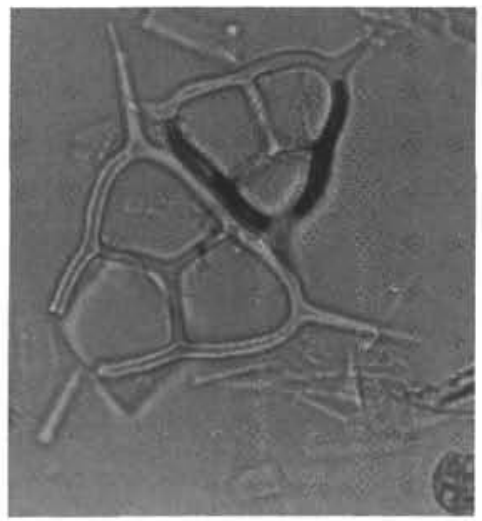

5

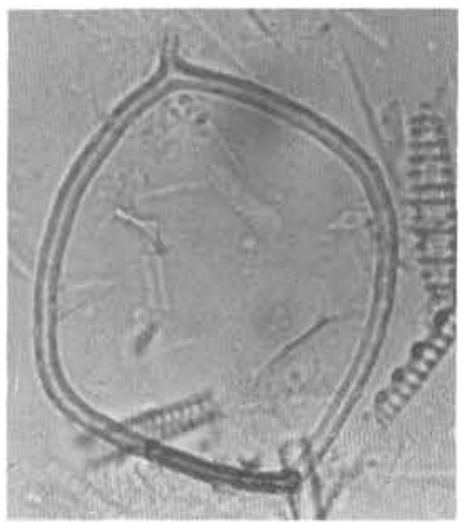

8

Plate 4. Silicoflagellates from Sites 844 and 847 (magnification 850x). 1. Bachmannocena circulus (Ehrenberg), Sample 138-847B-11H-1, 113-114 cm. 2. Bachmannocena diodon nodosa (Ehrenberg), Sample 138-847B-22X-4, 123-124 cm. 3. Bachmannocena quadrangula (Ehrenberg Ex Haeckel), Sample 138-844B-2H-4, 120-121 cm. 4, 5. Corbisema triacantha (Bukry), Sample 138-844B-16H-2, 120-121 cm. 6. Bachmannocena apiculata curvata Bukry, Sample 138-844B-26X-4,120-121 cm. 7. Bachmannocena circulus (Ehrenberg), Sample 138-847B-11H-1, 120-121 cm. 8. Bachmannocena diodon diodon (Ehrenberg) Sample 138-844B-9H-4, 120-121 cm. 

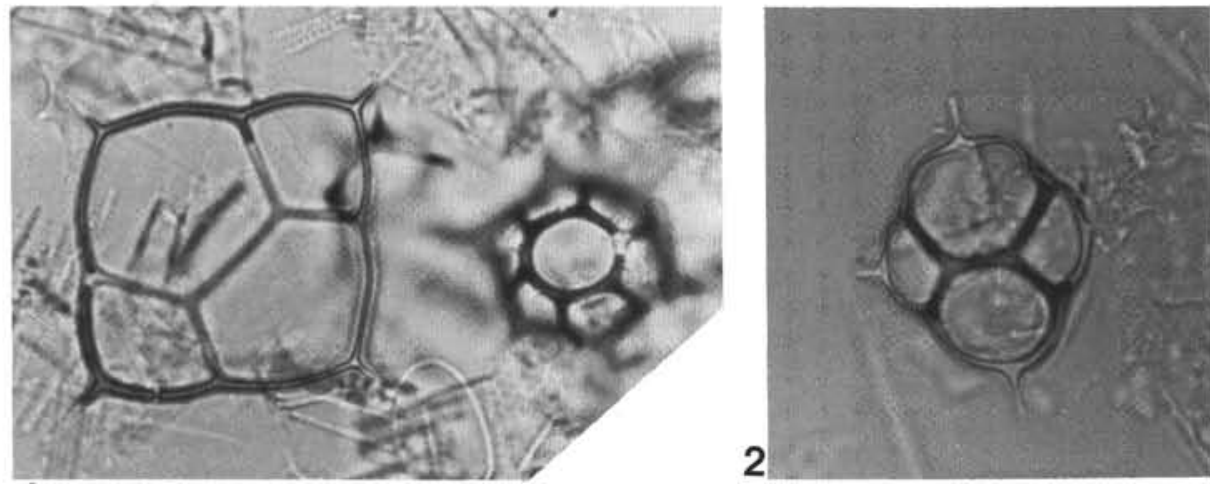

1
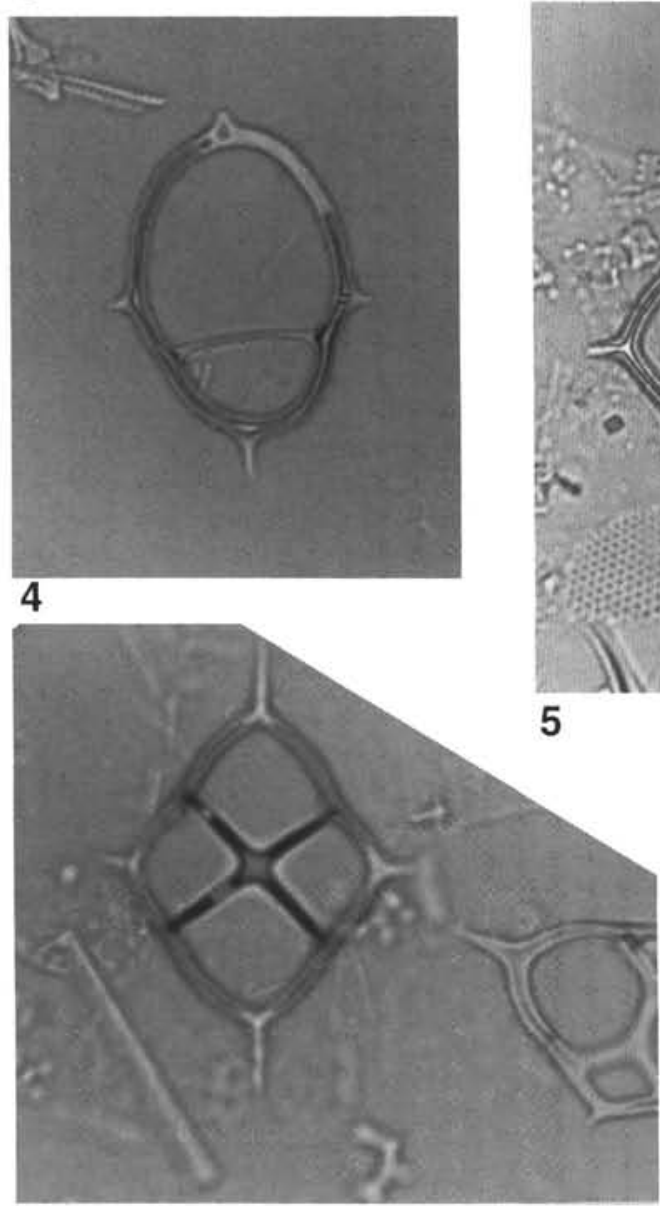

7
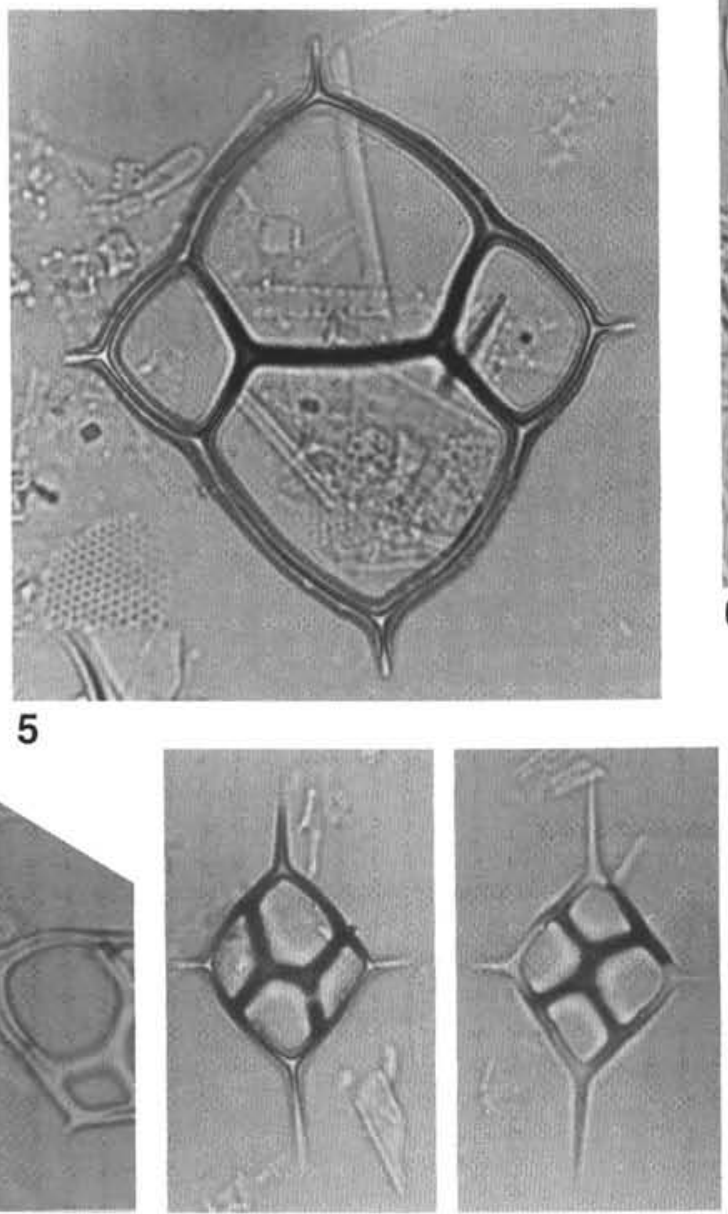

9

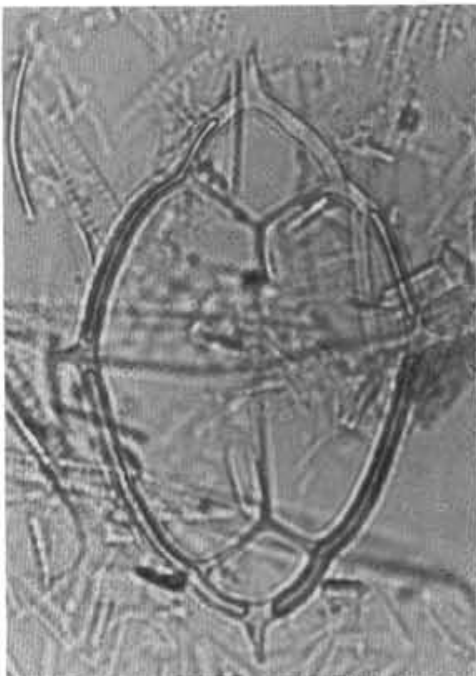

6

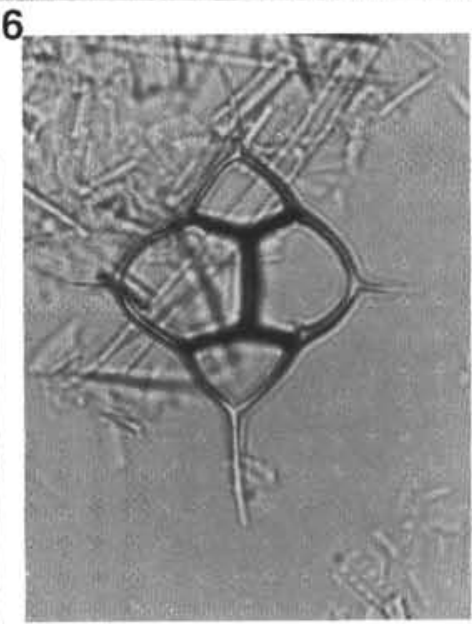

8

10

Plate 5. Silicoflagellates from Sites 844 and 847 (magnification $850 \times$ ). 1. Dictyocha perlaevis (Bukry) (with thin apical elements, left) and Distephanus speculum tenuis Bukry (right), Sample 138-847B-13H-1, 123-124 cm. 2. Dictyocha varia (Locker), Sample 138-844B-31X-1, 92-93 cm. 3. Dictyocha extensa Locker (five-sided), Sample 138-844B-3H-4, 120-121 cm. 4. Dictyocha fibula ausonia (Deflandre) (naviculopsid), Sample 138-844B-31X-5, 92-93 cm. 5. Dictyocha fibula fibula Ehrenberg, Sample 138-847B-17X-1, 123-124 cm. 6. Dictyocha delicata bisecta (Bukry), Sample 138-847B-18X-4, 122-123 $\mathrm{cm}$. 7. Dictyocha extensa extensa f. medusa McCartney, Churchill, and Woestendiek, Sample 138-844B-22X-4, 120-121 cm. 8, 9. Dictyocha subclinata (Bukry); (8) Sample 138-844B-7H-2, 120-121 cm, (9) Sample 138-844B-7H-2, 120-121 cm. 10. Dictyocha extensa longa (Bukry), Sample 138-844B-21X-1, $120-121 \mathrm{~cm}$. 


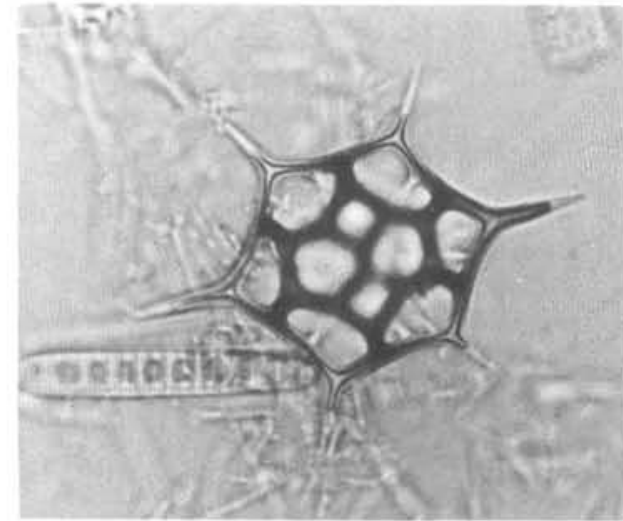

1

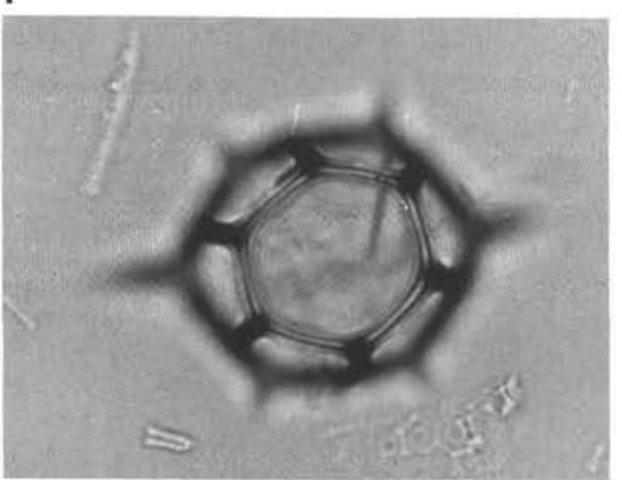

4

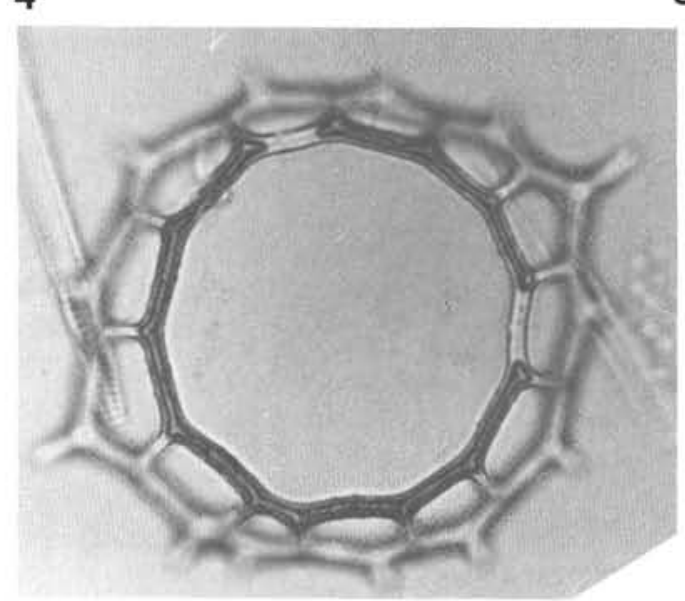

7

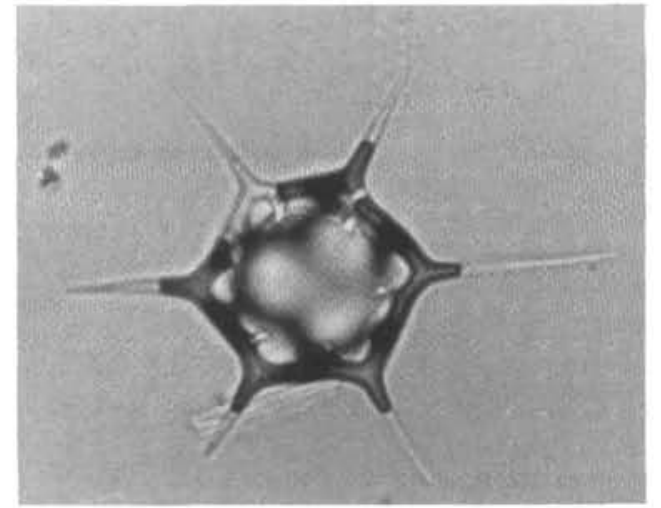

2

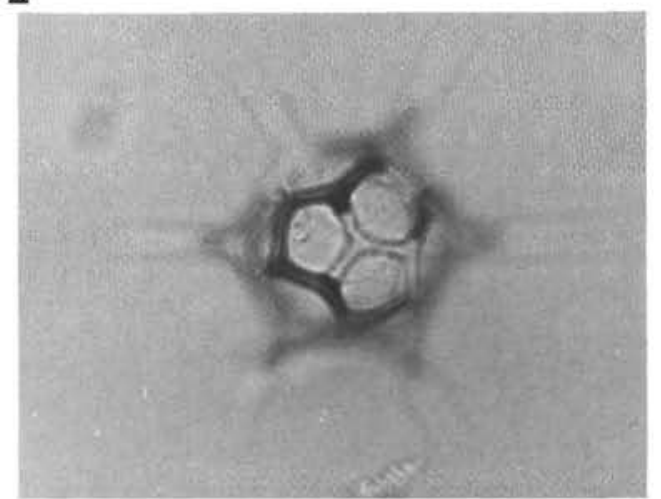

5

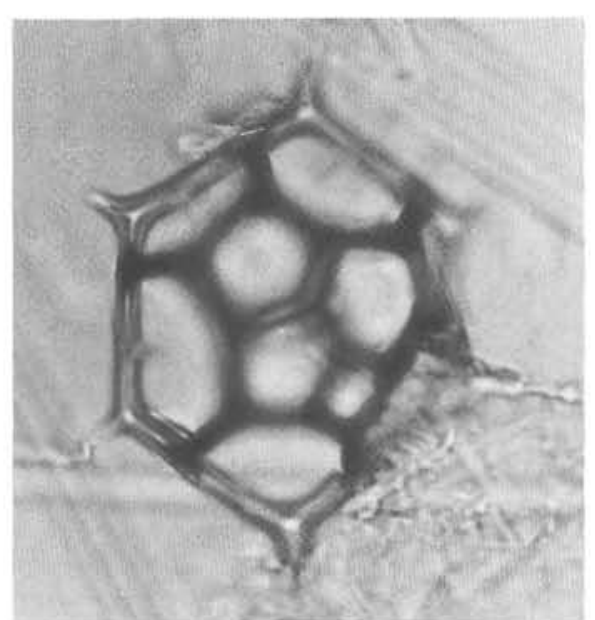

8

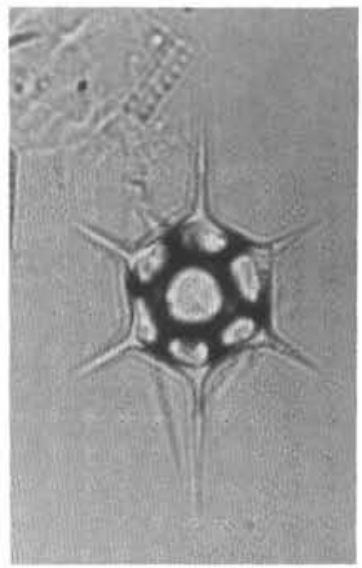

3

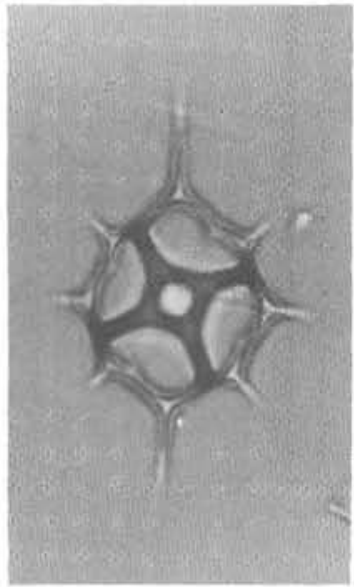

6

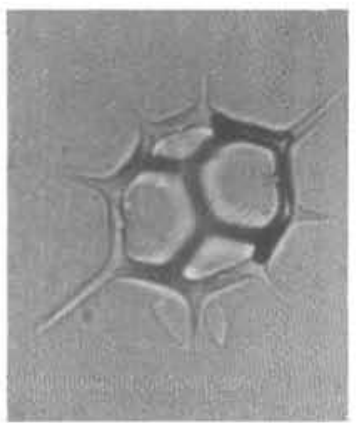

9

Plate 6. Silicoflagellates from Sites 844 and 847 (magnification 850×). 1. Distephanus boliviensis boliviensis (Frenguelli), multiwindowed example; Sample 138-844B-9H-2, 120-121 cm. 2. Distephanus hemisphaericus (Ehrenberg) (multiwindowed) (low focus, high focus of same specimen shown in Fig. 5), Sample 138-848B-6H-1, 120-121 cm. 3. Distephanus speculum speculum Bukry, Sample 138-847B-16X-1, 123-124 cm. 4. Distephanus speculum giganteus Bukry, Sample 138-844B-26X-4, 123-124 cm. 5. Distephanus speculum hemisphaericus Bukry, Sample 138-847B-26X-4, 123-124 cm. 6. Distephanus stauracanthus f. stauracanthus (Ehrenberg), Sample 138-844B-12H-1, 120-121 cm. 7. Distephanus polyactis (Ehrenberg), Sample 138-844B-12H-4, 120-121 cm. 8. Distephanus speculum hemisphaericus Bukry, Sample 138-847B-26X-4, 123-124 cm. 9. Distephanus stauracanthus f. octagonus (Tsumara), Sample 138-844B-15H-2, 120-121 cm. 


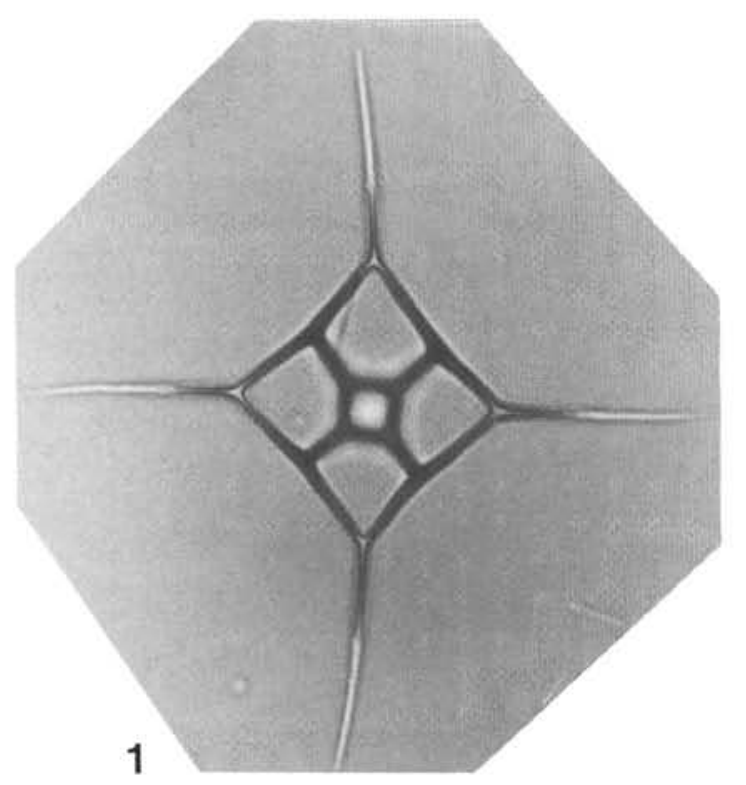

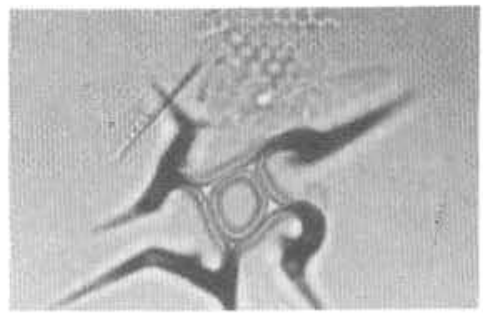

2

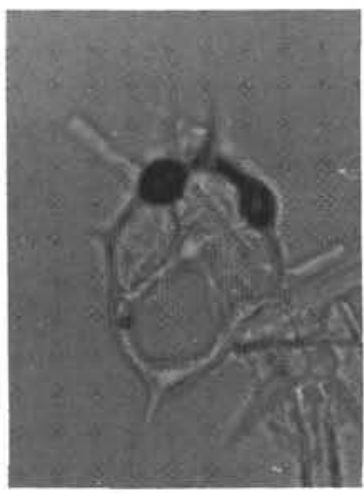

5

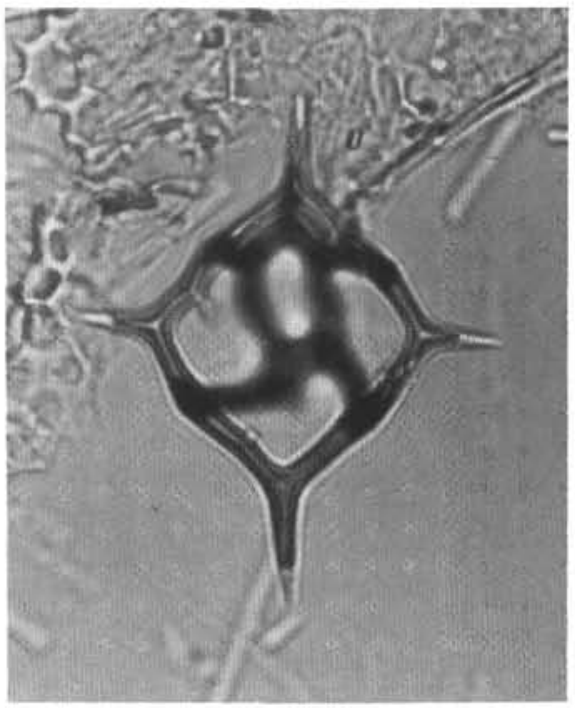

8

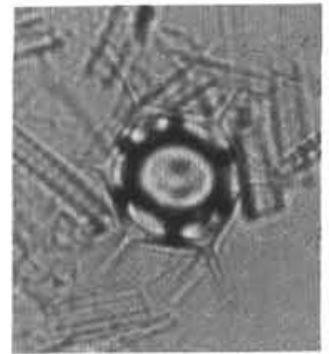

3

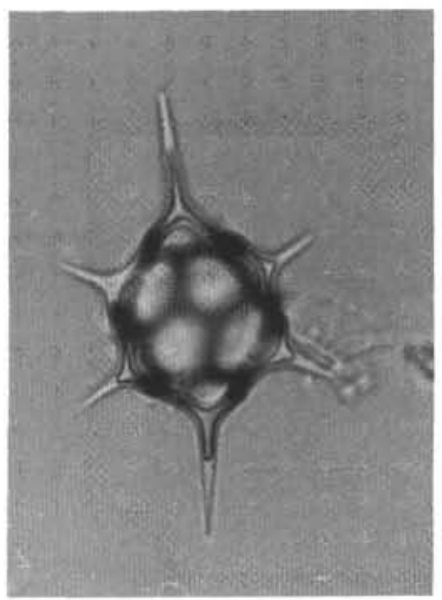

6

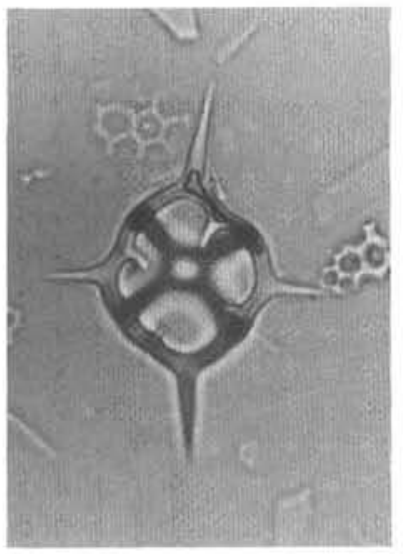

9

Plate 7. Silicoflagellates from Sites 844 and 847 (magnification $850 \times$ ). 1. Distephanus crux crux Ehrenberg, Sample 138-844B-12H-4, 120-121 cm. 2. Distephanus crux crux Ehrenberg (aberrant), Sample 138-844B-12H-4, 120-121 cm. 3. Distephanus speculum minutus (Bachmann), Sample 138-847B-18X-1, 123-124 cm. 4. Distephanus speculum pentagonus Lemmermann, Sample 138-844B-7H-2, 120-121 cm. 5. Distephanus crux crux Ehrenberg (aberrant), Sample 138-844B-28X-4, 120-121 cm. 6. Distephanus speculum hemisphaericus (Ehrenberg), Sample 138-844B-18H-4, 120-121 cm. 7. Distephanus speculum speculum (Ehrenberg), Sample 138-847B-15X-1, 120-121 cm. 8, 9. Distephanus crux crux Ehrenberg; (8) aberrant, Sample 138-847B-16X-1, 123-124 cm, (9) Sample 138-844B-16H-4, 120-121 cm. 


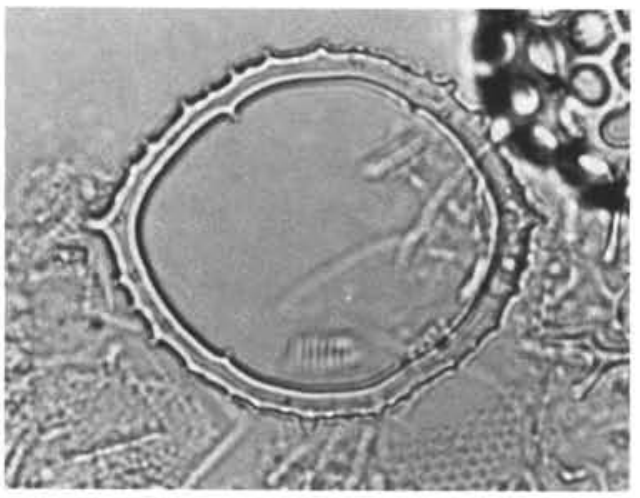

1

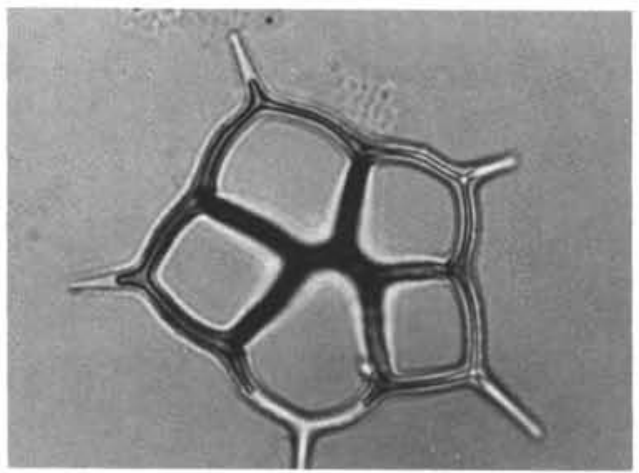

4

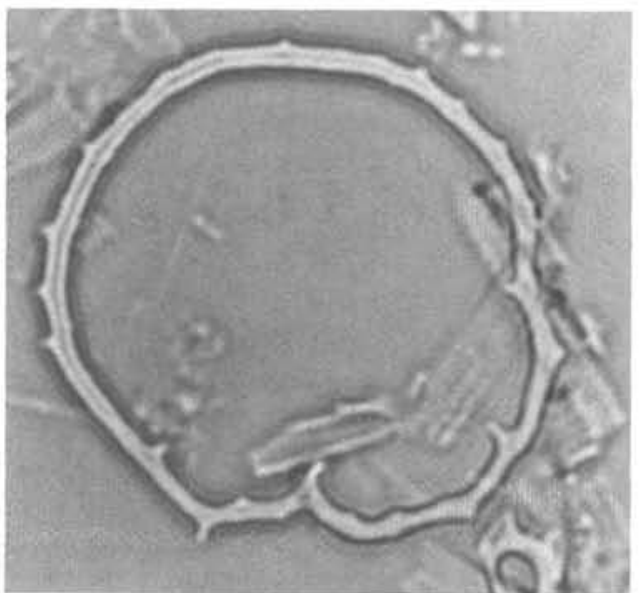

7

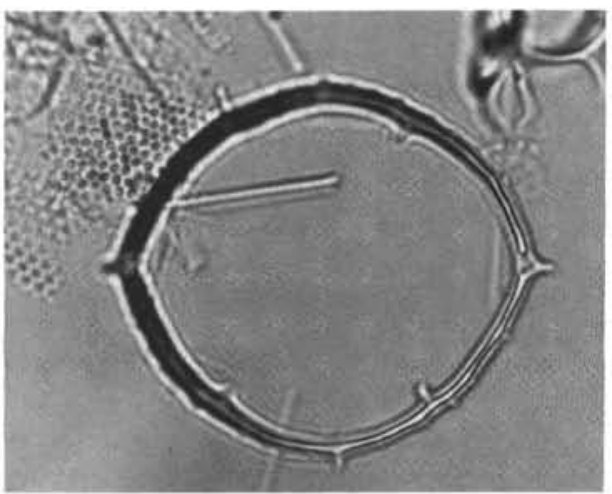

2

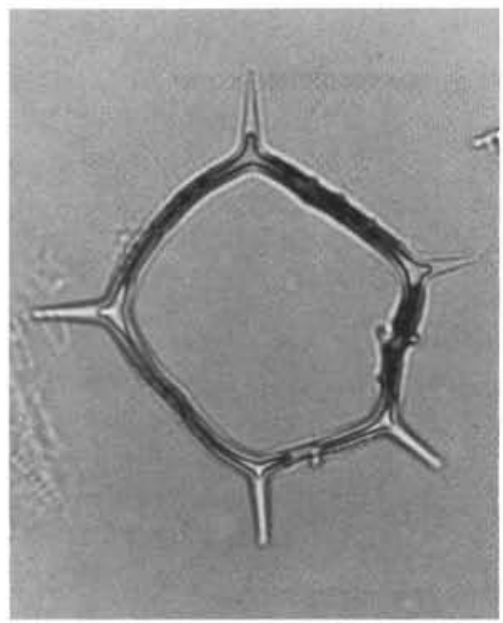

5

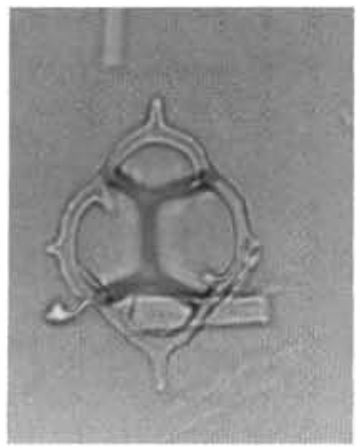

8

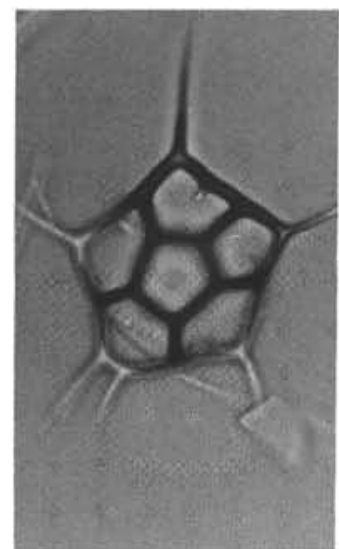

3

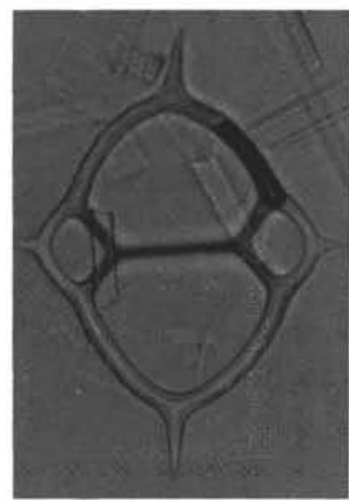

6

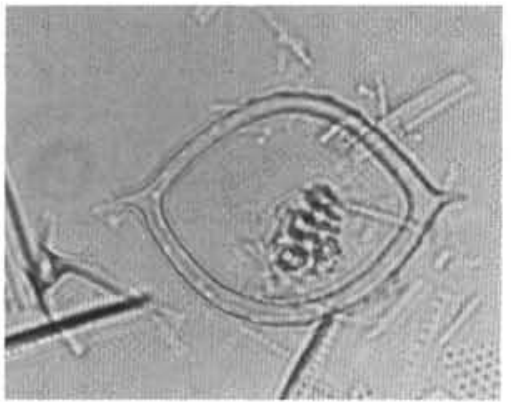

9

Plate 8. Silicoflagellates from Site 849 (magnification 850x). 1, 2. Bachmannocena diodon nodosa (Bukry), Sample 138-849B-20X-1, 120-121 cm. 3. Distephanus quinquangellus Bukry and Foster, Sample 138-849B-3H-4, 120-121 cm. 4. Dictyocha perlaevis perlaevis Frenguelli (five-sided), Sample 138-849B-4H-1, 120-121 cm. 5. Bachmannocena quadrangula Ehrenberg, Sample 138-848B-4H-1, 120-121 cm. 6. Dictyocha varia Locker, Sample 138-852B-8H-1, 120-121 cm. 7. Bachmannocena circulus (Ehrenberg), Sample 138-849B-15X-1, 120-121 cm. 8. Dictyocha extensa extensa Locker, Sample 138-849B-17X-1, 120-121 cm. 9. Bachmannocena diodon nodosa (Bukry), Sample 138-849B-3H-1, 120-121 cm. 


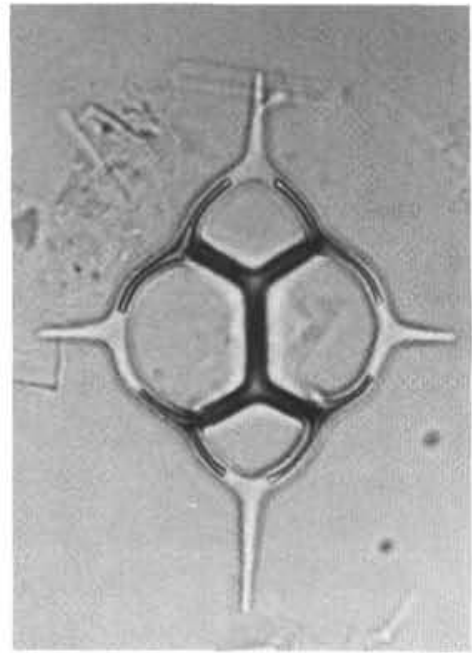

1

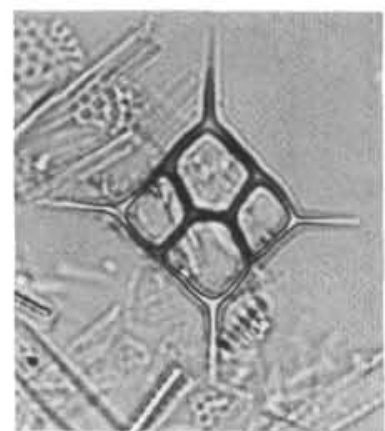

4

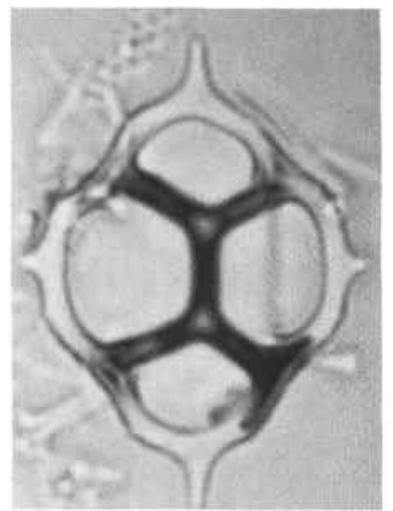

6

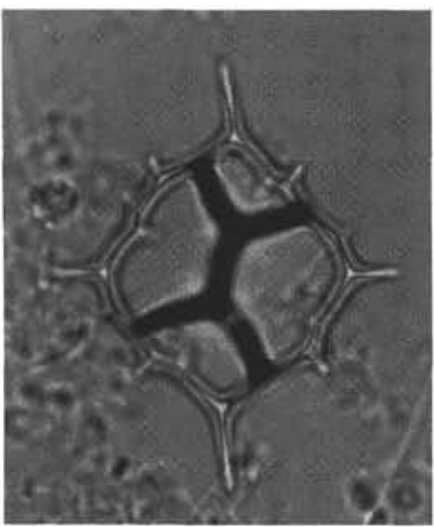

2

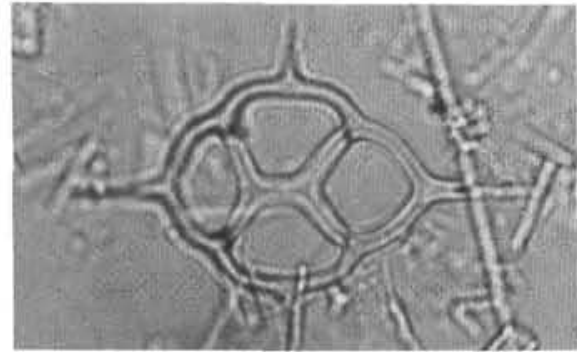

5

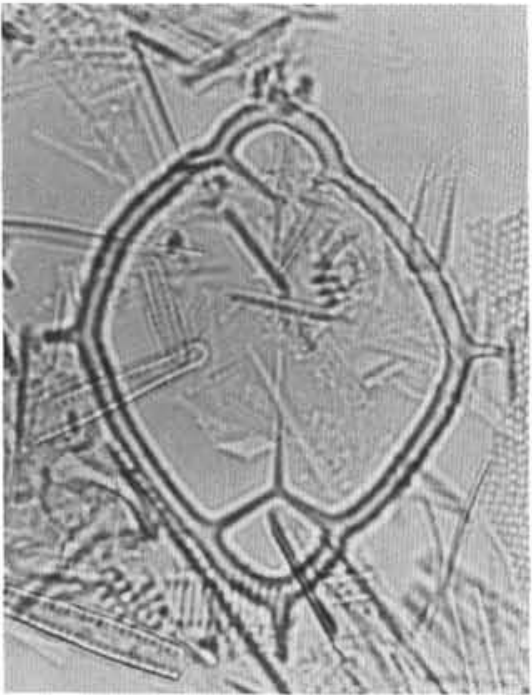

7

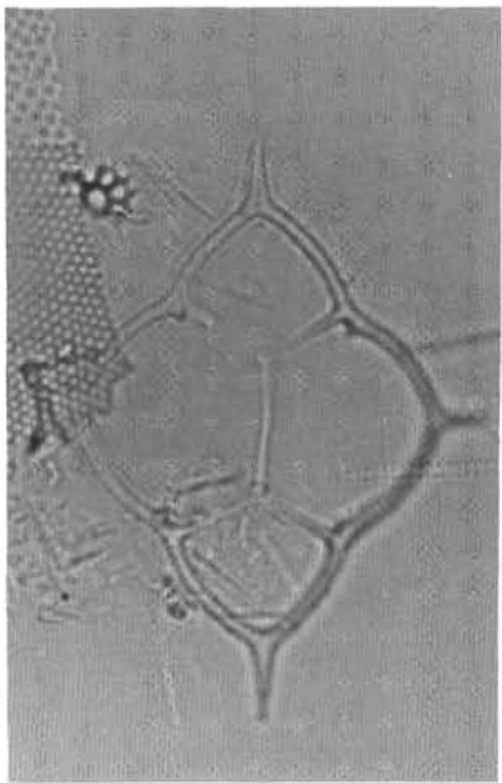

3

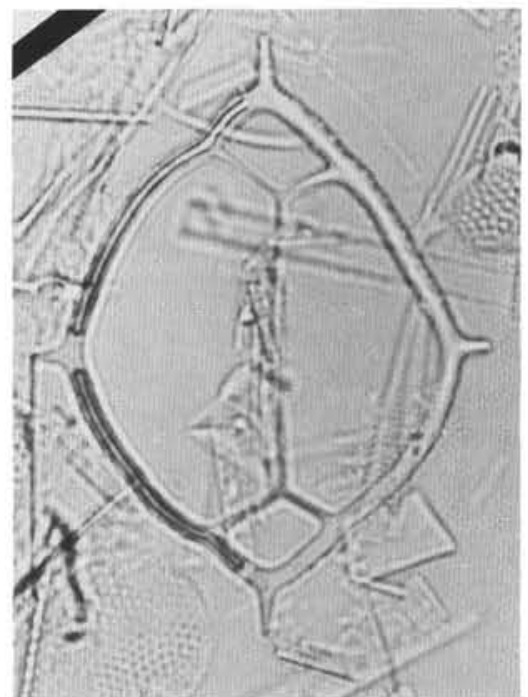

8

Plate 9. Silicoflagellates from Site 849 (magnification $850 \times$ ). 1. Dictyocha calida ampliata Bukry, Sample 138-849B-8H-1, 120-121 cm. 2. Dictyocha aculeata aculeata Lemmermann, Sample 138-849B-1H-1, 120-121 cm. 3. Dictyocha perlaevis perlaevis Frenguelli (thin apical elements), Sample 138-849B6H-1,120-121 cm. 4. Dictyocha clinata (Bukry), Sample 138-849B-20X-1, 120-121 cm. 5. Dictyocha angulata Bukry, Sample 138-849B-15X-1, 120-121 cm. 6. Dictyocha perlaevis ornata Bukry, Sample 138-849B-15X-1, 120-121 cm. 7, 8. Dictyocha bisecta delicata Bukry, Sample 138-849B-16X-1, 120-121 cm. 


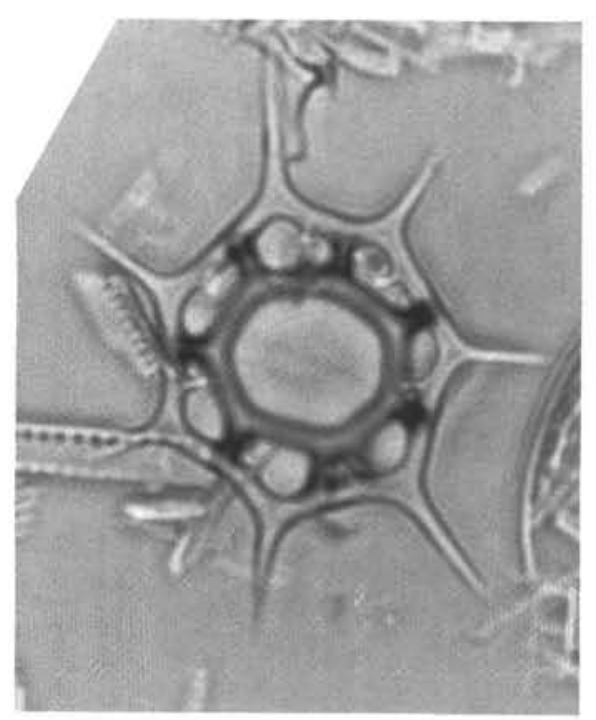

1

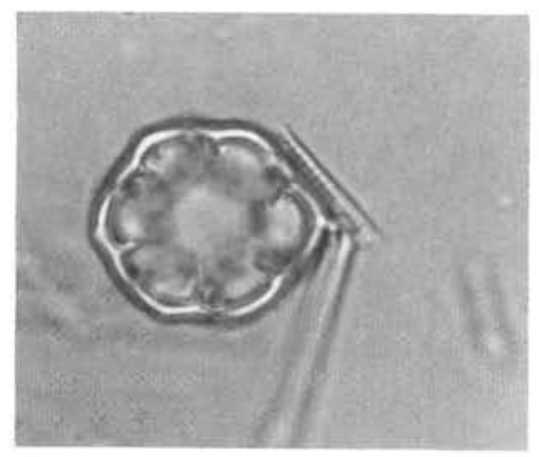

4

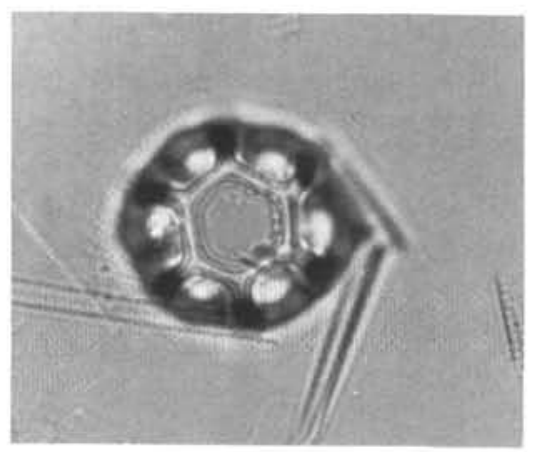

7

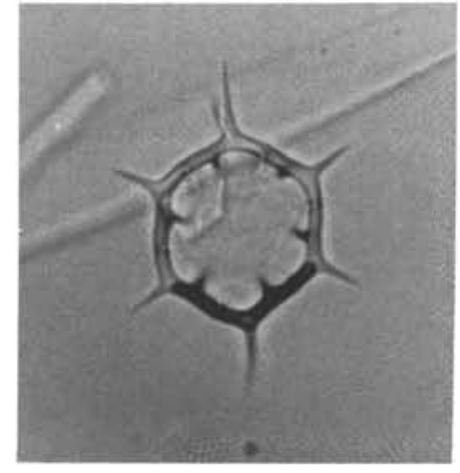

2

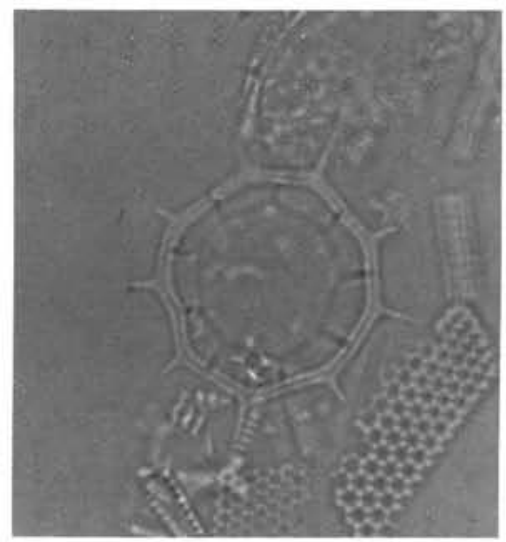

5

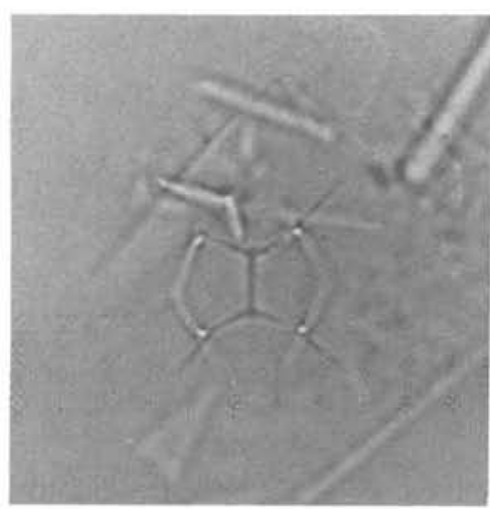

8

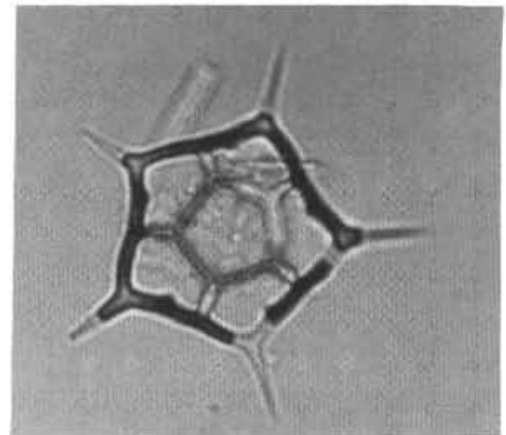

3

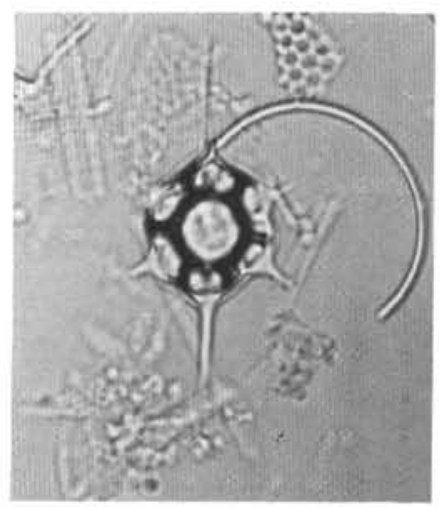

6

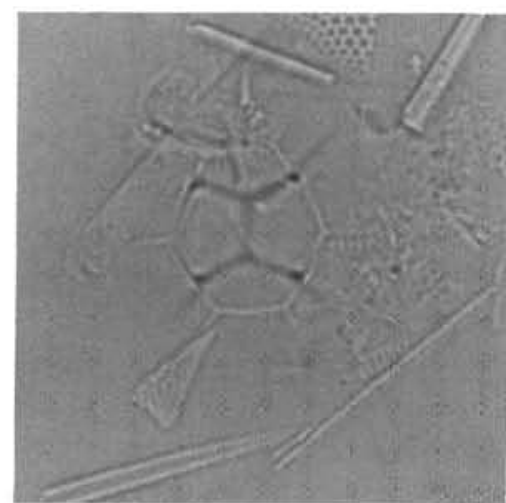

9

Plate 10. Silicoflagellates from Site 849 (magnification $850 \times$ ). 1. Distephanus boliviensis (Frenguelli), Sample 138-849B-25X-1, 120-121 cm. 2. Distephanus speculum tenuis Bukry, Sample 138-849B-27X-1, 120-121 cm. 3. Distephanus quinquangellus Bukry and Foster, Sample 138-849B-8H-1, 120-121 cm. 4, 5. Distephanus xenus Bukry, Sample 138-849B-20X-1, 120-121 cm; (4) basal ring in focus, (5) apical ring in focus; 6. Distephanus pulchra (Schiller), Sample 138-849B-2H-1, 120-121 cm. 7. Distephanus speculum speculum (Ehrenberg), Sample 138-849B-15X-1, 120-121 cm. 8,9. Unidentified silicoflagellate (or radiolarian fragment?), Sample 138-849B-3H-4, 120-121 cm; (8) high focus, (9) low focus. 